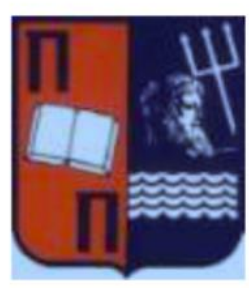

UNIVERSITY OF PIRAEUS

SCHOOL OF ECONOMICS, BUSINESS AND INTERNATIONAL STUDIES

DEPARTMENT OF ECONOMICS

\title{
Essays in Business Strategy, Sustainability and Innovation
}

\author{
Ph.D. Thesis \\ Maria Giaka \\ A DISSERTATION SUBMITTED \\ TO THE DEPARTMENT OF ECONOMICS \\ OF UNIVERSITY OF PIRAEUS \\ IN PARTIAL FULFILLMENT OF THE REQUIREMENTS FOR THE \\ DEGREE OF DOCTOR OF PHILOSOPHY
}

Piraeus, 2020 



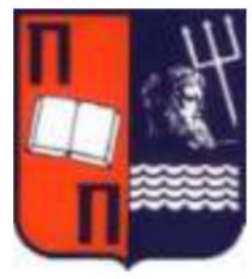

ПАNЕПІ $Г$ THМIO ПЕIPAIA

$\Sigma$ XO $\Lambda$ H OIKONOMIK $\Omega$ N, EПIXEIPHMATIK $\Omega N$ KAI $\Delta$ IE $\Theta N \Omega N \Sigma \Pi O Y \Delta \Omega N$

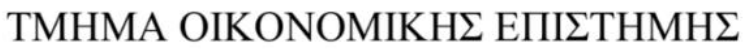

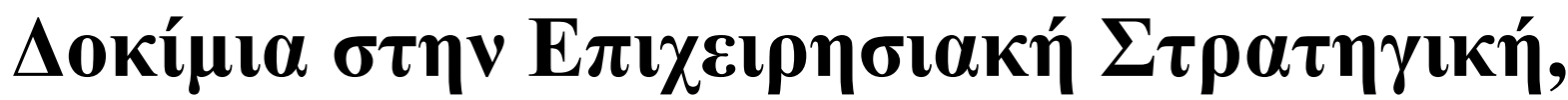

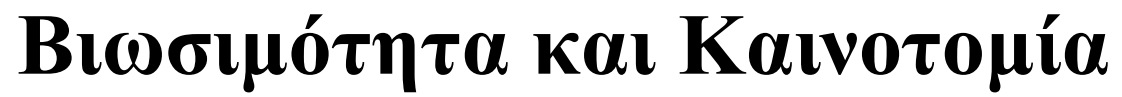

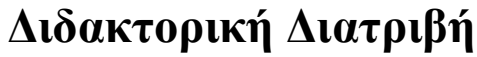

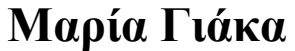 \\ H $\triangle$ IATPIBH YПOBA $\Lambda$ ЕTAI

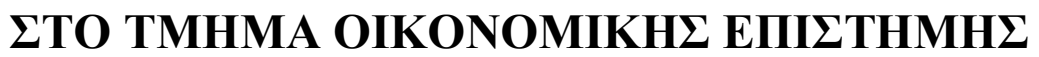

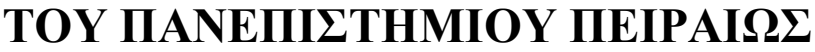

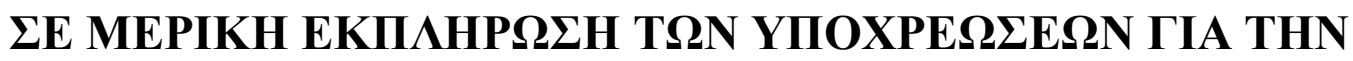

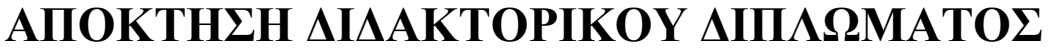

Пeıрaıós, 2020 



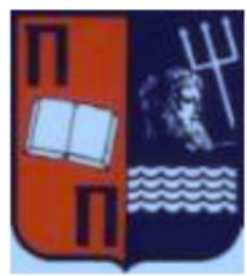

UNIVERSITY OF PIRAEUS

SCHOOL OF ECONOMICS, BUSINESS AND INTERNATIONAL STUDIES

DEPARTMENT OF ECONOMICS

\title{
Essays in Business Strategy, Sustainability and Innovation
}

\author{
Ph.D. Thesis \\ Maria Giaka
}

Supervisor: Irene Fafaliou

Professor of Economics

Piraeus, 2020 



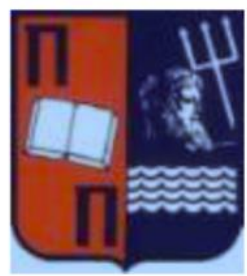

UNIVERSITY OF PIRAEUS

SCHOOL OF ECONOMICS, BUSINESS AND INTERNATIONAL STUDIES

DEPARTMENT OF ECONOMICS

\title{
Essays in Business Strategy, Sustainability and Innovation
}

\author{
Ph.D. Thesis \\ Maria Giaka
}

\author{
Defense Committee \\ Professor Irene Fafaliou \\ Professor Demetrius Yannelis \\ Associate Professor Michael Polemis \\ Professor Sotiris Karkalakos \\ Professor Claire Economidou \\ Assistant Professor Markos Tselekounis \\ Professor Emmanouil Tsiritakis
}

Piraeus, 2020 

I would like to dedicate this thesis to those who believe in me and support me until the end... 



\section{Acknowledgments}

First and foremost, I would like to express my deepest gratitude to my supervisor Professor Irene Fafaliou, who has been an excellent mentor for me. I would like to thank her for her generous advice, patience and guidance throughout the planning and development of the research process in this thesis. I appreciate all her contributions in time, ideas, and facilities to make my Ph.D. experience productive and stimulating. Her constant support was precious for me; without her, this thesis would not have been possible.

Besides my advisor, I would also like to thank Associate Professor Michael Polemis, for his support through the whole process and for sharing his groundbreaking ideas and technical skills. I have appreciated his collaboration and his impressive willingness to participate in this research study.

Moreover, for this thesis, I would like to thank my committee members: Professor Demetrius Yannelis, Professor Emmanouil Tsiritakis, Professor Sotiris Karkalakos, Professor Claire Economidou, and Assistant Professor Markos Tselekounis for their time, interest, and helpful comments. I would also like to thank the other members of my oral defense committee for their insightful questions and encouragement. I take this opportunity to express my gratitude to all of the Department of Economics faculty members for their help and support. My special thanks to Professor Claire Economidou and Professor Emmanouil Tsiritakis for their time, guidance, ideas and support.

My sincere thanks also go to Konstantina Louloudi, Elpiniki Fampiou, Panagiotis Psyllos, Sofia Xesfingi, Dimitris Karamanis, Alexandros Bechlioulis, Konstantinos Dellis, Vasileios Katavelis, Ioanna Tsantili and Froso Katsi who provided me with the opportunity to be a member of a devoted and hard-working team. I am grateful for their support but also for all the fun we have had these years. My time at the University of Piraeus was made enjoyable in large part due to them. I consider them friends and part of my life and there are no words to describe how much I appreciate them.

I am deeply thankful to my family for all their love, tolerance and encouragement; my mother Zoi, my father Simeon, my sister Anna, my grandmother Anna and my grandfather Nikolaos who have provided me with moral and emotional support throughout my life. I owe everything to them and 
I am really happy and grateful I have them in my life. My special appreciation to my grandfather Nikolaos, as he is responsible for who I am today and what I have accomplished. I wouldn't have made it this far if it hadn't been for you. Thank you for everything.

I would also like to express my gratitude to all my close friends: Maria Kotti, Sofia Ravani, Roubini Vasileiou, Maria Boulou, Nikoletta Stamatiou, Vayia Stamati and Nickolas Theodoridis for their support and understanding during the whole process. My special gratitude to my bestie Maria Kotti for her being in my life. Thank you for showing me that friends are the family we choose for ourselves.

And most of all, I owe my deepest gratitude to my life partner, Dimitris Konstantios, for his affection, encouragement, understanding and patience. He supported me without any complaint or regret, making it easier for me to complete my Ph.D. thesis. Thank you for always being by my side.

Maria Giaka

Piraeus, 2020 


\begin{abstract}
The topic of the present Ph.D. thesis is the investigation of the importance of corporate sustainability and innovation strategies adopted by modern companies and in particular by a large sample of US-listed companies. Specifically, the thesis consists of three independent essays. The first one focuses on a critical discussion of key areas of academic research on corporate sustainability and its theoretical implications on business prosperity. The second essay, which provides empirical evidence on the matter, examines and evaluates the impact of different aspects of innovation on corporate sustainability in quantitative terms; the third one investigates whether corporate sustainable performance is related to business longevity in the market.
\end{abstract}

The first essay, which is presented in Chapter 2, examines the literature on corporate sustainability and analyzes its evolution over time as part of the business strategy of modern companies as well as its implications. In particular, the first essay is based on a large number of valid secondary studies to highlight the similarities and differences of the research in the field, but mainly to identify the limitations of the existing research efforts. The Socially Responsible Investment (SRI) concept as well as the Environmental, Social and Governance (ESG) principles are clarified through the exploration of the historical evolution of the corporate sustainability concept. Moreover, the thesis analyzes the ESG criteria and how their integration on firms' strategies can create a competitive advantage.

The second essay, which is presented in Chapter 3, explores the relationship between corporate sustainability and innovation. In order to attain this goal, various aspects of innovation as well as the ESG as a risk mitigation tool, are conceptualized and checked. For this empirical research, a unique micro-level panel dataset consisting of 1.048 firms scattered across the USA, over the period 2007-2016, has been constructed. The findings, based on several advanced statistical tests and econometric models, are robust and reveal that the key mechanism for achieving corporate sustainability is through an innovation channel.

The third essay, which is presented in Chapter 4, explores the relationship between corporate sustainable performance and firms' longevity in the market. This empirical analysis uses a set of 
data from 1.585 USA companies, over the period 2007-2016. Based on survival analysis estimations, the findings suggest that companies with higher sustainable performance are more likely to remain listed on the stock market for longer periods and therefore serve better their investors.

Finally, Chapter 5, based on the findings derived from the theoretical investigation in Chapter 2 and the quantitative research in Chapters 3 and 4, presents and discusses the main conclusions on business strategies, sustainability and innovation. It also describes the fundamental contributions of the present thesis and offers suggestions for future research on corporate sustainability. 


\section{Пєрі́ $\eta \psi \eta$}

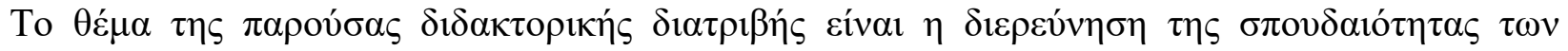

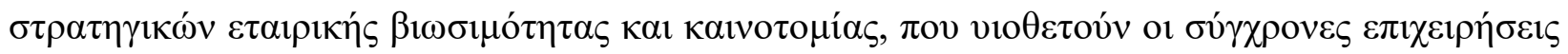

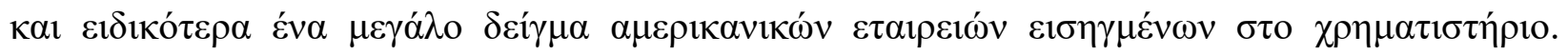

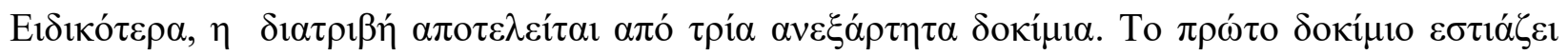

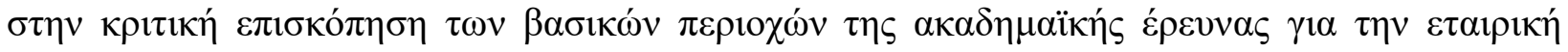

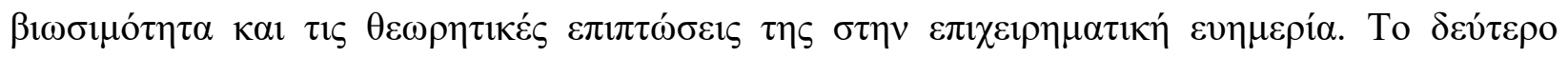

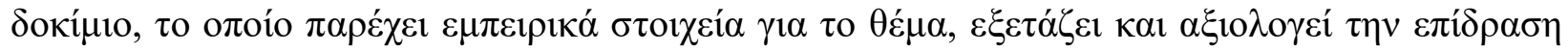

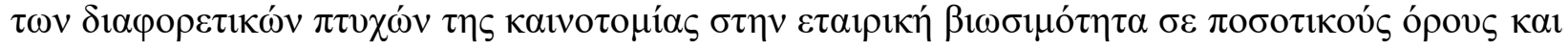

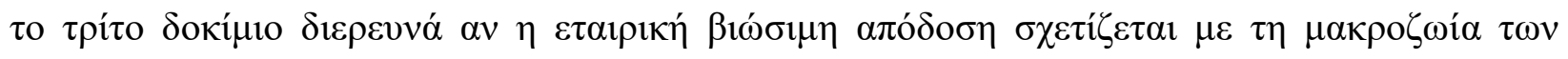

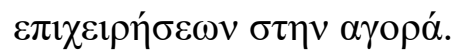

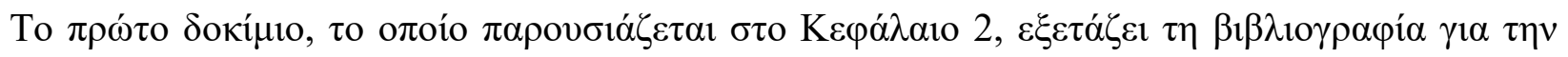

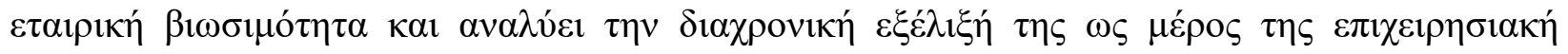

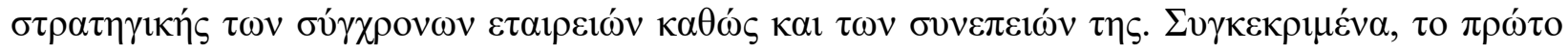

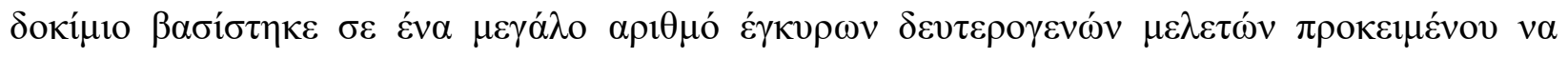

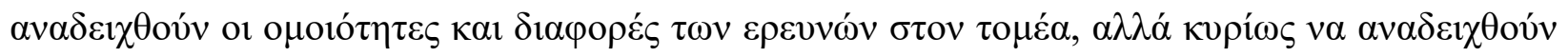

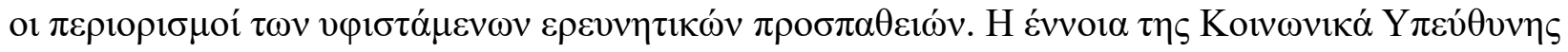

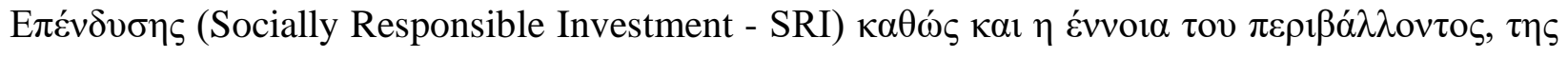

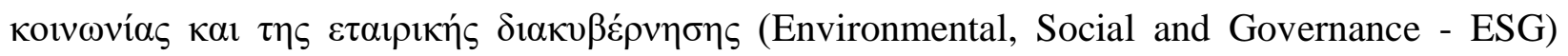

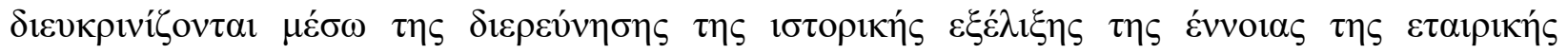

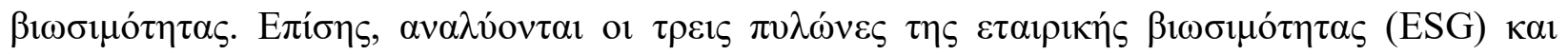

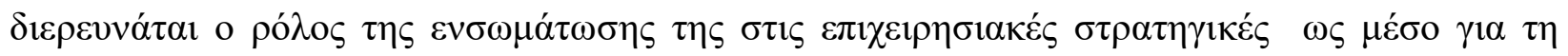

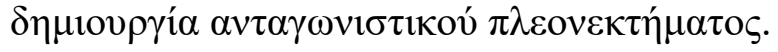

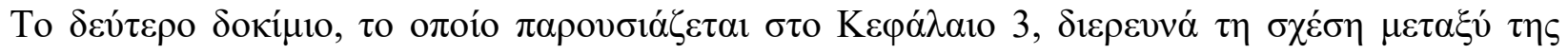

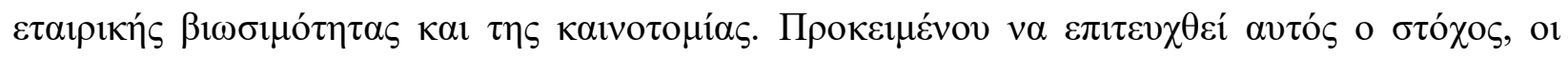
$\delta$ ió

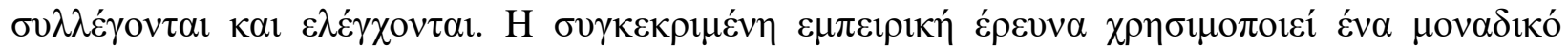

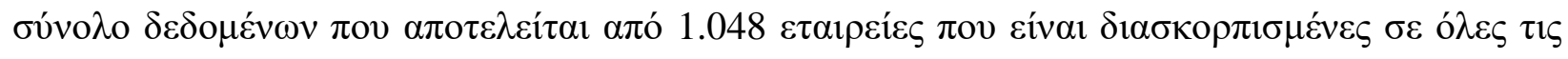

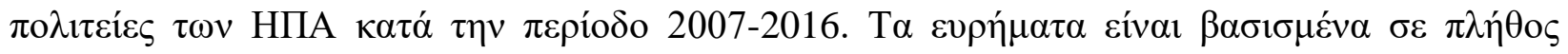

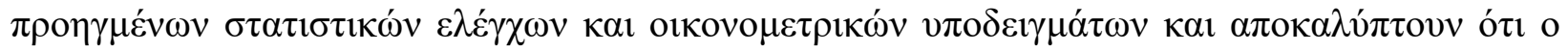




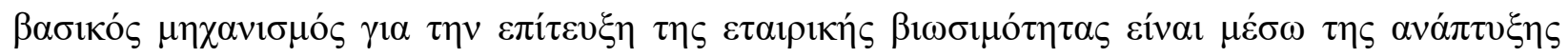

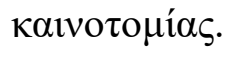

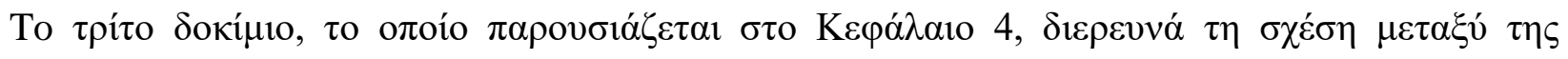

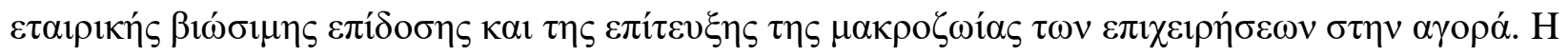

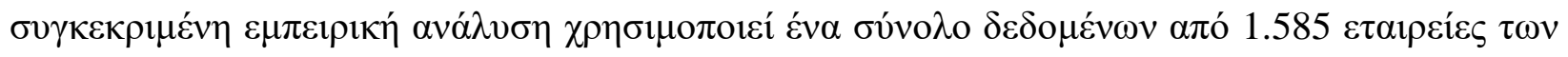

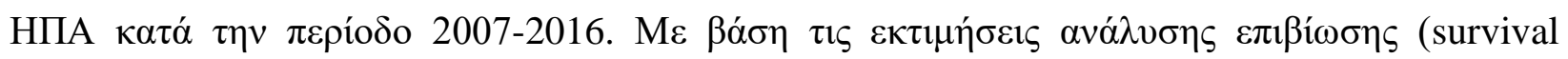

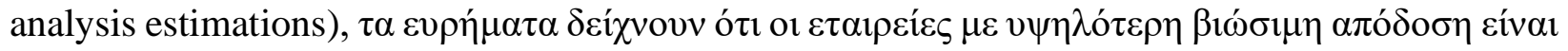

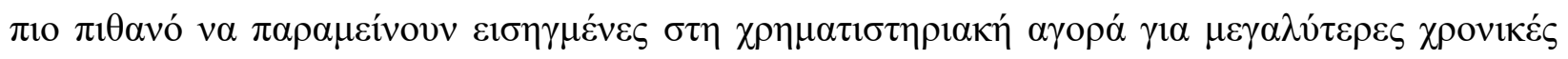

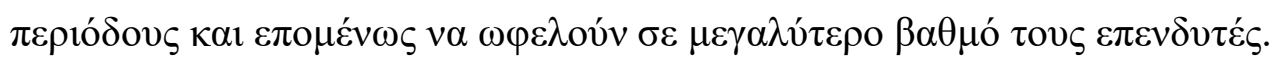

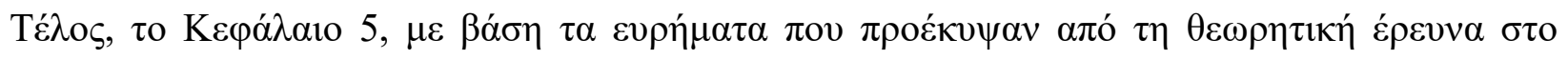

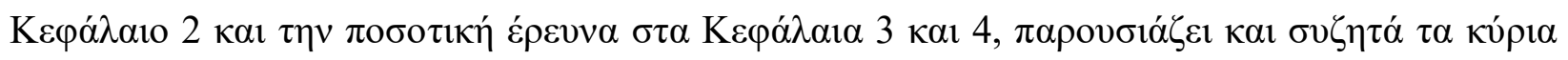

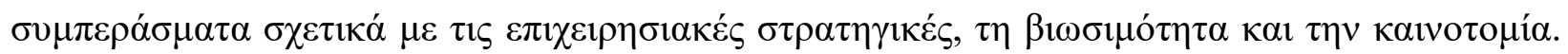

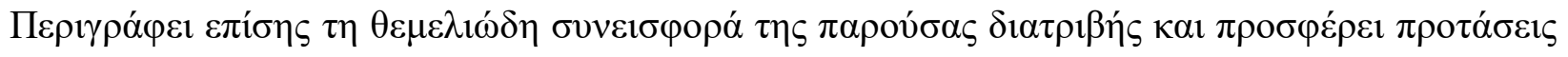

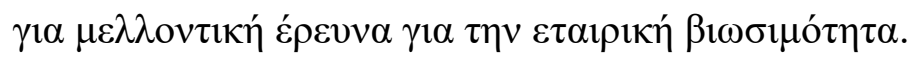




\section{List of Contents}

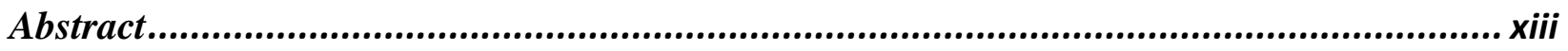

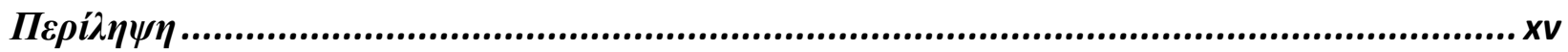

List of Contents .................................................................................. xvii

List of Figures ....................................................................................

List of Tables ...........................................................................................

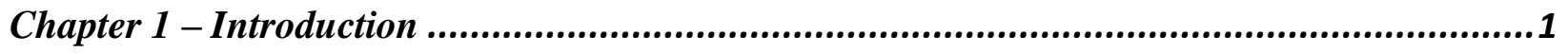

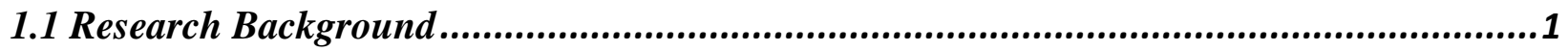

1.2 Research Motivation and Contribution of the thesis................................................4

1.3 Research Questions and Methodology employed ...................................................7

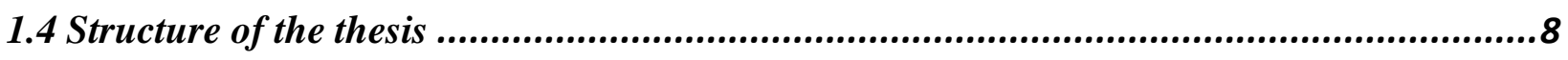

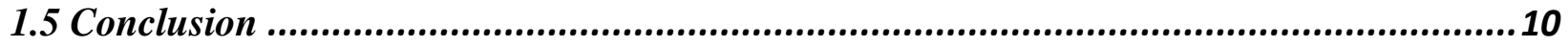

Chapter 2 - Discussion of the literature on corporate sustainability as a business strategy ....11

2.1 Introduction ...................................................................................... 11

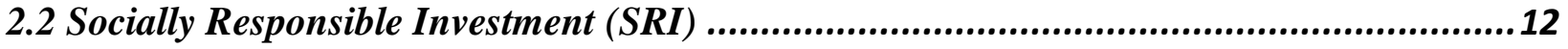

2.2.1 History of Socially Responsible Investment..........................................................................16

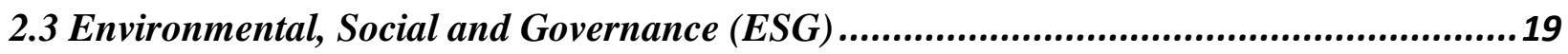

2.4 Why integrate ESG into a business strategy ........................................................30

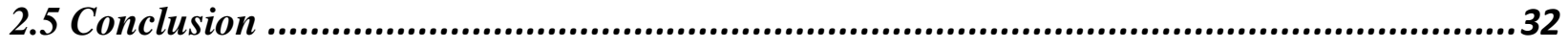

Chapter 3 - Corporate sustainability performance and Innovation: A firm-level analysis for

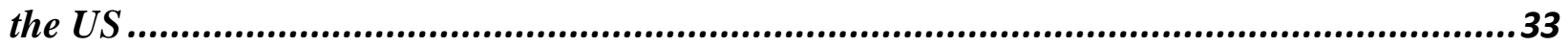

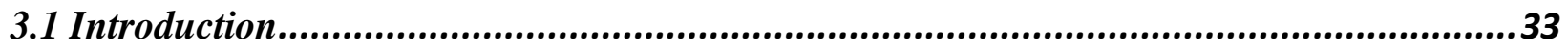

3.2 Related literature and Hypotheses Development ..................................................35

3.2.1 Environmental, social, and governance framework...........................................................35

3.2.2 The multi-dimensional nature of innovation................................................................37

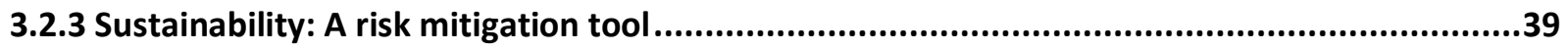

3.2.4 Innovation and sustainability nexus ...............................................................................40

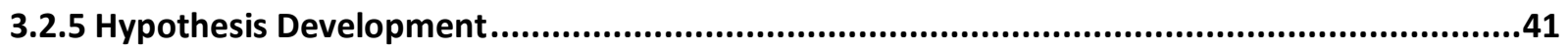

3.3 Data and sample variables......................................................................43

3.4 Estimation strategy and methodology .......................................................45 


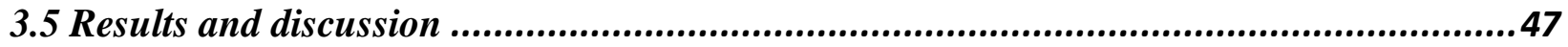

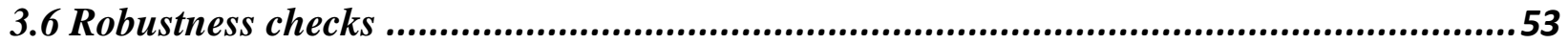

3.6.1. Instrumental Analysis .........................................................................................................5

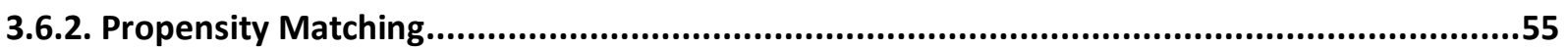

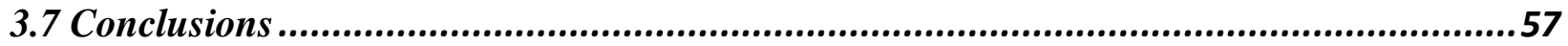

Chapter 4-Firms' Sustainability Performance and Market Longevity: A firm-level analysis

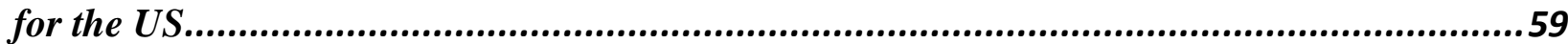

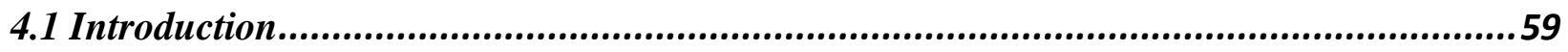

4.2 Related literature and Hypotheses Development ...........................................................61

4.2.1 Literature Review ...............................................................................................................61

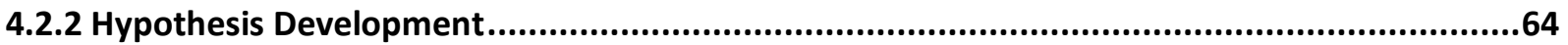

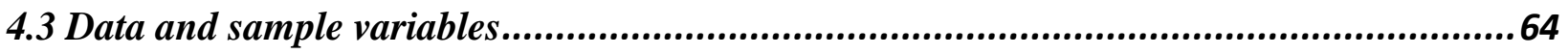

4.3.1. Sample Construction...........................................................................................................64

4.3.2. Data Description .................................................................................................................65

4.3.3. Graphical Representation of State average ESG issues and delisting activity for US firms ......67

4.4 Estimation strategy and methodology .......................................................................68

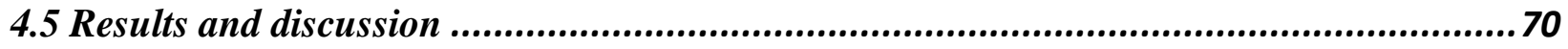

4.5.1. Analysis of the Hazard and Survival Curves (non-parametric approach).................................70

4.5.2. Estimation using a semi-parametric and parametric approach ................................................72

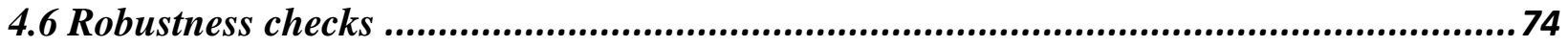

4.6.1. Controlling for Service - Manufacturing Industries and crisis periods....................................76

4.6.2. Other robustness checks ....................................................................................................

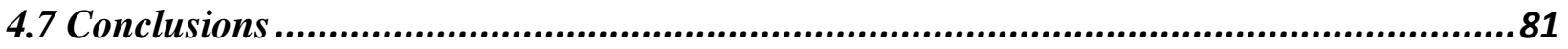

Chapter 5 - Conclusions and Research proposals .............................................................83

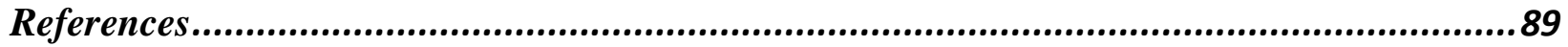

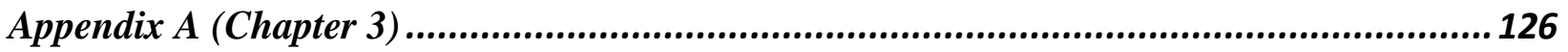

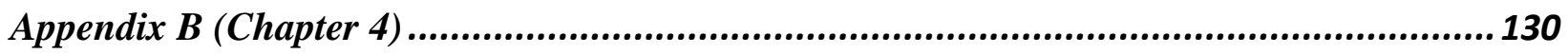




\section{List of Figures}

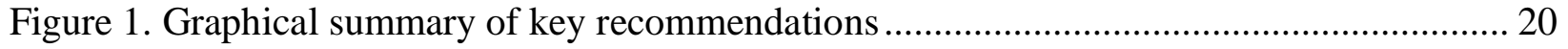

Figure 2. Drivers of ESG issues to shareholder value creation .............................................. 21

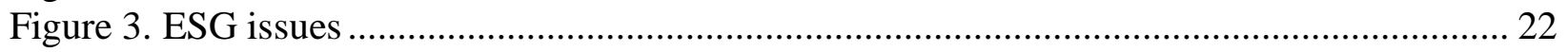

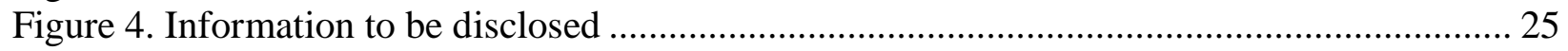

Figure 5. Creating a Virtuous Cycle: From Standards to Innovation ..................................... 28

Figure 6. Companies are pursuing sustainability in a way that creates value............................2 29

Figure 7. Evolution of $\$ 1$ invested in the stock market in value-weighted portfolios ................. 31

Figure 8. Spatial distribution of average sustainability performance for US firms, 2007-2016... 45

Figure 9. State average ESG issues for US firms over the period 2007 and 2016.................. 67

Figure 10. State average delisting activity for US firms over the period 2007 and 2016........... 68

Figure 11. Survival Estimates firms with and without ESG issues .................................... 71

Figure 12. Survival function firms with and without ESG issues.......................................... 71

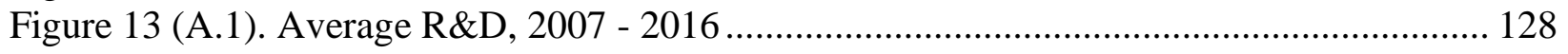

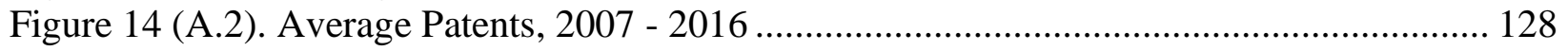

Figure 15 (A.3). Average Trademarks, 2007 - 2016............................................................ 129 


\section{List of Tables}

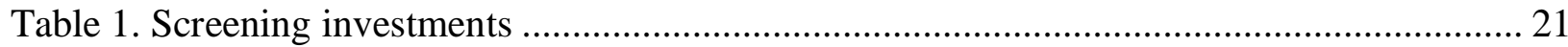

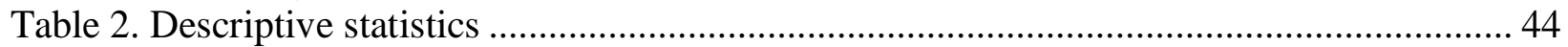

Table 3. Effect of Innovation on Sustainability (Dep. Var.: ESG) …………………….............. 47

Table 4. Effect of Innovation on the three major sustainability (ESG) components namely environmental (EP), social (SP) and governance (GP) ........................................................ 50

Table 5. Effect of the value of Innovation on Sustainability (Dep. Var.: ESG) ........................... 52

Table 6. Instrumental Variable Analysis on the Relationship Between Innovation and

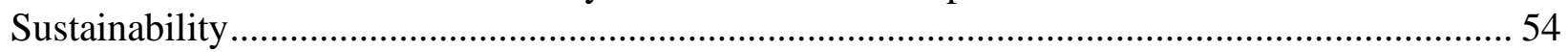

Table 7. Robustness results with Propensity Score Matching ..................................................... 56

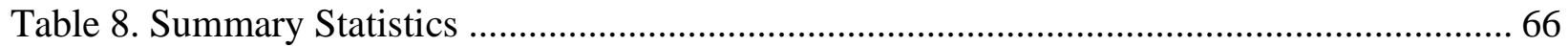

Table 9. Semi- parametric and parametric estimates of firms' ESG impact on the probability

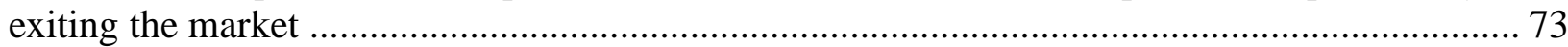

Table 10. Semi- parametric and parametric estimates of three major sustainability (ESG) components namely environmental (EP), social (SP) and governance (GP) impact on the probability exiting the market............................................................................................... 75

Table 11. Semi- parametric estimates of ESG impact on firm exiting the market Controlling for Service - Manufacturing Industries...................................................................................... 78

Table 12. Estimates of ESG impact on firm exiting the market Controlling for crisis periods .... 80

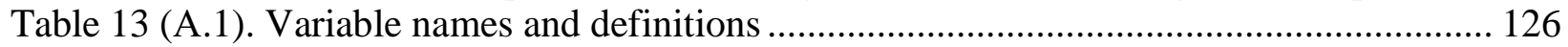

Table 14 (A.2). Estimates of equation (3)......................................................................... 127

Table 15 (B.1). Variable names and definitions. ............................................................... 130

Table 16 (B.2). Estimates of firms M\&A probability with respect to ESG issues and its three major components namely environmental (EP), social (SP) and governance (GP) on firms M\&A

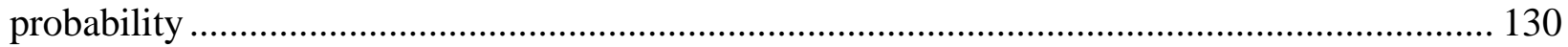




\section{Chapter 1 - Introduction}

\subsection{Research Background}

Sustainability is an essential business strategy for modern companies in order to achieve long term prosperity (Eccles and Serafeim, 2013). A company incorporates the sustainability principles (Environmental, Social and Governance - ESG) to its business strategy to expand the opportunities and to diminish the negative impact of its operation. Thus, a firm will create value for shareholders and stakeholders (consumers, investors, businesses and governments) as they stimulate this change with the expectation for the firm to behave responsibly (Schwartz and Carroll, 2003).

Sustainability is the ability to meet the needs of the present without compromising the ability of future generations to meet their own needs, having the ability to achieve profitable results during that time (WCED, 1987; Sneddon et al., 2006). So, sustainability gradually becomes a priority on the firm's strategy. A few years ago, Wang and Lin (2007) defined that sustainability is a collective effort to incorporate economic, environmental and social considerations into a firm's strategy. Historically, there are many theories related to business strategies. The research field has been enriched with a variety of proposals, such as the business life cycle model, fundamental business capabilities, strategic management and strategic leadership (Nelson and Winter, 1982; Barney, 1991; Hanks et al., 1993). Moreover, business strategy is a complex and dynamic process involving sequential behaviors and sustainability is an important process for the growth and longevity of a business. Constant changes in markets create new opportunities but, at the same time, require a revision of the old strategic methods and the invention of new ones that best meet the business objectives. Businesses are called upon to evolve based on innovation, market concentration, flexibility, extroversion, developed and sustainable societies. A firm's sustainability is based on structural changes that help it thrive in the business world. Consequently, it is important that every firm manages to attract new customers and retain existing ones at the same time, with the ultimate goal to increase market shares and sales (Bloom and Kotler, 1975; Buzzell et al., 1975). In

particular, corporate sustainability generates a competitive advantage (Du et al., 2011) as well as the ability to achieve solid economic growth in the future. 
Over the years, several scholars have tried to explain the essence of sustainability on business strategies by providing different terms. For example, Carrol (1991) argues that the term sustainability began to characterize many Corporate Social Responsibility (CSR) initiatives. Other scholars who further developed the concept of sustainability were Elkington (1998) who measured sustainability by encompassing a new framework called the Triple Bottom Line (TBL); and Starks (2009) who described Environmental, Social and Governance (ESG) criteria as a way to capture a firm's corporate responsibility practices. Laasch and Conaway (2015) conclude that investors, in order to have a Socially Responsible Investment (SRI), need to evaluate a firm's responsible management when selecting financial products, by using the firms' sustainability practices.

Nowadays, if a firm wishes to become sustainable, it should implement business strategies that focus on environmental, social and governance impacts, as ESG reporting is necessary for investors when they make investment decisions (Richardson, 2009). However, that was not always the case as most studies focused on environmental reporting (Guenther et al., 2007; Brammer and Pavelin, 2008) and on environmental and social reporting (Dawkins and Ngunjiri, 2008) but not on governance reporting (Cuesta and Valor, 2013). Cahan et al. (2015) demonstrate that a firm with ESG awareness faces higher evaluation and lower cost of capital and is more recognized and rewarded by the market. Consumers recognize the contribution to society and support firms with strong environmental and social reputation (Godfrey, 2005). They also considering above others the firm's carbon footprint and ethical strategy. So, there is a tremendous incentive to focus efforts on environmental and social responsibility in order to attract consumers, recruit and retain strong talent (Turban and Greening, 1996) and positively affect their external brand perception (Hammond and Slocum, 1996). These externalities are important to investors as they need to know all the information about a firm's strategy, through ESG sustainability reports (Eccles and Klimenko, 2019).

Surprisingly enough, the issue of sustainability is not a new one, as its roots can be traced back to the 1700s (Asongu, 2007). Corporate sustainability on the other hand, under its modern concept, emerged in the late 20th century (Purvis et al., 2019). In the 1960s and 1970s, firms couldn't realize their negative impact on the environment (Hart, 1997). In the early 1980s, the firms' need for sustainability was centered around business factors such as cost-saving, reputation, hiring the best people, risk management and resource efficiency. What is new, however, are the assumptions and 
the rationale of the business strategies used. In the last 30 years, companies have changed their focus shifting from a profit-centered perspective to a more elaborate one, thus integrating environmental, social and governance concerns. Nowadays, it is acknowledged that the traditional way of running an organization is not sufficient to meet the sustainability challenges the business world faces. This is due to many reasons, such as the competitive economic environment, population growth, pollution prevention, product stewardship, clean technology (Hart, 1997), the recognition of natural resources' limitation and the respect for human capital (Blower, 1997). Rosenberg (1981) and Porter (1990) state that a high concentration market could contribute more to innovation, productivity and sustainable growth prospects. All these reasons enhanced the awareness of consumers on environmental and social issues and forced firms to be more sustainable by transforming their business strategies. Despite all these reasons, until the end of 2010, innovation still was not a core factor of corporate sustainability. Nidumolu et al. (2009) define innovation as a necessary ingredient of sustainability that helps adaptive firms stand out. Also, Brown and Eisenhardt (1995), Wadhwa and Kotha (2006) and Miller et al. (2007), given the world economic depression in the last decade, conclude that innovation is an opportunity for firms to meet the new sustainability challenges.

As a result, firms change their business strategy and create new lines of business based on green mentality, as innovation drives sustainability (Porter and van der Linde,1995a; Nidumolu et al., 2009; Eccles and Serafeim, 2013). Galbreath (2013) provides evidence that innovation is the key to progress, especially during an economic crisis that raises concerns over companies' ethical, social, environmental and accountability performances. Thus, firms should innovate by exploiting their resources and competences. Innovation that creates sustainability is a business strategy that overcomes the traditional perception of designing green products and packaging. It implies improving the production process so that it can become more efficient, to reduce costs and waste in order to adapt to abrupt environmental changes (Schumpeter, 1942; Daft, 1982; Grossman and Helpman, 1994; Eisenhardt and Brown, 1998) and, by extension, increase profits. Furthermore, innovation compensates for the risk of resource price shocks and shortages. Independently, firms focus on sustainability in order to manage risks and improving their strategic position around natural-resource management. They increase their profits by creating loyalty, such as enhancing their brand name and market empowerment (Godfrey, 2005). 
So, sustainability is difficult to pin down since it encompasses so many different aspects. Due to the complexity of this subject, it's important to study its significance in a holistic way that approaches the issue rationally. In particular, there is an increasing interest in studies that integrate ESG data as firms' business strategies should incorporate transparency and accountability (Cuesta and Valor 2013). Also, ESG can quantify firms' corporate sustainability (Sandberg et al., 2009). The purpose of this thesis is to explore the importance of sustainability on modern firms' business strategies and, in particular, for firms operating in the US economy.

\subsection{Research Motivation and Contribution of the thesis}

The world's advanced economies are dealing with several deep-seated problems. Firms face advanced competition in our days. In the US in particular, the concentration of market power has been on the rise since the 1970s. The phenomenon of high market concentration allows for powerful firms to compete in a given market. According to IMAA (2017), the number of mergers completed annually rose from 2.308 to 15.361 , between 1985 and 2017. Baumol (1982) states that when markets are contestable and have fewer barriers to entry, then even firms in highly concentrated industries should be competitive. On the other hand, Gutierrez and Philippon (2017) argue that a highly concentrated industry prevents healthy competition. Dominant companies exercise market power and generate larger abnormal profits (Bain, 1951, 1956), therefore, competition is fierce and has created market entry barriers for new firms. As a result, the share of new firms in the US is declining.

None of this bodes well for the US economy. However, all of the above can be changeable in the pursuit of competitive advantage through innovation and sustainability. In the case of a high market concentration, there are a few and very large firms that pursue innovation that is protected by exclusive intellectual property rights (Acs and Audretsch, 1987). So, usually they invest large amounts in innovation to acquire a competitive advantage. Firms exploit opportunities in the market, develop new products or services and allocate resources within the business unit in order to acquire a competitive advantage (Utterback and Abernathy, 1975). The ultimate goal of each firm should be to gain a sustainable long-term competitive advantage over other businesses. 
Du et al. (2011) state that firms integrate sustainability into their business strategies in order to gain a competitive advantage, claim a larger market share, reduce asymmetry information and mitigate risk. The key to differentiating themselves over their competitors is innovation (Porter, 1985). Innovation allows firms to constantly renew or improve their products and adapt their production techniques to new developments. As a result, innovation becomes a self-sustained competition parameter, which increases sales and creates sustainability. Kleinknecht and Oostendorp (2002) argue that innovation leads to a competitive advantage, because firms compete with other market participants in terms of a technology (or quality) rather than price competition,

Moreover, firms incorporate sustainability into their business strategies as the demand for greater transparency and accountability is growing. Business leaders have already recognized that sustainability has to move from being voluntary to being mandatory. Sustainability has become a central issue for the United States Securities and Exchange Commission (SEC). In 2015, the SEC noted that the role of sustainability and public policy information in investors' voting and investment decisions may be evolving as some investors are increasingly engaging in certain ESG matters. Thus, the sustainability report can be important among investors, because it reveals information about ESG concerns and discloses information about responsible businesses that have the potential to bring significant benefits. Since April 13, 2016, several topics addressed the disclosure of company information related to sustainability and public policy issues, such as climate change, resource scarcity and good corporate citizenship, are often referred to generically as environmental, social, and governance (ESG) concerns. In the USA, the notion of a sustainability approach to business success has always been a voluntary one. However, a large number of firms in the USA, has already published annual sustainability reports, has fostered the idea that revealing this information, improves their abilities to attract and keep more and more stakeholders with them. Thus, firms have now realized that they need a business strategy based on sustainability throughout the supply chain.

In the past decade, there has been a tremendous incentive for firms to focus efforts on environmental and social responsibilities in order to attract consumers, recruit and retain strong talent, and positively affect their external brand perception. Due to this, corporate sustainability sets to become a vital factor to transform firms' strategy. Corporate sustainability is a company's 
delivery of long-term value in financial, environmental, social and ethical terms, through the implementation of a business strategy (Ashrafi et al., 2019). The quest for corporate sustainability is already starting to transform the competitive landscape, which will force companies to change the way they think about products, technologies, processes, business strategies and models. According to Haller et al. (2020), a survey by IBM and the National Retail Federation, 70\% of consumers in the US and Canada prefer to purchase products and services from a firm with a strong environmental and social reputation. Consumers are taking into account above others the firm's carbon footprint and ethical strategy. $69 \%$ of consumers are willing to pay a premium for recycled products and $80 \%$ of consumers want to know the origin of the products they buy. As it seems, consumers are choosing sustainable products, from sustainable companies, that are in alignment with their values (Whelan and Sacco, 2019). According to the Nielsen report (2018), "Brands that are able to strategically connect (sustainability) to actual behavior are in a good place to capitalize on increased consumer expectation and demand." As a result, the firms' sustainability information should reflect their business strategy.

Sustainability has intrigued economists from various fields (finance, environmental economics, industrial organization, managerial economics, among others) which along with the availability of data, helped spawn large empirical literature and also a number of important empirical contributions. The research of sustainability has received much attention over the last three decades and refers to many countries whereas it uses data at various level of aggregation, from individual Small and Medium Sized Enterprises (see Elke and Brouwers, 2010; Triguero et al., 2013; Morioka and Carvalho, 2016 for example) up to Multinational companies (MNCs) active to continent-size countries, like the US, or in economic blocks such as the EU and the OECD, covering periods of less than one year to longer than a decade. Methodologically, most of it employs standard parametric techniques.

The present thesis contributes to a newly growing literature on examining the main drivers of sustainability in a firm's strategy (Ziegler and Schröder, 2010; Horváthová, 2012; Triguero et al., 2013; Morioka and Carvalho, 2016). This strand of literature focuses on sustainability theory (Stubbs and Cocklin, 2008), corporate performance (Dyllick and Hockerts, 2002; Wagner, 2010; Searcy and Elkhawas, 2012), financial development (Brown et al., 2009; Horváthová, 2010; 
Endrikat et al., 2014), R\&D diffusion (Brown et al., 2009; Barbieri et al., 2010) and the link between innovation and sustainable development, among others (Elke and Brouwers, 2010; Barbieri et al., 2010; Kalkan et al., 2014).

One would expect that this volume of research would have led to some robust conclusions on the drivers of firms' sustainability along with other useful aspects (i.e. magnitude, duration, persistency, etc). A number of empirical studies have attempted to answer the fundamental question of how large is the impact of main drivers of sustainability on firms' strategy. However, this issue has drawn largely diverse answers. Part of the reason is that different firms exhibit different dynamics because they differ along relevant characteristics, including the magnitude of innovation, the level of profitability or the competitiveness pattern. Few researchers have addressed the question if innovation drives sustainability and if sustainability can create long prosperity. So, this dissertation contributes to the literature by providing sharp inference and guidance to policy makers (ministries, regulators, government authorities, etc) and market participants (managers, stakeholders, investors, etc) by exploring the importance of corporate sustainability on firms' strategy.

\subsection{Research Questions and Methodology employed}

There are several problems about what drives sustainability and how it is measured. Today, it is universally accepted that sustainability should be an integral part of the firms' life cycle. Investors use sustainability to capture the need for responsible management, considering environmental, social and governance criteria to build superior business strategies. This thesis aims to reveal a holistic framework of reference for conceptualizing what is sustainability and define the components that it consists of, by focusing on environmental, social and governance (ESG) factors. Although sustainability seems to be something new, the truth is that it can be traced back to the 1700s. As a result, we unfold the different meaning of sustainability and its evolution through time.

Moreover, we present the importance of innovation's impact on sustainability. In addition, we further investigate the effect of sustainability on firms' market longevity and its relation to firms' 
financial needs. Nevertheless, the tools used for the latter may and should be used in all firms, regardless of their strategy, since the ultimate goal of a firm is profit.

To summarize, this thesis tries to answer the following core research questions, dedicating a separate essay to each one of them:

1. Limitations of existing academic research on corporate sustainability as a business strategy (Chapter 2)

2. The influence of innovation on corporate sustainability in the USA (Chapter 3)

3. The impact of firms' sustainable performance on their market longevity in the USA (Chapter 4)

In order to attain our objectives, we employ a number of econometric methods which are further explained in Chapter 3 and Chapter 4. In Chapter 3, we use a linear regression model. We estimate our model with industry and year fixed effects. Although we use a rich set of control variables we may still have unobserved variables that are missing from our model as well as problems that may arise from the heterogeneity. In order to address these issues for robustness, we use propensity matching score and 2SLS technics. In Chapter 4, in order to investigate the association between sustainability and firms' survivability in the market, we use the semi parametric and parametric survival model. The first one (semi parametric) is the Cox proportional-hazards (Cox, 1972) and the second one (parametric) links firms' survival time to covariates by using Weibull distribution.

\subsection{Structure of the thesis}

The present thesis is organized into five chapters to present the research in a systematic way and meet the core research questions. Chapter 2 discusses the evolution of sustainability in the business world in a critical manner and the importance of public awareness in its early configuration. In particular, it presents the definition of Socially Responsible Investment (SRI) and explains how investors assess companies according to their sustainability practices. Scholars use different terms to describe sustainability such as Corporate Social Responsibility (CSR), Triple Bottom Line 
(TBL) and Environmental Social Governance (ESG) criteria. In general, Chapter 2 is a review of the literature of ESG's integration to business strategies. ESG can be measured, valued and quantified. We describe the pillars of sustainability (ESG) to introduce the importance of their integration to business strategy.

Chapter 3 explores the impact of innovation on corporate sustainability (ESG), as it is considered a controversial topic among economists and scholars. Following the review of existing literature, it becomes apparent that there is a knowledge gap, in spite of the significant contributions in the field. The reason for this is that existing studies fail to incorporate the different aspects of innovation to corporate sustainability. In order to investigate the relation between innovation and corporate sustainability we use input factors in the corporate innovation process (such as $R \& D$ investments) and output factors (such as patents and trademarks, organization types, and knowledge capital). To reach our objective, we create a firm specific dataset of 1.048 US firms, over the period 2007-2016 and by using various panel data econometric techniques, we analyse in depth and quantified innovation (patents, trademarks, R\&D) possible spill over effects on ESG and finally on firms' strategy. The results show that a firm's corporate sustainability is enhanced by its innovative activity and its exposure to relatively higher than lower innovation environments. Also, the quantity and value of innovation definitely enhance corporate sustainable performance.

Chapter 4 investigates the corporate sustainable performance to achieve a firm's' longevity on the market. This issue is particularly important, especially to investors. Sustainability reports are a tool that help them make their investment decisions. To reach our objective, we construct a firm specific dataset of 1.585 US firms, over the period of 2007 to 2016 and by using various panel data econometric techniques, we analyse the impact of ESG on firms' probability to exit the market, which is a direct test of the role of sustainability, as a long term risk mitigation tool. The results document that firms with higher sustainable performance are more likely to remain listed to markets, for longer periods and, therefore, benefiting their investors.

Chapter 5 presents the thesis' conclusions and summarizes the key findings about business strategies, sustainability and innovation. In particular, it reveals the conclusions of each research 
question and their contribution to the business industry. Moreover, it offers further recommendations for future research.

\subsection{Conclusion}

This chapter has presented the purpose, direction and overview of the present thesis. The research background and framework of reference were discussed to identify existing research on corporate sustainability. Also, it included the research motivation and contribution of the thesis. Finally, the thesis's research questions and methodology were established. 


\section{Chapter 2 - A critical review of the literature on corporate sustainability as a business strategy}

\subsection{Introduction}

This chapter is a critical discussion of the literature on sustainability's evolution as a business strategy. In particular, it examines the concept of Socially Responsible Investment (SRI) as a practice that involves the evaluation of Environmental, Social and Governance (ESG) criteria so that investors can make a responsible investment decision.

A new kind of investment has emerged in the last decades called Responsible, Ethical or Sustainable investment (Socially Responsible Investment - SRI). This investment takes into account social factors, besides financial ones, as an effort to better manage risk-returns (Sandberg et al., 2009). This trend has undergone a dynamic development in the investment market, caused by people's awakening regarding the environmental movement. Toxic waste, pollution, water, air, plants, people and animals are all connected as one universe and there is awareness about the consequences of the irrational use of the natural resources in our ecosystem (Carson, 1962). Using the term SRI, we mean investment in tangibles or intangibles that focuses on long-term value respecting environmental, social and ethical criteria (Renneboog et al., 2008). It can thus be conceivably hypothesized that as the mentality and lifestyle of consumers change, they tend to incorporate their principles into their investments' objectives. Social responsibility is an element of sustainability while Socially Responsible Investment is the practical use of social responsibility. Traditional SRI reflects a set of values, derived from religion and has to exclude immoral practices. Modern SRI reflects a set of personal values, that assimilate social, environmental and governance extensions (ESG) (Renneboog et al. 2008; de Colle and York, 2009).

Initially, investment decisions were focalized on liquidity, risk, and return. Currently, sustainability has gained the attention of investors, as a factor with strong impact on the choice of a fund (Cengiz et al., 2010). SRI is a kind of financial intermediation tool that helps investors evaluate funds and their components in terms of sustainable performance. It is worth noting that investors use ESG to form business strategies that increase their investment efficiency following their morals, so SRI could be considered as an appropriate response to the moral crisis of the modern era. ESG can be 
segmented and used to measure the sustainable performance that a fund has concerning SRI. In fact, the SRI portfolio management integrates Environmental, Social and Corporate Governance (ESG) criteria into every asset assessment and selection operation (Sandberg et al., 2009). Consequently, it is a tool that creates reliability for investors as they can evaluate a company's environmental impact (water and waste management, natural scarcity, greenhouse gas emissions, pollution, deforestation, etc.); a company's impact on stakeholders in terms of human rights (workplace diversity, impact on local communities, health and safety, employee relations); a company's corporate governance (labour practices, executive compensation, political contributions, bribery, corruption, board independence, composition, tax strategy, etc.). As a result, a company provides all the necessary information about its transparent and accountable activity (Weber, 2014). Hence, the ESG is set to become a vital factor as it is referred to as sustainability by the industry. The SRI and the ESG analysis facilitate the selection of a betterquality investment that leads into optimum financial returns. This is a great tool in order to evaluate, assess and minimize the risks caused by environmental, social and governance considerations.

\subsection{Socially Responsible Investment (SRI)}

This chapter discusses the definition of Socially responsible investment (SRI). Also, it examines the levels of heterogeneity, the strategies and the criticism around SRI. In particular, it explores the historical evolution of the concept of SRI from the 1700s until the modern era. The most important fact is that SRI is still the most important tool to evaluate an investment decision.

Socially responsible investment (SRI) is based on non-financial factors such as ethical, social and environmental factors (Judd, 1990; Miller, 1991; Ward 1991; Harrington, 1992; Domini, 2001; Camejo, 2002; Sparkes, 2002; Schueth, 2003; Sparkes and Cowton, 2004; Sandberg et al., 2009) and risk - averse stocks of businesses with no respect to society and regulations that seek to avoid negative externalities (Renneboog et al., 2008). SRI considers both social and financial goals, as it also focuses on capital allocation, asset allocation and security selection by integrating moral and ESG concerns during the investment process. So, investors follow a SRI strategy when they focus on the value of specific investments (Umlas, 2008). SRI has four levels of heterogeneity; the terminological, the definitional, the strategic and the practical level (Sandberg et al., 2009). Mercer (2007) states that SRI is an investment which has as a priority to achieve social and environmental 
goals along with financial objectives. However, some scholars use alternative terms about these types of investment, such as ethical investing (Simon et al., 1972; Domini and Kinder, 1986; Sparkes, 1995; Lang, 1996), social investment (Powers, 1971; Bruyn, 1987; Kinder et al., 1993; Lowry, 1993), responsible investment (Sullivan and Mackenzie, 2006), natural investment (Brill et al., 1999) and values-based investing (Fehrenbacher, 2001). This appears to be the result of the existence of different definitions of SRI in different countries. According to the OECD (2007) definition of SRI, some countries have focused more on others factors apart from the social and environmental criteria. The UK and US Social Investment Forums (SIFs) include community investments and some economically- targeted investments (ETI). The UK SFI incorporates ethical considerations into the definition of SRI, while the Canadian and US SFIs do not. Also, the UK SFI emphasizes the equal importance of the social, environmental and financial aspects, while the US SFI is more values driven. Australia, includes personal values, Sweden includes ecological and ethical matters while Asia focuses more on social justice, peace, healthy environment and financial considerations. So, a SRI focuses on many topics such as ethics, social, governance, human and labor rights, diversity, environmental stewardship, consumer protection, norms, community, financial issues and so many aspects that can be considered social responsibility. SRI is often described in academic literature as a superior investment that takes into account financial, ethical (Brill and Reder, 1993), social and environmental criteria (Cowton, 1994). Furthermore, it integrates ethical concerns into an investment (Domini, 2001). As a result, the definition of SRI takes into account the integration of financial variables compared to non-financial ones. Thus, the the content of SRI is established by managers and their constituents (Goy and Schwarzer, 2013).

The criticism around the SRI, is that investors do not have access to its components. Although there are many definitions of SRI, none focuses on financial concerns (Sparkes, 2001). As a result, SRI is often characterized as deficient because investors find it difficult to define the factors that determine it and the particular aspects that improve an investment so that it can become a SRI (Monks, 2002). The question is how non-financial concerns can influence the investment process, as they seem to carry a higher degree of risk than traditional investments. SRI incorporates a considerable amount of strategies. There is the avoidance strategy (Cowton, 1998) or negative screening (Kinder and Domini, 1997), where investors avoid investing in companies that are immoral or incorporate negative ethical criteria in their decisions; the supportive strategy (Cowton, 
1998) or positive screening (Kinder and Domini, 1997), where investors are attractive to companies that are moral or incorporate positive ethical criteria in their decisions; the shareholder activism strategy (Guay et al., 2004), where investors choose companies that are immoral but they use their right to introduce and vote on resolutions in order to redirect them to moral criteria; the strategy of community investing (Guay et al. 2004), where investors support minority communities or those with low economic development. But what kind of strategy can be defined as socially responsible? Sparkes $(2001,2002)$ focuses on profitability versus self-sacrifice. Cowton (1998) and Powers (1971) focus on effectiveness versus purity, namely investors should choose a SRI in order to avoid immoral investments. So, SRI helps investors support companies whose practices and strategies reflect their personal values (Pasewark and Riley, 2010). As a result, investors balance their desire to gain profit with their moral ethics and the pressure from corporations to turn their irresponsible practices into sustainable ones. This practical level of SRI heterogeneity, arises from the need to develop venture strategies into investment criteria. The differences on a practical level of a SRI, are caused by differences in the cultural, ideological, religion, political and legal system and investors' preferences that differ across countries (Cooper and Schlegelmich, 1993; Sandberg et al., 2009).

Over the past decades, SRI has attracted a lot of attention. Increased awareness in social and environmental issues has changed the business understanding for sustainable approaches (Pienitz and Vincent, 2000). According to Hoepner et al. (2016), a sustainable investment takes place when a firm conducts business with ethical consideration without compromising the needs of future generations. As a result, sustainability is attracting considerable interest due to its importance in a firm's strategy as a tool for making ethical investments. Investors use SRI in order to evaluate the sustainability and ethical influence of an investment within a company.

The increased need for social responsibility in recent years has been developing dramatically. Modern SRI is an investment that integrates social, environmental and governance extensions (ESG) (United Nations Principles for Responsible Investment, 2006; Sandberg et al., 2009; European Social Investment Forum, 2014). Socially Responsible Investment is closely related to the notion of Corporate Social Responsibility (CSR) (Goy and Schwarzer, 2013). Thus, modern SRI focuses on industries that promote environmental, social and governance practices and avoid 
immoral industries such as tobacco, liquor, alcohol, gambling, weapons manufacturers and distributors (Sandberg et al., 2009). This investment technique (positive and negative screening) is the frontier where traditional SRI becomes modern. Moreover, industries that are heavily reliant on natural resources and fossil fuel are becoming less attractive with this new investment decision making criteria. Another factor behind the growth of SRI, is ethical consumerism (Schueth, 2003), where consumers prefer to purchase products and services, even if they have to pay a premium (Hillman and Keim, 2001; Hart and Dowell, 2011), from a firm with a strong environmental and social reputation (Yadav, Han and Rho, 2016). Over the last years, some severe catastrophes have contributed to increasing focus on responsible investing and the identification of good corporate, environmental and social practices amongst other areas. Collapsing factories (Dhaka), vehicle emission scandals (Volkswagen), nuclear disasters (Chernobyl, Fukushima), human rights exploitation (Hennes \& Mauritz), economical frauds (Rabobank) and oil spills (Exxon Valdez, British Petroleum) have all been proven harmful to the environment, society and any investor who ended up exposed to having stock during the affected period. Therefore, criteria like transparency, governance and sustainability have become very significant (Renneboog et al., 2008).

SRI relates to an actual investment strategy, where investors' focus is on socially responsible companies. Fund managers have shown increased interest in investing in firms with social impact, over the years (Eurosif, 2006). The United Nations Principles for Responsible Investment (UNPRPI) collaborated with the UN Environment Programme Finance Initiative and the UN Global Compact in 2006. This partnership led to the encouragement of investors to integrate environmental, social and governance (ESG) criteria in their investment portfolio as an additional tool to overcome possible risks that arise from the modern business environment of competitive markets. Moreover, UNPRPI considers all the ESG factors to be of equal weight, but the governance vector attracts most of the attention in the investment world, as many investors consider the outcomes of governance issues more valuable than those of environmental and social issues (Sandberg et al., 2009). 


\subsubsection{History of Socially Responsible Investment}

The initiator of the first SRI as an investment combining profit with social values was related to religious orders such as Christianity, Judaism and Islam, on the subject of how to use money (Renneboog et al., 2008). The origins of SRI may date back to 1758 to the Religious Society of Friends (Quakers), where they prohibited members from participating in the slave trade (Asongu, 2007). The first reference of SRI was recorded in North America (Domini, 2001). Over time, SRI has attracted investors in many countries. Traditional SRI reflects a set of values originating from religion and the concept to not harm others (Sparkes, 2003). So, its concept was based on avoiding products or industries that are in conflict with a set of moral values (negative screening). The First World War was the trigger for investments in morals funds, as the government stopped supporting companies engaged in unfair labor practices (Martin, 1986). Moreover, traditional SRI was heavily influenced during the period 1960-1970, as it was the era when American investors questioned which values were more important, such as the anti-war movement, the maturity of movements on racial equality, women's rights, the protection of the consumer and the environment, played an important role (Schueth, 2003). As a result, social and cultural influences combined with faithbased values were the foundation for the development of SRI in North America. Saul Alinsky and Ralph Nader, US activists, were the pioneers, along with the church, that adopted practices of shareholder activism to force firms to engage in more social and environmental matters (Vogel, 1978).

In 1969, an international network of firms with ethical values called "Friends of the Earth International" was founded in San Francisco as concerns over nuclear energy were raised. Apartheid, climate change, civil rights, gender wage gap, use of nuclear power and the Vietnam war were some of the catalysts for the creation of the SRI industry. Even if some portfolios could profit from the war effort, socially responsible investors began searching for ways to avoid war profiteering in their portfolios. In 1971, the Pax Fund, the first American independent ethical investment fund, was launched to provide an option to religious investors looking to avoid direct investments in the supply chains of Agent Orange, a toxic weapon that was designed to defoliate forests and terrorize populations during the Vietnam War. The level of public awareness had risen. As a result, the racist system of apartheid in South Africa aroused a lot of concerns about SRI. 
Many investors pulled off capital from companies that were active in South Africa and this led to economic instability and the collapse of apartheid (Sparkes, 2002). In addition, in 1971, the First Spectrum Fund was launched with the condition that no investment would be made without taking into consideration firms' environmental performance, civil rights and consumer protection. In 1972, the Dreyfus Third Century Fund was launched, with a mission to discover firms that reveal evidence about their conduct on business, in comparison with other companies with respect to industry, contributing in this way to the improvement of quality of life in America (Moskowitz, 1973). The following years, a number of legislations followed, including the Environmental Protection Agency and the Clean Air Act in 1970, the Clean Water Act in 1972 and the Endangered Species Act in 1973.

In 1980, traditional SRI in North America focused on broad market portfolios that did not include investments in nuclear energy, gambling, weapons, tobacco, pornography and alcohol. Thus, everyone avoided investing in companies with egregious patterns of behavior regarding workplace, governance, environment, social justice or other issues that could be quantified or identified (Sparkes, 2002). In 1990, the Domini Social Index was created, as a consequence of the increased number of SRI mutual funds and the need for a tool to measure a firm's performance in an alternative, more sustainable way. It was the first capitalization weighted index mutual fund that was based on the traditional SRI framework, creating a critical track record significantly contributing to the growth of the SRI industry. The Index included companies with a wide range of ethical, social and environmental criteria and provided information on their screened investments performance versus their unscreened counterparts (Louche, 2004). Another important factor that reinforced the SRI concept were the Dow Jones Sustainability Group Indexes. One way to make a business commit itself to following SRI was corporate engagement and shareholder activism, which is a critical part of traditional SRI. The pursuit of the powerful notion of leveraging ownership in a company, through voting and management control, was a tool to improve firms' behavior in the long run. Many firms publish their integration regarding those indexes, in order to highlight their social and environmental contribution to community (Renneboog et al., 2008).

SRI appeared in the late 1960s in the United Kingdom (UK), when a number of groups were exploring opportunities for this type of investment. Charles Jacob, a member of the Methodist 
Church, established the first British ethical investment fund in 1973. A few years later permission was granted, but the fund was repeatedly denied approval by the Department of Trade, mainly because of doubts that investors would show interest. In 1983, Ethical Investment Research Services (EIRIS) was established as the UK's first independent research service for ethical investors. It was designed to exclude firms that operated in areas that the Methodist church and the Society of Friends (Quakers) did not approve. In 1984, the Stewardship Unit Trust, the Stewardship Life Fund and the Stewardship Individual Pension Fund were launched, emphasizing environmental and sustainability principles (Lulewicz and Kilon, 2014). In 1988, the Merlin Ecology Fund was launched focusing on a green fund investment approach. In 2000, a law was enacted and imposed occupational pension schemes, aiming to enhance investor decisions around social, environmental or ethical matters (Louche and Lydenberg, 2006). One of the reasons for this was the increased SRI's attention by investors. Until the launch of this law, pension funds, were unwilling to include SRI investments in their portfolios, questioning the low yields and the effectiveness of this investment process (Sandberg et al., 2009). Hence, the interest of investors was increasing, causing the launch of the FTSE4Good index in July 2001 (Friedman and Miles, 2001). On the contrary, Cox et al. (2004) document that regulatory actions did not contribute significantly to the importance of SRI in pension funds.

Over the years, SRI funds were emerging in many countries; in Sweden, the first SRI fund (Ansvar Aktiefond Sverige) was founded in 1965 by the Church of Sweden; in Finland, the church created two ethical funds; in France, the first SRI fund (Nouvelle Strategies Fund) was founded in 1983 by the Catholic Church Nicole Reille (Czerwonka, 2011). Furthermore, in Canada the first SRI fund was founded in 1986 by the Vancity Credit Union; in the Netherlands, the first SRI fund (Het Andere Beleggingsfond) was founded in 1990 by ABF, a combined initiative of Church groups and the environmental movement. In Germany, local churches created some ethical funds (KD Fonds Ökoinvest) in 1991. In France, in Italy, in Belgium, in Norway in Austria and in Spain the SRI funds appeared in the mid 1990s (Eurosif, 2003). 


\subsection{Environmental, Social and Governance (ESG)}

This chapter discusses the definition of Environmental, Social and Governance (ESG) criteria. Also, it fully analyzes the concept of ESG and its three vectors and how its integration to business strategies can contribute to shareholder value creation. A significant reference is made to sustainability reports and their impact on investors' investments.

The Environmental, Social and Governance (ESG) concept was conceived in 2005, in a landmark study entitled "Who Cares Wins", arising from the imperative need to create a conditionality for analysis, in terms of sustainability. The same year, the United Nations Environment Programme Finance Initiative and the UN Global Compact established the Principles for Responsible Investment Initiative (PRI). But, Starks (2009) made the most important contribution to the definition of ESG, as she was the first to describe this new acronym as a way to capture firms' corporate social responsibility activities. Hence, a framework was created as a tool to create stronger and more resilient financial markets; to increase awareness and mutual understanding of the involved stakeholders on ESG issues, to contribute to sustainable development through responsible management practices and to improve trust in financial institutions (Figure 1). This new framework on ESG was created for one additional reason: the need to address modern society problems, such as climate change and firms' corruption that were damaging the markets. As a result, the complexity of the markets and their dependence on the intentions of stakeholders (Aras and Crowther, 2009) led to demand for transparency and accountability. So, the evolving view that corporate governance factors can influence the markets gave a huge push as to the credibility of ESG. 
Figure 1. Graphical summary of key recommendations

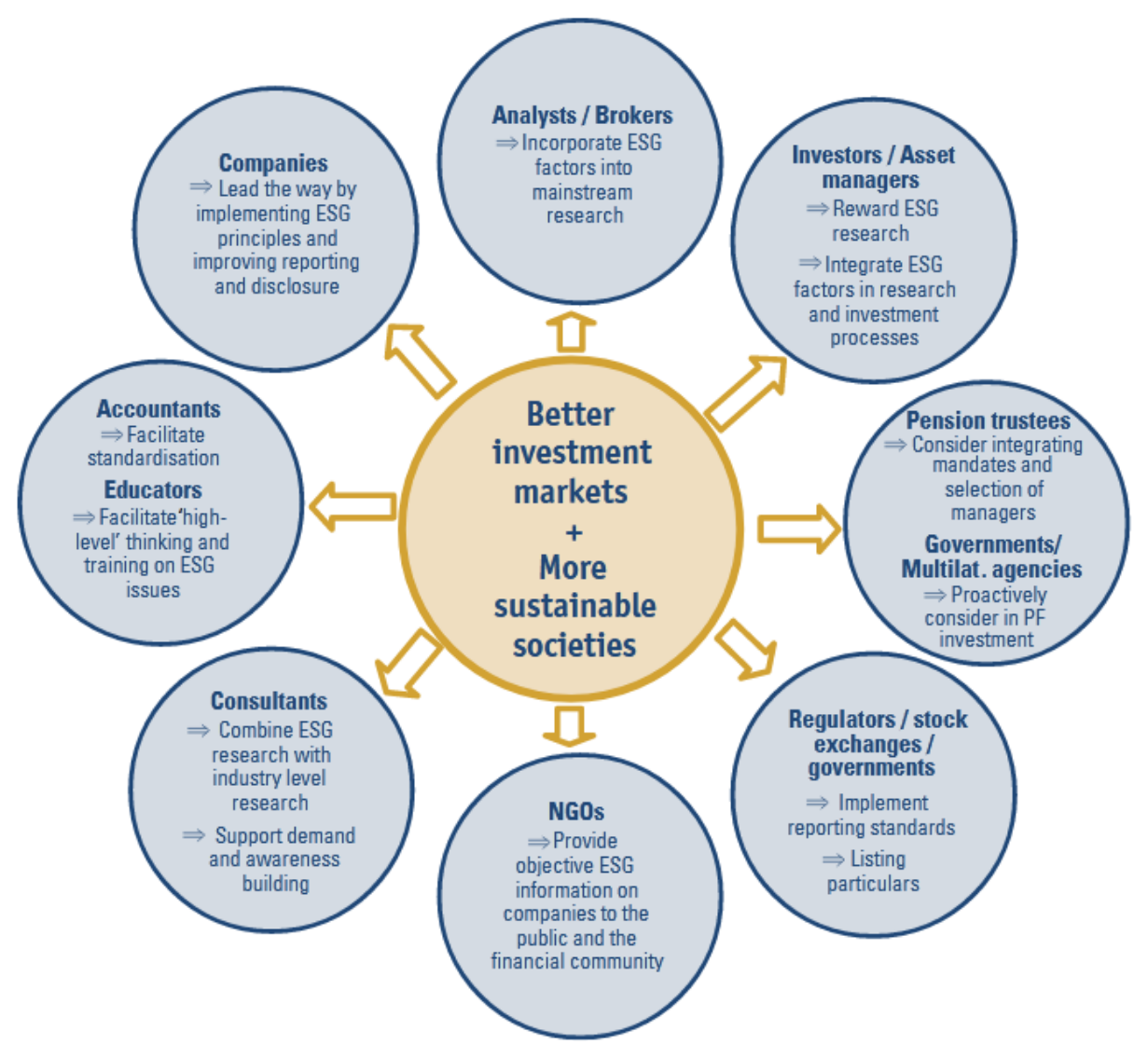

Source: Who Cares Wins, 2004

Investors make a Socially Responsible Investment (SRI) by analyzing companies according to their ESG disclosures, in order to adopt responsible management (Sandberg et al., 2009). Institutional investors consider it essential to quantify and integrate corporate governance factors into their decision-making investment (Eccles and Klimenko, 2019). Investors use ESG in order to maximize their portfolio profits (Ioannou and Serafeim, 2019) (Figure 2). 
Figure 2. Drivers of ESG issues to shareholder value creation

\section{Drivers of ESG issues to shareholder value creation}

- Early identification of emerging risks, threats, management failures

- New business opportunities

- Customer satisfaction and loyalty

- Reputation as an attractive employer

- Alliances and partnerships with business partners and stake-holders

- Enhanced reputation and brands

- Reduced regulatory intervention

- Cost savings

- Access to capital, lower cost of capital

- Better risk management, lower risk levels

Source: Who Cares Wins, 2004

In addition, ESG has a positive impact on a number of factors such as transparency, accountability, responsible management, shareholder value, portfolios performance and investment returns. From all the above it is clear why investors use ESG as a tool for positive or negative screening (Ioannou and Serafeim, 2019) (Table 1).

Table 1. Screening investments

\begin{tabular}{|l|l|}
\hline $\begin{array}{l}\text { Passive } \\
\text { screening }\end{array}$ & $\begin{array}{l}\text { Passive screening involves making investment decisions by following indices with ESG } \\
\text { benchmarks, such as the Dow Jones Sustainability Index, the Dow Jones Islamic Market } \\
\text { Index, FTSE4 Good and KLD's Domini 400 Social Index. }\end{array}$ \\
\hline $\begin{array}{l}\text { Positive } \\
\text { screening }\end{array}$ & $\begin{array}{l}\text { Positive screening sets inclusive criteria that must be met before an investment is included } \\
\text { within a portfolio, such as strong employee relations, good corporate governance, } \\
\text { consistent product safety, an excellent charity donation record or superior environmental } \\
\text { performance. There are a number of different forms of positive screening, including best- } \\
\text { in-class (selecting the companies that are best' in their industry regarding ESG } \\
\text { considerations) and thematic investment (selecting companies that have made a } \\
\text { commitment to responsible products or services, such as investing in renewable energy } \\
\text { technologies). }\end{array}$ \\
\hline $\begin{array}{l}\text { Negative } \\
\text { screening }\end{array}$ & $\begin{array}{l}\text { Negative screening applies criteria to exclude companies on the basis of ESG performance. } \\
\text { alcohol, weapons, tobacco, GM foods or nuclear energy; are engaged in gaming or animal } \\
\text { testing; have poor labour standards; or are guilty of breaching human rights. }\end{array}$ \\
\hline
\end{tabular}

Source: UNEP Finance Initiative, 2005

According to the United Nations Principles for Responsible Investment, ESG refers to three different though related fields within 'social awareness'. ESG vectors have strong financial 
relevance. The ESG indicator of a firm encompasses the environmental vector, including climate change, GHG emissions, global pollution, impacts on landscapes, ecosystems and biodiversity, overuse and wasting of resources, waste issues, animal mistreatment; the social vector, which is divided into two parts; the community relations that include human rights abuses, corporate complicity, impacts on communities, local participation issues and social discrimination; and the employee relations that include forced labor, child labor, freedom of association and collective bargaining, discrimination in employment, occupational health and safety issues, poor employment conditions; the governance vector, including corruption, bribery, extortion, money laundering, executive compensation issues, misleading communication, fraud, tax evasion, tax optimization and anti-competitive practices to ensure transparency and accountability (Figure 3).

Figure 2. ESG issues
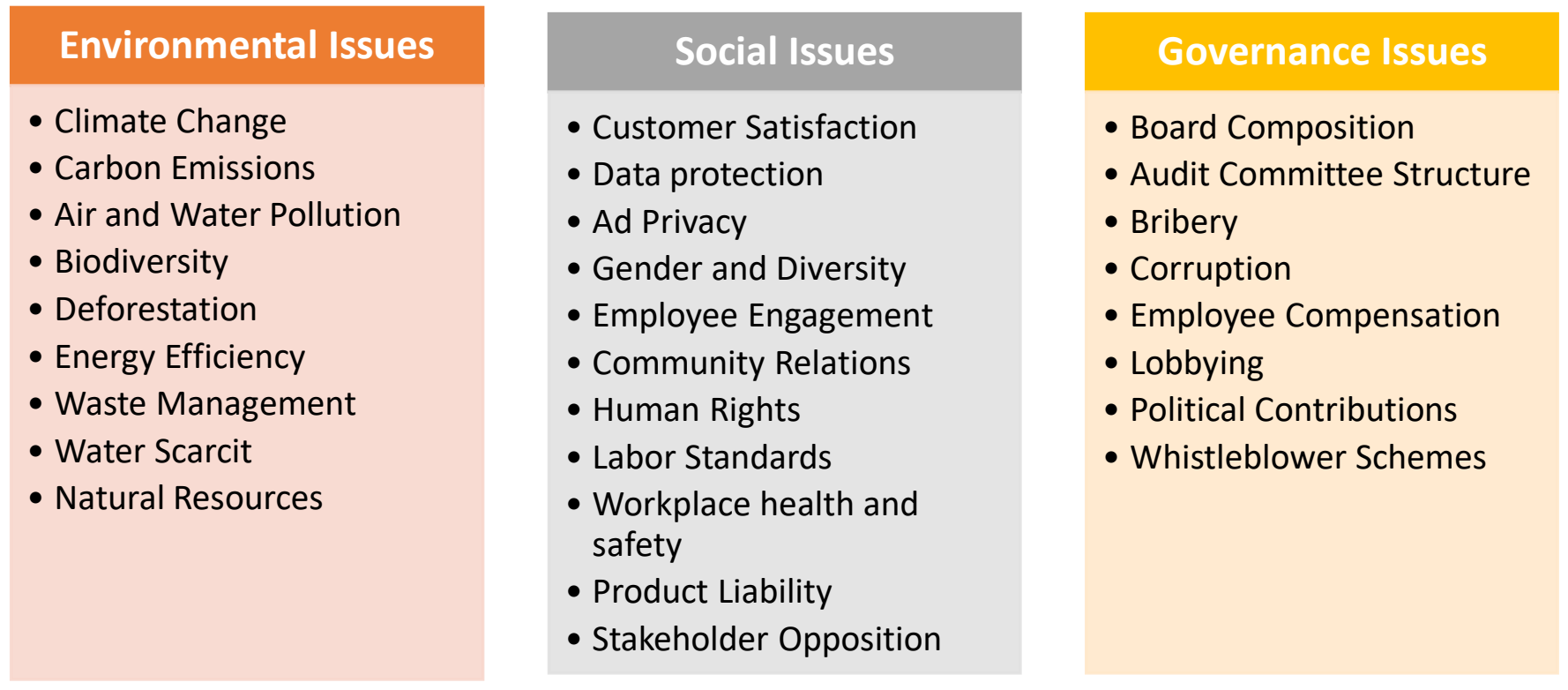

Source: Who Cares Wins, 2004

Eccles et al. (2014) found that companies with more sustainable business traits outperform their peers over the long term. However, ESG does not include the economic vector. The economic performance of the firm has received less attention, despite the fact that environmental, social and governance (ESG) dimensions are critical elements of the CSR concept (Sacconi, 2006). Investors are concerned with the relationship between firms' ESG factors and financial performance. They adapt ESG in their business strategy, because it captures the three main dimensions of corporate 
sustainability holistically. Moreover, ESG generates positive impact on corporate performance (Waddock and Graves, 1997; Van Beurden and Gössling, 2008) through reducing operating costs and risks, creating consumer confidence and enhancing efficiency and competitiveness (Barney, 1991; Porter, 1991; Hart, 1995).

ESG disclosure provides information on firms' sustainable strategy and emphasizes their contribution to society. It is also a good measure that incorporates information on business transparency and accountability (Weber, 2014), due to its potential long-term impact on the community where a firm is active. Sustainability (ESG) documents essentially ratings, that help investors evaluate companies based on a comparative assessment of their quality and performance on environmental, social or governance issues (SustainAbility 2018, p. 4). Sustainability rating agencies focus on firms' environmental social and governance issues (Avetisyan and Hockerts 2017). Companies with higher ESG performance are more likely to disclose information compared to those with a lower one (Verrecchia, 1983; Dye, 1985; Cheynel, 2013). Today, many stock exchanges have ESG indexes such as Dow Jones Sustainability, FTSE, MSCI, NASDAQ, OMX, NYSE, World Index, Ethical Index Euro, Ftse4Good, UNGC 100, Vigeo, ECPI, STOXX, D\&I and the S\&P (Searcy and Elkhawas, 2012). Firms' ESG performance incorporates information for possible future risks and is a crucial tool for stakeholders in order to perform financial analysis and make investments in particularly responsible companies. This implies that stakeholders can take superior firm-level decisions on stock performance and fixed-income investment by analyzing sustainability performance (Derwall et al.,2005; Edmans, 2011). According to Cuesta and Valor (2004), ESG disclosures should meet criteria about relevance (or materiality), comparability, reliability and accessibility in order to provide quality information. The assurance of ESG disclosures through a company's performance will decrease the credibility gap, as it is the main factor highlighting quality. The form and intensity of ESG reporting differ across companies (Ioannou and Serafeim, 2019). Assurance and consistency in ESG disclosures is linked to the requisite of comparability in the industry (Dando and Swift, 2003). Contrariwise, companies' environmental and social policies cannot entirely eliminate the credibility gap (Manetti and Becatti, 2009). 
Today, a large number of firms publish ESG reports voluntarily, as the pressure for corporate accountability is increasing (Waddock, 2004; Beurden and Gössling, 2008; Junior, Best and Cotter, 2014) and in order to extend their legitimacy among stakeholders (Nilolaeva and Bicho, 2011; Reverte, 2009). In addition, ESG disclosures may differ across countries (Gray et al., 1995) and they are not homogeneous across cultures (Campbell et al., 2003). In the USA, although ESG reports are voluntary, firms tend to publish annual sustainability reports, fostering the idea that by revealing this information they will improve their abilities to attract stakeholders. Companies that disclose ESG information create a strong brand name, enhance their reputation (Hammond and Slocum, 1996) and can access more capital than their competitors (Bhattacharya and Luo 2006; Cheng et al., 2014). Moreover, as a result of transparency and accountability, firms decrease the risk, reduce the asymmetric information and face less equity and capital cost (Francis et al., 2004; Botosan, 2006; Armitage and Marston, 2007; Ghoul et al., 2011; Reverte, 2012).

In Europe, the 2014/95/EU directive came into force in the financial year that began on 1 January 2017. This directive obligates large companies (listed companies, banks, insurance companies and other companies designated by national authorities as public-interest entities - exceeding 500 employees) within the EU to report on their policies about environmental, social, anti-corruption and bribery issues. They also report information about the diversity on company boards as well as the risks they pose to their economic environment, including:

i. "a brief description of the undertaking's business model;

ii. a description of the policies pursued by the undertaking in relation to those matters, including due diligence processes implemented;

iii. the outcome of those policies;

iv. the principal risks related to those matters linked to the undertaking's operations including, where relevant and proportionate, its business relationships, products or services which are likely to cause adverse impacts in those areas, and how the undertaking manages those risks;

v. non-financial key performance indicators related to the particular business" (Official Journal of the European Union, 2014)

The information to be disclosed, as explained in Figure 4, is broken down by topic, scope, and type. 
Figure 3. Information to be disclosed

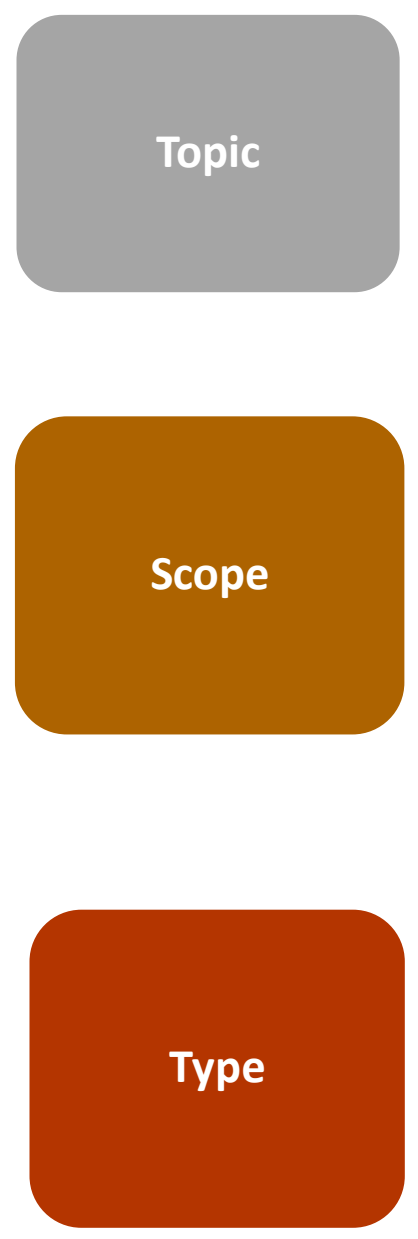

- Environmental matters

- Social matters

- Employee matters

- Respect for human rights

- Anti-corruption and bribery matters

- Business model (management and organization)

- Policies pursued by the company, outcomes and non-financial performance indicators

- Principal risks linked to the companies' operations, products and services, supply chain andsubcontractors, where relevant

- Use of energy and water resources

- Greenhouse gas and pollutant emissions

- Potential impact of risks on environment and health and safety

- Social aspects of employee management and policies to ensure gender parity, implementation of international conventions and dialogue between management and employees

- Respect for human rights and policies to prevent violations and avoid discriminatory attitudes

- Anti-corruption policy, both active and passive, indicating the tools adopted

Source: Venturelli et al., 2017

Each company has the discretion to choose which indicators and standards will be revealed in their annual reports. However, they are obligated to include their policies, risks and results related to ESG. As a result, this directive will impact many foreign firms doing business in the EU and will force nonfinancial disclosures to be made available to the stakeholders. Consequently, a sustainability report can be a useful tool to attract stakeholders, since companies' disclosure information about ESG concerns, reduce asymmetric information about responsible management and business strategies in the context of sustainable development. Moreover, investors use ESG data to influence firms' responsible behavior (van Duuren et al., 2016; Amel-Zadeh and Serafeim 
2018). According to Donaldson and Preston (1995), the stakeholder theory discloses information that can be descriptive; to uncover the mechanisms that companies use to choose ESG indicators, instrumental; to make profit, normative; to create positive impact and managerial; to reveal organizational structures and policies.

Through ESG, investors are motivated to invest responsibly in order to create value (Margolis et al., 2009; Ghoul et al., 2011). ESG is a proxy based on the mentality of the market and society. Global warming, inequalities, safe working conditions and corruption are important issues for stakeholders. The great challenge of firms, is the adjustment between the maximization of profits and the adaptation to become responsible. Investors with ethical awareness follow innovative strategies based on ESG factors (Eurosif, 2014). Trinks and Scholtens (2017) document that ESG integration is progressively part of fiduciary duty and simultaneously reserving investments personal values' reflection and preferences in order to make profit. As a result, investors can identify responsible companies by using ESG data and consumers can be informed about the production process of final goods and services. Eccles and Klimenko (2019) report that policy makers form regulations taking into account ESG performance in their effort to ensure firms' ethics and the stability of modern capital markets.

Moreover, investors consider their potential investment options for long term returns through sustainability reports. Investors' expectation force firms to use more resources on producing mandatory ESG reports, as they recognize and use ESG information to understand their corporate purpose, operational strength, efficiency, risk management and responsible strategy (Bailey et al., 2000). Ioannou and Serafeim (2019) argue that the economic effect of the ESG regulations appears to be positive for companies, even if overcoming mandatory regulations is often costly. Institutional investors are hesitant to include ESG in their investments as their responsibilities limit in optimization of shareholder values without taking into account obligation on issues like social, environmental and governance criteria. In contrast to that, Clementino and Perkins (2020), state that ESG ratings are just the necessary data for investors to conclude their decision-making by providing important information on non-financial issues. But that creates great dangers. One danger could be to underestimate ESG ethical application on business management or on the decisionmaking process (Moon, 2002; Fleischman et al., 2019). Another danger could be the company's 
obsession to reach specific standards (ESG ratings) in order to show better market performance than its competitors without considering all the ethical dimensions of its actions (Caulkin, 2002; Ims et al., 2014; Moore and Gino 2015). Friedman (1970) states that a company's only social responsibility is to maximize its profits, since its ethical awareness can create costs and decreasing corporate returns. Previous work has proved that ESG has an effect on financial performance. Some authors argue that the long-term responsible strategy has positive outcomes for shareholders (McGuire et al., 1988; Barnett and Salomon, 2006), while others claim that a company should focus on short term responsible strategy in order to have positive effects (Wang et al., 2008). In fact, Shaukat et al., (2016) suggest that there is a causal relation between ESG and financial performance. However, there is still a need for further research as it's not clear whether ESG has a positive or negative effect on financial performance (Van Beurden and Gössling, 2008; Galbreath, 2013)

Nevertheless, ESG ensures that although it may be a costly business strategy (Palmer et al., 1995) that includes risks for financial performance (Baumol 1991), it enhances the competitive advantage. This result is significant as the integration of sustainability in the company's strategy can create the right framework for competitors in the long run (Eccles et al., 2014; Eccles and Klimenko, 2019). Sustainability increases growth opportunities and minimizes risk exposure. Furthermore, ESG is used as a deterrent tool for costly fines. For example, a company's actions that could cause negative impact on the environment, bribery of the Board of directors or human rights abuse or weak labor standards may result in costly fines. A company may integrate ESG in its business strategy to reduce its footprint. Furthermore, a company that invests in energy efficiency can differentiate itself and gain credibility. Thus, strategic investments on environmentally friendly processes, social awareness actions (human rights, labor standards, workplace health and safety etc) (Francis and Armstrong, 2003) and responsible management will reduce the long-term costs and create a competitive advantage through innovation (Brown and Eisenhardt, 1995; Wadhwa and Kotha, 2006; Miller et al.,2007). In addition to the above, a company's strategy can be regarded as management quality through ESG, as it can face long-term external factors, creating a competitive advantage (Ling et al., 2007). So, Melnyk et al., (2003) strongly suggest that every company's strategy must be ethical and responsible in order to ensure longevity. Du Rietz (2018) claims that there is a strong connection between information, 
knowledge, accountability and transparency in companies' ESG strategies. Through access on ESG reports, investors can modify their decisions in order to integrate sustainable strategies. This will create a cycle that will reveal new opportunities and create value. This cycle (Figure 5) depends on the quality of ESG data. As a result, the market becomes more transparent and accountable by following a benchmarking behavior (Park and Ravenel, 2013).

Figure 4. Creating a Virtuous Cycle: From Standards to Innovation

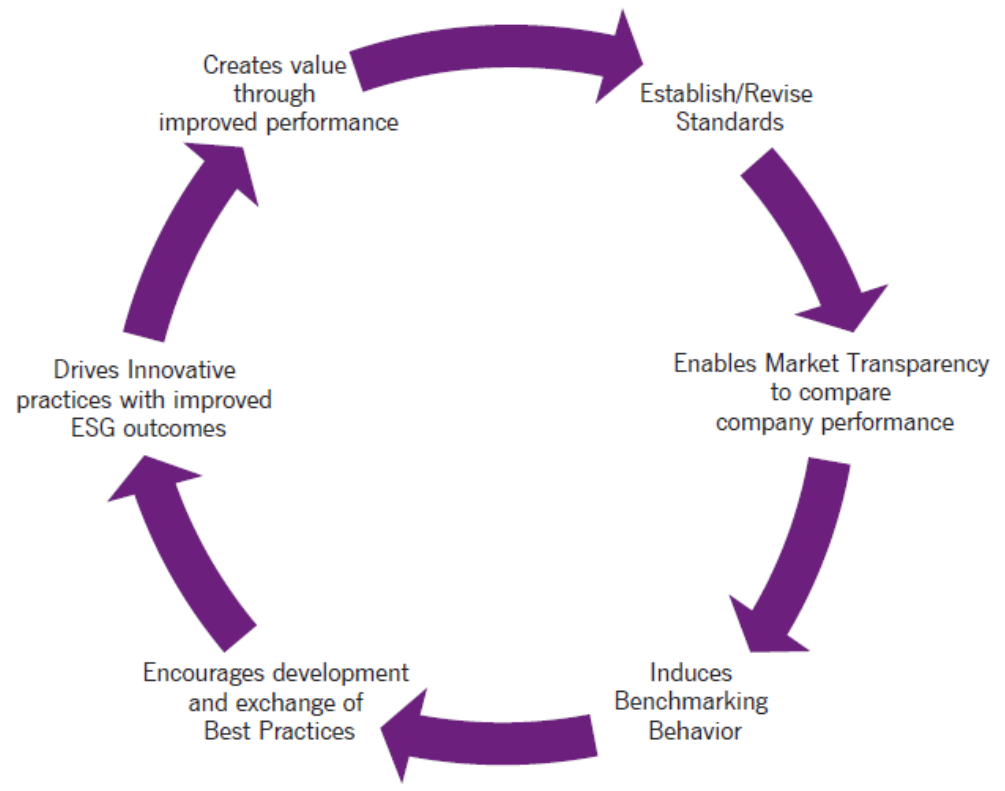

Source: Park and Ravenel, 2013

For many investors ESG is a risk mitigation tool that helps form risk aversion strategies and increase long-term sustainable financial returns (Collin, 2009). It is believed, that firms that avoid risks but grab opportunities, will be more sustainable in the long run. The responsibility to consider the interests of all stakeholders (Freeman, 1984) and the push for global reporting standards (transparency and accountability) at large firms is critical for the success of ESG, as it has helped investors be more informed. Firms that incorporate sustainability (ESG) into their business strategy tend to be more productive and create value for third parts (stakeholders, investors, employees, customers) (Harrison and Wicks, 2013).

Chitra Sriyani and Kumudini (2017) state that integrating ESG criteria into a business strategy is critical, since possible dissatisfaction of the stakeholders will have a negative impact on a firm's financial performance (Clarkson, 1995). Furthermore, ESG reports help investors identify long- 
term risk factors and investment opportunities. In this way, the ESG scoring framework is more likely to mainstream investing because it is compatible with quantitative driven investing. Eccles and Viviers (2011) report that ESG may have a quantitative influence on the financial structure of a company. The methodology for the ESG quantitative analysis mirrors the value of an intangible asset, such as the different types of social capital in their financial rating. Thus, human-related factors are embedded in social criteria. This contrasts with SRI, which has a more qualitative nature. This ESG's compatibility has helped fuel its growth and managers have been using sustainability to make better investment decisions because what is measured can be improved (Figure 6).

Figure 5. Companies are pursuing sustainability in a way that creates value

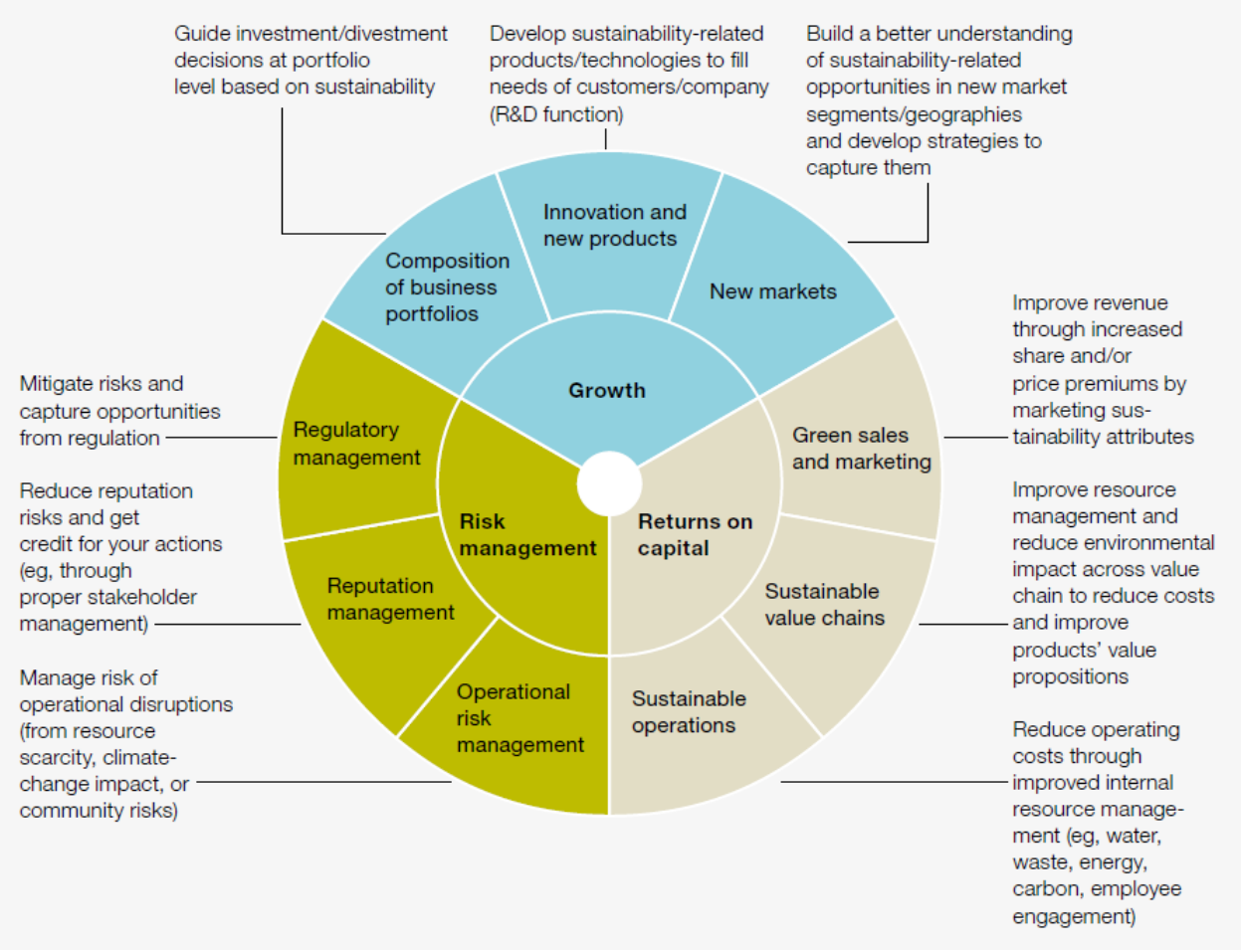

Source: Bonini and Görner, 2011 


\subsection{Why integrate ESG into a business strategy}

This chapter presents a critical assessment of why investors should choose firms' ESG practices in order to make an SRI. In particular, it summarizes all the important reasons which have been historically involved in relation to ESG's integration into business strategies.

Socially Responsible Investment is based on investors' analysis for the responsible management of a company. Responsible management has three basic domains, Responsibility, Sustainability and Ethics (Laasch, and Conaway, 2015). Therefore, investors use Socially Responsible Investment to analyze companies according to their ethical behavior. SRI integrate Corporate Social Responsibility (CSR), Triple Bottom Line (TBL) and Environmental, Social and Governance (ESG) criteria. CSR presents the behavior of a company to its stakeholders (Carrol, 1991). TBL creates the company's sustainability strategy (Elkington,1998). ESG quantifies a company's sustainability performance (Sandberg et al., 2009). The ultimate goal of each company is to maximize its profits. The increased interest around ESG has many reasons. We suggest that ESG is the main factor for a company to increase its market share, stakeholders' preference in an ethical way by overcoming regulations and maximizing profits (impact investing). This happens either because firms choose to be responsible or under the pressure of certain regulations (Van Marrewijk, 2003).

Firstly, each company needs to increase its market performance. The more ethical a company, the better its market performance (Figure 7). Investors prefer to invest their money in ethical companies, as they can attract more consumers through their ethical behavior. Consumers choose companies that provide access to their ESG performance. Firms that disclose information on their ESG performance are more accountable than others and offer a more transparent business activity. Companies' sustainability, based on indexes, can affect the shareholder structure (Kaiser, 2019). As a result, firms seek long-term shareholders, such as value-driven investors or profit-seeking investors (Derwall, Koedijk, and Horst, 2011) looking for relatively high short-term sustainability innovation costs vis-a-vis long-term benefits (Whelan and Fink, 2016). 
Figure 6. Evolution of $\$ 1$ invested in the stock market in value-weighted portfolios

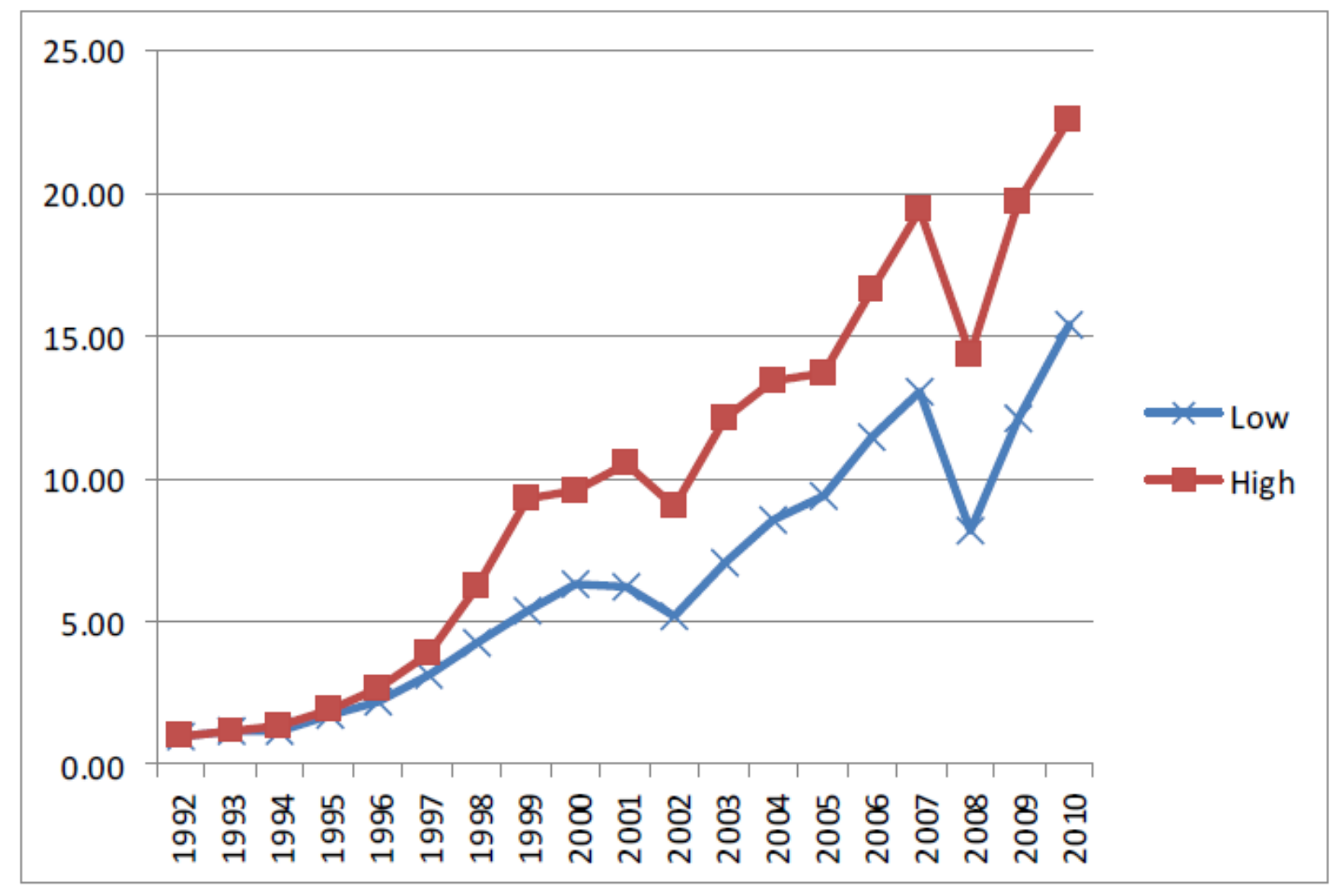

Source: Eccles, Ioannou and Serafeim, 2014

Secondly, companies that integrate ESG into their sustainability performance are greener and more ethical. So, they adopt green business strategies to avoid fines and overcome regulations. Companies' environmental compliance can be measured by fines. As a result, these fines can have a strong impact on firms' performance and profits (Bhat, 1998). So, as companies integrate sustainable strategies, they can reduce the possibility to be penalized. In this way, companies can generate value for their stakeholders and create a sustainable society. Francis and Armstrong (2003) suggest that a good ethical image, through sustainability, can boost companies' reputation and help them overcome regulatory challenges and decrease the possibilities for penalties. As a result, companies will have higher returns and access to capital and to other resources needed (Rindova and Fombrun, 1991), as the consumers favored them instead of companies that do not show environmental and social awareness. Companies that don't integrate ESG criteria experience bad performance as they don't have access to private equity and have a high cost of capital (Crifo and Forget, 2013). 
Thirdly, companies should incorporate sustainability (ESG) into their business strategy. In this way, they become more competitive, reduce risk and create value for all their stakeholders. Creating profit to benefit only the shareholders, will cause short term economic growth. On the contrary, according to the stakeholding theory, the company is a collective business activity that is engaged in creating value for all the stakeholders (Beurden and Gossling, 2008; Freeman et al., 2010). As long as a firm is concerned about its impact on society and the environment (globally and locally), the more it will be accepted in the mind of consumers. ESG can be considered as a business strategy against reputation risks (Godfrey et al., 2009) that creates positive economic value (McWilliams and Siegel, 2001) and enhances the stakeholders' commitments (Godfrey 2005; Wang et al., 2008). Moreover, the ESG strategy can enhance a company's reputation as an attractive employer (Turban and Greening, 1996) creating a positive outcome on corporate financial performance (Edams, 2011). As a result, we suggest that a company should follow transparency practices and be accountable for each strategic decision, so as to create long term economic prosperity.

Consequently, we conclude that companies that integrate sustainable strategies are more prone to acquire longevity. We provide evidence that ESG is an integral part of a company's strategy, in order to to attract more investors and create value for all stakeholders. Nowadays, investors support companies with environmental and social awareness and better corporate governance for long term returns.

\subsection{Conclusion}

This chapter has presented the literature on the evolution of sustainability as a business strategy. In particular, the concepts of Socially Responsible Investment (SRI) and Environmental, Social and Governance (ESG) criteria were examined. More specifically, we studied the historical evolution of SRI. Finally, a critical assessment of why investors should examine a firm's ESG practice when making a SRI was presented. 


\section{Chapter 3 - Corporate sustainability performance and Innovation: A firm-level analysis for the US}

This chapter focuses on the relationship between innovation and corporate sustainability, as it constitutes a long-lasting debate among policymakers and researchers. Also, it aims to use a unique micro-level panel dataset consisting of a large number of firms scattered across the US states over the period 2007-2016. It identifies that the quantity and value of innovation enhance the sustainability level, whereas these effects are strengthened in times of recession (global financial crisis). Lastly, policy implications relating to the nature of corporate sustainability performance are also provided.

\subsection{Introduction}

The study of corporate sustainability is rather new in the field of economics and management science. Existing literature deals with the environmental, social and governance (ESG) dimensions of companies, as these are important factors for the economic value, competitiveness, and resilience of the company in the modern globalized environment. The researchers argue that companies, by incorporating sustainable policies into their strategy, enhance transparency by reducing asymmetric information, thus increasing trust between different stakeholders (Eccles et al., 2014). Companies with a strong environmental and social reputation, contribute more to social well-being than others (McWilliams and Siegel, 2001; Godfrey, 2005; Jacobs et al., 2010; and Hsu, 2012).

Wang and Lin (2007) address the topic of corporate sustainability in terms of the collective effort needed to incorporate economic, environmental, and social considerations into a business strategy. Other articles consider further aspects of corporate sustainability like the rise of business cost resulting from companies' non-compliance with governmental rules and regulations that meet sustainability goals. Since the non-compliance cost is usually burdensome for both small and large companies, it is argued that companies which implement sustainable policies not only outweigh the cost of regulations but also build positive customer relationships (Sen and Bhattacharya, 2001), enhance their brand name, and establish reputation (Fombrun and Shanley, 1990). 
The increasing importance of sustainable practices is further reflected in a series of studies covering a wider range of concerns. To give some typical examples, Ziegler and Schröder (2010) explore the impact of sustainability on the firm's size. Other studies (Margolis and Walsh, 2003; Wagner, 2010) examine possible interactions between sustainability and corporate performance whereas a number of researchers investigate the impact of sustainability on financial performance (Eccles et al., 2014; Dimson et al., 2015; Fatemi et al., 2015, Edmans, 2011; and Krüger, 2015).

Nowadays, it is evident that the corporate dimension of sustainability is a complex issue, as it involves various aspects of management, including cost savings, reputation maintenance, hiring talented people, risk management performance and achieving resource efficiency. All types of companies and businesses of all sizes have now recognized that achieving sustainability through innovation plays a catalytic role in their development. Yet, despite the growing concern about the impact of innovation on corporate sustainability, we fairly think that the subject remains an open challenge for researchers and policy makers who demand to better understand it. Part of the reason for these unmet expectations is that different businesses have different dynamics depending on their unique characteristics, such as the degree of innovation implemented, the level of market recognition and the way they compete. The argument that different aspects of innovation create a unique and superior business combination, goes back to Schumpeter (1942). Recent research has shown that innovation can be expressed through various knowledge assets such as $R \& D$ investments and patents (Cockburn and Griliches, 1988; Hall et al., 2005). Further, Allegrezza and Guarda-Rauchs (1999) see trademarks as a soft intensive form of product innovation that adds value to a company. This idea that companies use trademarks to strengthen their strategic position has also been extensively explored by scholars such as Sandner and Block (2011), Block et al. (2014) and Bernstein (2015).

This chapter follows closely the steps of various seminal studies in the field (Corrado and Hulten, 2010; Eisfeldt and Papanikolaou, 2013, 2014; and Peters and Taylor, 2016). Our purpose is to investigate whether firms that are engaged in innovation investments become more sustainable. In doing so, we develop four testable hypotheses regarding the impact of various aspects of innovation on sustainability (ESG). 
This research contributes to the literature on many fronts. First, we use a newly developed dataset to measure the Socially Responsible Investment (SRI). ${ }^{1}$ In contrast to CSR perspective which has a self-regulation form and provides information about company's efforts to have a positive impact on employees, consumers, environment, community, and Triple Bottom Line approach, which focuses on future strategies, ESG quantifies company's sustainability performance to arrive at a more precise assessment of a company's actions. By using ESG, our research takes advantage of this new sophisticated metric that can quantify in detail a firm's sustainable performance and examines the sustainability -innovation nexus in a more comprehensive way. Second, previous literature has focused only on the research and development (R\&D) (Brown et al., 2009) measure of innovation input and relates this measure to sub-quantitative corporate sustainability measures (Wagner, 2010). Instead, we examine the impact of research and development expenses (innovation inputs), patents, trademarks, organizational and knowledge capital (innovation outputs) on the viability of a firm. To our knowledge, this is the first research to perform such a comprehensive analysis.

The rest of this chapter proceeds as follows. Section 2 refers to the existing theory and presents a testable hypothesis for our empirical part. Section 3 describes the data, discusses the sample selection, and reports the descriptive statistics evidence. Section 4 introduces our estimation strategy whereas Section 5 presents the analytical framework and discusses the main results. Section 6 discusses the robustness analysis. Section 7 concludes the chapter.

\subsection{Related literature and Hypotheses Development}

\subsubsection{Environmental, social, and governance framework}

The model of the ESG aspects of corporate sustainability was first introduced back in the 1950s (Carrol, 2009) and since then has gained significant attention within the business strategy analytical

\footnotetext{
${ }^{1}$ SRI includes any strategy which seeks to achieve both financial return and social/environmental goals. Under SRI, firms are encouraged to reduce environmental degradation by promoting consumer protection, human rights, and racial or gender diversity. Corporate social responsibility (CSR) integrates the economic, legal, ethical, and philanthropic responsibilities of a company towards its stakeholders (Carrol, 1991; Hill et al., 2007), the Triple Bottom Line (TBL) approach (Elkington, 1998) that considers the economic, environmental, and social dimensions into a firm's strategy and (ESG) index quantifies company's exposure to environmental, social and governance matters.
} 
framework. ${ }^{2}$ Within the last years, many researchers cast light on various issues related with this framework of reference. In particular, Ghoul et al. (2011) report that a strategy based on the ESG model, creates firms' value. $\mathrm{Ng}$ and Rezaee (2015) propose that firms that achieve a simultaneous social, environmental, and financial performance increase their corporate sustainability and, in this way, create value for all stakeholders (Schuler et al., 2017). In other words, when a firm embraces a strategy in the context of the ESG model and conducts business with ethical consideration (Hoepner et al., 2016), it incorporates the organizational capital that matters for the stakeholders and succeeds in becoming economically effective (Sharfman and Fernando, 2008; Schuler et al., 2017).

Firms that implement strategies concerning social responsibility to protect the surrounding community have also many advantages. According to many scholars, firms invest more and more in green practices, therefore managing to reduce their carbon emissions (Hart and Ahuja, 1996). As a side effect, environmentally-friendly firms accomplishing higher returns than others which disregard society's welfare (King and Lenox, 2002). Eccles and Serafeim (2013) argue that the firms, through these types of strategies, can contribute to social prosperity and create a more sustainable society. Others, such as Stern (2008) claim that firms adopt green strategies only to overcome regulations and avoid legal penalties imposed by disobedience to the law such as carbon tax. Whatever their intentions, companies benefit from the introduction of these socially responsible behavioral motivations and, thus, often succeed in producing profitable results. Furthermore, firms with strong environmental awareness, have lower loan spreads and lower average capital cost (Sharfman and Fernando, 2008; Ambec and Lanoie, 2008).

McGuire et al. (1988) demonstrate that a firm can be exposed to risks from lawsuits and fines, as an aftermath of an absence of a strategy related to social responsibility. Furthermore, if a firm fails to commit to the community, consumers may boycott its brand (Sen et al., 2001). Margolis and

\footnotetext{
${ }^{2}$ The ESG describes the environmental, social and corporate governance issues. The environmental vector, includes climate change, GHG emissions, global pollution, waste issues, and animal mistreatment. The social vector is divided into two parts; the community relations that include human rights abuses, corporate complicity, impacts on communities and social discrimination and the employee relations that include forced labor, discrimination in employment, poor employment conditions. The governance vector that includes corruption, bribery, extortion, money laundering, executive compensation issues, misleading communication, fraud, tax evasion, tax optimization and anticompetitive practices to ensure transparency and accountability.
} 
Walsh (2003) showed that as firms become more socially responsible and concentrate on environmental, social and ethical cases, they establish a strong brand name and outperform their competitors. Employees' relations (Edmans, 2011) and social giving (Brammer and Millington, 2008) can be further identified as corporate social dimensions, that a firm should address to improve its reputation and social image (Fombrun and Shanley, 1990; Hsu, 2012). Consumers prefer to buy a product or a service from firms with ethical awareness (Godfrey, 2005). Consequently, firms incorporate strategies sensitized in socially sustainable practices to reinforce customer loyalty (McWilliams and Siegel, 2001; Sen and Bhattacharya, 2001). Corporate governance can be quantified and its consequences may have positive effects on the profits of a firm (Godfrey, 2009). A firm's ultimate social responsibility goal is to increase profits. Shareholders observe that the financial performance is better as the corporate governance increases and invest in firms with higher ESG performance (Cremers and Ferrell, 2014; Jo and Harjoto, 2011), which in turn leads to lower cost of equity financing (Cremers and Nair, 2005).

It is worth noting that according to several surveys, institutional ownership (shareholder governance mechanism) and the percentage of external directors on corporate boards have a negative effect on bond yields and a positive effect on bond valuations. Creditors consider that the firms with ESG concerns may damage their reputation and financial position while lenders consider the firms with ESG strategy as a profitable investment that can lead to better lending conditions, through transparency and accountability.

\subsubsection{The multi-dimensional nature of innovation}

Innovation is the way to companies' s growth and evolution. Porter and van der Linde (1995a) report that firms in the modern competitive economies innovate with the purpose to raise productivity, to lower the total cost and improve their value. Nidumolu et al. (2009) consider innovation as the key to progress whereas other scholars (Brown and Eisenhardt, 1995; Maskus and Penubarti, 1995; Wadhwa and Kotha, 2006; Miller et al, 2007) claim that firms anticipate competitors more on a technology and quality basis rather than price competition. Hall (1992) argues that firms with innovation and intangible assets create a competitive advantage and value for a longer period of time. 
To understand the conceptual differences of innovation as well as their relationship to corporate sustainability, we need to study further the different aspects of innovation such as R\&D, patents, trademarks, organization capital and knowledge capital. R\&D activities, patents and trademarks were often used as individual variables for measuring companies' innovation activities (Kleinknecht et al., 2002). Using a set of key variables that construct the concept of corporate innovation, this research is the first of its kind which studies the overall impact of innovation across all dimensions of firms' sustainability.

In particular, we distinguish between the input and output factors of the innovation process. Due to their differences in many ways, especially considering the high uncertainty surrounding investments in R\&D, their effects on firms' sustainability may differ. Firstly, we use as an input factor to the innovation process, the knowledge capital, which is valued as the replacement cost of unsuccessful expenditures on R\&D (Sandner and Block, 2011; Peters and Taylor, 2016). Knowledge-based capital consists of all the knowledge that a company possess, such as information, experience, learning skills of its employees and it's a key factor for efficiency and innovation. Chen, (2008) and Boiral (2002) report that the knowledge capital of a firm is part of the intangible capital that is created by $R \& D$ and gives a significant competitive advantage to a firm.

Secondly, we take a step forward and separate the output factors of the innovation process to record the difference between an innovation with a patent and a non-patented one. We use a number of innovation-outputs, such as patents, trademarks, organizational and knowledge capital, to explore their impact on corporate sustainability.

Organizational capital is another important corporate asset that contains diversified risk characteristics for a firm's internal and external environment. There are many scholars in the field that studied organizational capital and have analyzed its important contribution in the production processes and systems (Prescott and Visscher, 1980; Atkeson and Kehoe, 2005; Eisfeldt and Papanikolaou, 2013; Lustig et al, 2011). Organizational capital can include knowledge that has been registered, captured, exchanged or even codified, through several tools, such as databases, manuals, routines, and patents. It constitutes of human and social capital interactions. It is a value 
contributing asset that differentiates the firm from its competitors and, thus, it creates a competitive advantage. Moreover, it enables tangible and intangible assets, such as machinery, buildings, land, patents, brands and human capital, to be productive. To capture the aggregate effect of innovation on corporate sustainability, we use the intangible capital construct which is the sum of the knowledge capital and the organizational capital (Peters and Taylor, 2016). As far as we know there is no previous research that studies in such detail the impact of innovation aspects on sustainability so we expect to make a significant contribution.

\subsubsection{Sustainability: A risk mitigation tool}

Being innovative and sustainable requires more than just having good ideas. By investing in R\&D, companies generate new knowledge and increase their knowledge capital. But companies need to keep in mind that innovation activity is a long and continuous process, idiosyncratic and without guaranteed results (Holmstrom, 1989). To gain competitive advantage through innovation (Brown and Eisenhardt, 1995; Wadhwa and Kotha, 2006; Miller et al, 2007), firms have to take risks and invest significantly in intangible capital (Helfat, 1994). They should use trademarks (Cockburn and Griliches, 1988; Cardozo et al., 1993;) and patents (Hall et al., 2005; Sandner and Block, 2011) to promote and secure new products. The implementation of such strategies increases investment in intangible assets and the uncertainty of the company. Eisfeldt and Papanikolaou (2013) report that firms with higher organization capital are considered riskier by shareholders than those with physical capital. This leads shareholders who invest in those companies to seek higher risk premiums. Huberman and Regev (2001) report that intangible assets due to the increased asymmetric information they enclose are difficult to be assessed, especially by investors with limited attention. From all of the above, we end up that firms with increased intangible assets such as R\&D, patents, trademarks, knowledge, and organizational capital involve significant nonsystemic risk and are hard to be evaluated. However, during the years firms tend to hold more and more intangible assets (Syverson 2011; Kogan et al., 2017) to become more competitive and increase their performance (Grant, 1996). Hence, there is a strong need to implement risk control and limitation policies through monitoring and the development of appropriate innovation strategies. 
The development of a framework with appropriate sustainability strategies and the disclosure of information about this implementation can help investors to evaluate long-term risk factors and identify investment opportunities based on these risks. Innovation is a long-term investment so investors and shareholders want to minimize the risk to invest in firms that are likely to be out of business shortly. Sustainability scoring framework is a tool that enables investors to formulate strategies in this direction by making quantitative driven investing. One of the many advantages of this quantitative analysis is that mirrors the value of the firm's intangible capital (Peters and Taylor, 2016). Investors, through the implementation of the ESG analytical framework, are motivated to invest responsibly in order to create value (McGuire et al., 1998). The ESG is a risk mitigation tool that can reduce asymmetric information around innovation and create transparency. It consists of an important tool especially for the risk averted investors who shape strategies with the belief that the benefits may lie more in reducing risk versus adding value. Following the discussion above, we came to the conclusion that is very useful for highly intensive innovation companies to be sustainable.

\subsubsection{Innovation and sustainability nexus}

Given that the concept of sustainability covers a large range of aspects, someone would expect to see these differences depicted in much of the earlier research related to the subject. The literature shows, however, that most of the studies undertaken up to now focus just on the effects of individual innovation aspects rather than on a more holistic approach. A large number of studies found a positive relationship between innovative environmental strategies and firms' performance (Hart, 1995; Nehrt, 1998, Dean and Brown, 1995; Porter and van der Linde, 1995a; Klassen and McLaughlin, 1996; Judge and Douglas, 1998; Sharma and Vredenburg, 1998; Klassen and Whybark, 1999). Firms use proactive environmental strategies to overcome regulatory issues, entry barriers and increase their capabilities as well as social acceptance (Dean and Brown, 1995; Hart, 1995; Russo and Fouts, 1997; Sharma and Vredenburg, 1998; Aragón-Correa and Sharma, 2003). Other studies report that highly innovative firms respond more to rapid and abrupt environmental changes (Schumpeter, 1942; Grossman and Helpman, 1994). Sustainable innovation is not only limited to overcoming regulation costs associated with environmental outcomes (Carrion-Flores and Innes 2010) but also has the potential to radically change the structures of corporate innovation 
(Aghion et al., 2015). This is mainly because innovation generates positive externalities and accelerates the diffusion and adoption of new, more sensitive, sustainable standards.

Another strand of literature reports a positive association between corporate governance and various aspects of innovation (R\&D, patents, and trademarks). Sandner and Block (2011) argue that $\mathrm{R} \& \mathrm{D}$, patent and trademark activity increase market value by protecting firms' knowledge and marketing assets. Firms through innovation transmit information and signal their value, increase transparency, and untimely increase their financial performance (Landes and Posner, 1987; Cockburn and Griliches, 1988; Besen and Raskind, 1991). This chapter follows the work of Heeley et al. (2007), Krasnikov et al. (2009), Sandner and Block (2011), Useche (2014), Bernstein (2015), and Block et al. (2014) who empirically examined the relationship between innovation and corporate sustainability. All the above yields substantial first-mover advantages that help firms to adapt and face regulators as allies by leading the way towards innovative corporate sustainability

\subsubsection{Hypothesis Development}

Based on the above discussion, we end up making testable predictions. Innovation is a significant factor that creates value and helps firms to turn the compliance arising from the regulations to opportunity but it is also idiosyncratic and has an economic cost and risk. Investment in innovation, however, improves the monitoring, raises awareness, develops risk prevention strategies and formulates tools for responding to different levels of market and technological challenges. In addition, innovation is an essential factor that enhances competitiveness, technological improvements, and helps firms to comply with the rules before they are legally enforced.

\section{H1: R\&D activity has a positive impact on sustainability}

The literature justifies that R\&D is linked positively with innovation. We hypothesize that $R \& D$ empowers companies to generate innovation, increase their competitiveness and formulate the tools to be more sustainable. 


\section{H2: Patents activity has a positive impact on sustainability}

The literature provides evidence that patents promote and secure new products and the firm's market position. Also, they enable companies to increase their standards and turn regulators into allies by leading the way. Firms' patents activity enhances and protects ESG possible outcomes. We hypothesize that patents have a positive impact on sustainability.

\section{H3: Trademarks activity has a positive impact on sustainability}

The literature documents that trademarks express the firm's soft intensive innovation about the product and enable companies to establish and secure a strong market position and customers' loyalty. Firms create trademarks at the early stage of sustainable development as a tool to capitalize and protect its possible outcomes. Therefore, we assume that trademarks of a protective and informative role have a positive impact on sustainability.

\section{H4: Firms' knowledge and organizational capital have a positive impact on sustainability}

We proxy the quality of innovation by using the firm's replacement cost of organization and knowledge capital. The former, that is the organizational capital, is an important corporate asset that contains diversified risk characteristics and comprises the value of a firm's capabilities such as organizational learning, infrastructure, organization processes, and knowledge to create products and services as well as the organization's philosophy. It provides information on internal knowledge (Atkeson and Kehoe,2005), strategies, technology and human capital (Eisfeldt and Papanikolaou,2013). The latter, that is the knowledge capital, comprises the value of the firm's knowledge and internal procedures. It represents the full body of knowledge and innovation that the firm possesses. It also contains human, relational, and structural capital such as experience, learning, and skills of employees. Chen (2008) and Boiral (2002) with their empirical results propose that it enhances a firm's efficiency and improves its competitive advantage Additional, knowledge capital is a catalyst that through knowledge transfer plays a significant role in the formation of better strategies which help the integration of tangible and intangible assets. From all the above, we expect that firms who invest in organizational and knowledge capital will face a higher probability to comply with regulations, reduce risk, increase the revenue streams, and create sustainability. So, we expect a positive relationship between knowledge capital, organizational capital, and sustainability. 


\subsection{Data and sample variables}

Our empirical analysis is based on a micro-level dataset of 1.048 US firms covering the period 2007- 2016. We solely focus on firms that report R\&D spending for the whole period of our analysis. Our variables come from different databases. Specifically, the dependent variable is firm sustainable performance (ESG) and is constructed based on a firm's risk index (Rep Risk Index, $\mathrm{RRI})$. We define $\mathrm{ESG}=100-\mathrm{RRI}$, where RRI is a proprietary risk metric that quantifies a company's exposure to environmental, social and governance matters. The RRI score is calculated based on several factors. It includes possible information source influences, frequency of criticisms, and the novelty and severity of the criticism. The RRI score ranges from zero (lowest) to 100 (highest) and the higher the value of the score, the higher the risk exposure. Accordingly, our dependent variable $(E S G)$ ranges from zero (lowest level of sustainability) to 100 (highest level of sustainability). Information on RRI is derived from the: RepRisk, Global Business Intelligence database. We also consider three major components of (ESG), namely the environmental (Environmental), social (Social) and corporate (Corporate). ${ }^{3}$ We obtain information for the firm' s sales (Sales) in millions of dollars from the Compustat database. To increase the sensitivity of our analysis we capture the firm's innovation using the following variables: (i) R\&D spending (millions of dollars) share to total sales ( $R \& D /$ Total Assets) which is the major asset of the innovation activity and represents the input of innovation; (ii) The number of patents of a firm share to total sales (Pat/Total Assets) as an output of innovation activity; iii) In addition to the innovation of the product, we use (Trademarks/Sales) to capture the firm's soft intensive innovation around the product. Therefore, we study the impact of innovation on firms' sustainable performance through the market establishment channel. Data on the former's measures come from the Compustat database, while for the latter from the Orbis Intellectual Property, a global company database, produced by the Bureau Van Dijk. Finally, following Peters and Taylor (2016) to study in a more holistic way a firm's innovation activity we use the replacement cost of a firm's organizational capital, knowledge

\footnotetext{
${ }^{3}$ Environmental sustainability relates to environmental policy and environmental management performance; Social sustainability concerns citizenship and socially responsible stakeholders' engagement, labor practice indicators, human capital development, knowledge management, and organizational learning, social reporting, talent attainment, and retention. Corporate governance sustainability as defined by Letza et al. (2004), is about the understanding and institutional arrangements for relationships among various economic actors and corporate participants who may have direct or indirect interest in a corporation, such as shareholders, directors/ managers, employees, creditors, suppliers, customers, local communities, government, and the general public.
} 
capital and intangible capital as a proxy of a firm's innovation. These measures come from the WRDS database Peters and Taylor (2016). To capture firms' market establishment, we use trademarks as a share of sales (TM/Sales) and data come from the Orbis database. Finally, we add a dummy for the 2008 financial crisis (Crisis) which takes the value of 1 for the years 2007, 2008 and zero otherwise. Table 2 provides the summary statistics of our sample variables over the examined period.

Table 2. Descriptive statistics

\begin{tabular}{llllll}
\hline Variable & Obs & Mean & Std. Dev. & Min & Max \\
\hline ESG & 6,802 & 91.33 & 11.65 & 28.5 & 100 \\
Sales/Total assets & 6,802 & 1.12 & .81 & 0 & 8.60 \\
(Sales/Total assets)2 & 6,802 & 1.93 & 3.83 & 0 & 74.07 \\
Sales growth (\%) & 6,802 & .24 & 6.10 & 0 & 474.81 \\
Advertising & 6,802 & 111.86 & 503.56 & 0 & 9729 \\
Firm Age & 6,802 & 36.47 & 29.85 & 2 & 159 \\
R\&D/Total assets (\%) & 6,802 & .08 & 1.43 & 0 & 93.08 \\
Patents/Total assets (\%) & 6,802 & .03 & 1.00 & 0 & 61.32 \\
Knowledge Capital/Total assets (\%) & 6,802 & .42 & 7.20 & 0 & 469.65 \\
Organization Capital/Total assets (\%) & 6,802 & .34 & 1.26 & 0 & 81.13 \\
TM/Sales (\%) & 6,802 & .03 & 1.04 & 0 & 53.57 \\
Crisis & 6,802 & .11 & .31 & 0 & 1 \\
\hline
\end{tabular}

This table reports descriptive statistics for a sample of 1,048 US firms. It provides the mean, standard deviation, minimum and maximum statistics for the sample as well as the total number of observations.

Table 2 documents descriptive statistics for our sample. Firms' sustainable performance (ESG) is on average quite high and about 91.33 (out of 100), and on average, firms grow by $0.24 \%$. When it comes to their innovation performance, firms spend, on average, $8 \%$ of their economic value on $\mathrm{R} \& \mathrm{D}$ investment. Respectively, the share of patents to total assets and trademarks to sales is $3 \%$. Last but not least, a firm's organization and knowledge capital replacement cost weighted by total assets is $34 \%$ and $42 \%$ respectively.

Figure 8 provides a visualization of the spatial distribution of sustainability across the US states over the sample period, 2007 - 2016. As we have the location of the firms and their sustainability performance, we were able to provide a spatial presentation of the firms in our sample. 
Figure 7. Spatial distribution of average sustainability performance for US firms, 2007-2016

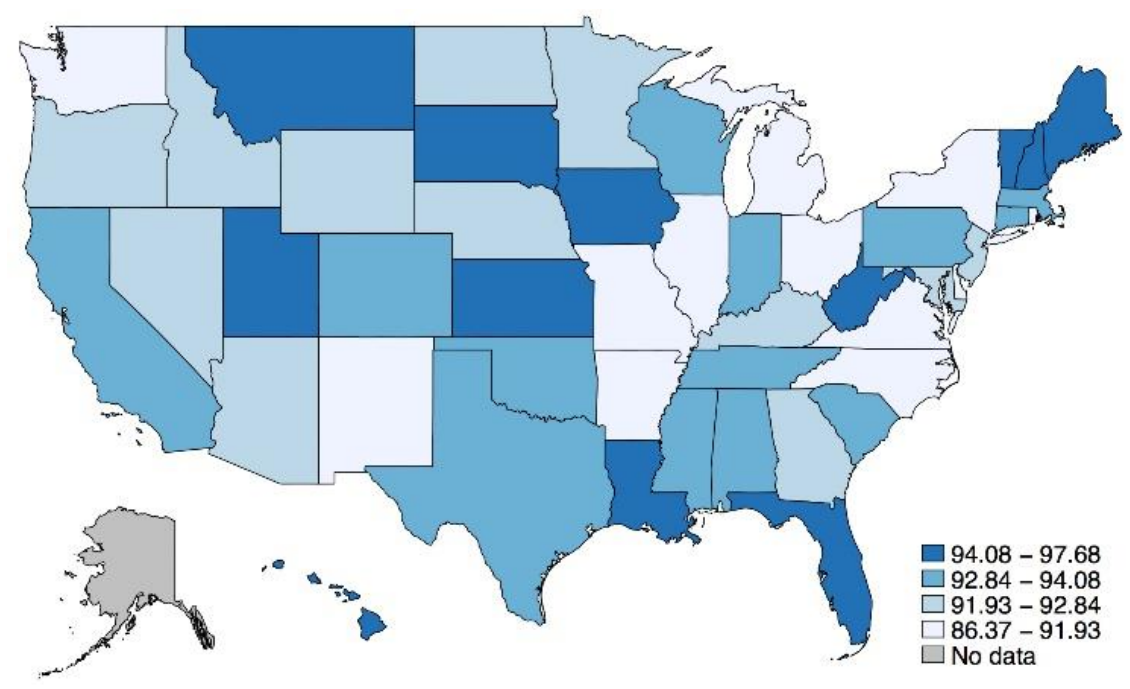

Figure 8, documents high concentration in sustainable firms with deep blue in the Northeast, Southeast, and central states, whereas in a very light blue (almost white) are states with the least sustainable performance. Comparing Figure 8 with Figure A.1, A.2 and A.3 in Appendix A can derive a positive relationship between sustainability, innovation, and firms' market establishment.

\subsection{Estimation strategy and methodology}

To support the basic research hypotheses (i.e., H1, H2, and H3) as expressed in a previous section of this chapter, our model follows closely Wagner (2010) description of which is given in brief as follows:

$S U S_{i t}=\beta_{i}+\beta_{1}(\text { Sales/Total assets })_{t-1}+\beta_{2}(\text { Sales/Total assets })_{t-1}^{2}+\beta_{3}(\text { Sales growth })_{t-1}+\beta_{4}(\text { FirmAge })_{t-1}+$

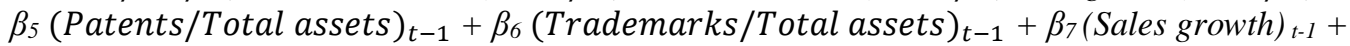
$\beta_{8}(R \& D / \text { Total assets })_{t-1}+\beta_{9}(\text { Advertising })_{t-1}+\beta_{10}(\text { Crisis_dummy })_{t-1}+\varepsilon_{i t}$

The following equation tries to explore the validity of hypothesis (H4):

$S U S_{i t}=\beta_{i}+\beta_{1}(\text { Sales/Total assets })_{t-1}+\beta_{2}(\text { Sales/Total assets })_{t-1}^{2}+\beta_{3}(\text { Sales growth })_{t-1}+\beta_{4}\left(\right.$ FirmAge ${ }_{t-1}+\beta_{5}$

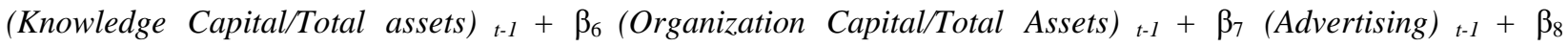
(Crisis_dummy) ${ }_{t-1}+\varepsilon_{\mathrm{it}}$ 
We use the following variation to study the effect of innovation efficiency on sustainability

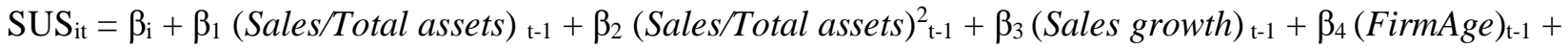
$\beta_{5}(\text { Crisis })_{\mathrm{t}-1}+\beta_{6}(\text { Advertising })_{\mathrm{t}-1+} \beta_{7}(\text { Patents/Total assets })_{\mathrm{t}-1}+\beta_{8}(\text { Trademarks/Sales })_{\mathrm{t}-1}+\beta_{9}(\text { Patents } / R \& D)_{\mathrm{t}-1}+$ $\beta_{10}(T M / R \& D)_{\mathrm{t}-1}+\varepsilon_{\mathrm{it}}$

where $t$ and $i$ are year and firm, respectively and $\varepsilon i t$ is i.i.d. error term.

The dependent variable is the firm's sustainability performance (ESG) index. To increase the sensitivity of our analysis we capture the firm's innovation using the following variables: (i) R\&D spending (millions of dollars) share to total sales ( $R \& D /$ Total Assets) which is the major asset of the innovation activity and represents the input of innovation; (ii) The number of patents of a firm to total assets (Pat/Total Assets) as an output of innovation activity; iii) In addition to the innovation of the product, we use the share of trademarks over sales (Trademarks/Sales) to capture the firm's soft intensive innovation on the product. Therefore, we study for the first time in the literature the impact of innovation on sustainability through the channel of firm's market establishment iv) Finally, following Peters and Taylor (2016) our research is also the first that uses the replacement cost of intangible capital, knowledge capital and organizational capital, to capture the aggregate effect of the quality of innovation on sustainability.

In line with Johnstone and Labonne (2009), we control for firms' sales over total assets (Sales/Total Assets); we use the quadratic term of the former variable (Sales/Total assets) ${ }^{2}$ to control for diminishing returns and the sales growth (Sales Growth) to control for profitability trend. Finally, we control for firm extroversion using advertising expenses (Advertising), firm age (FirmAge), and cold periods (Crisis Dummy) as in Gompers (1995) and Li (2008). In our analysis, we use both industry and year fixed effects.

Although we use a rich set of control variables there may be still unobserved variables that are missing from our model as well as problems that may arise from the heterogeneity between the firms in the sample. For this reason, we re-estimate our model by applying propensity matching score techniques (Rosenbaum and Rubin, 1983) to alleviate possible endogeneity issues ${ }^{4}$.

\footnotetext{
${ }^{4}$ Based on the propensity score matching method, we much firms that have sustainability above the sector average (i.e. treated firms) with those they do not (i.e. control firms) based on the control variables of our model specification.
} 
Specifically, we use a propensity to match firms that have innovation below the average of our sample with those above. In this way, we compare firms in matching samples that differ only in the level of innovation.

To secure our findings and check for robustness, we re-estimate our model with the two-stage least square method (2SLS). For this reason, we employ exogenous instruments to firm-specific characteristics (e.g. state R\&D weighted by firm size, yearly total Utility patents issued to state residents $^{5}$, and Higher Education R\&D performance ${ }^{6}$ ). In all the regressions, we keep the number of observations constant for a better comparison of the estimates and include industry and year fixed effects. Overall, our estimation strategy by using 2SLS with a rich set of instruments and propensity matching score techniques, secures that our results are not driven by endogeneity and reverse causality.

\subsection{Results and discussion}

Our first hypothesis argues that there is a positive relationship between sustainability and innovation. Table 3 presents the estimates of equation (1). Columns (1) and (2) refer to innovation investment, $R \& D$, columns ( 3 ) to (7) on the output of innovation in various specifications expressed by patents and trademarks. Finally, column (8) tests for the extroversion of innovation through advertising. Robust standards are included in the parentheses.

Table 3. Effect of Innovation on Sustainability (Dep. Var.: ESG)

\begin{tabular}{|c|c|c|c|c|c|c|c|c|c|}
\hline & (1) & (2) & (3) & (4) & (5) & (6) & (7) & (8) & (9) \\
\hline VARIABLES & ESG & ESG & ESG & & ESG & ESG & ESG & ESG & ESG \\
\hline
\end{tabular}

\footnotetext{
To further account that our results are not driven by different matching methods we use the three most common methods (Zhao 2004) which are based on the nearest neighbor, kernel, and stratification matching.

${ }^{5}$ Yearly totals for patents granted is determined by the residence of the first-named inventor

${ }^{6}$ The Higher Education Research and Development performance is a source of information for R\&D expenditures at

U.S. colleges and universities
} 


\begin{tabular}{|c|c|c|c|c|c|c|c|c|c|}
\hline & $(0.330)$ & $(0.330)$ & $(0.329)$ & $(0.330)$ & $(0.330)$ & $(0.328)$ & $(0.329)$ & $(0.326)$ & $(0.330)$ \\
\hline \multirow[t]{2}{*}{$(\text { Sales/Total assets })_{t-1}^{2}$} & -0.052 & -0.054 & -0.052 & -0.052 & -0.054 & -0.041 & -0.043 & -0.037 & -0.052 \\
\hline & $(0.059)$ & $(0.059)$ & $(0.059)$ & $(0.059)$ & $(0.059)$ & $(0.059)$ & $(0.059)$ & $(0.059)$ & $(0.059)$ \\
\hline \multirow[t]{2}{*}{ (Sales growth $_{t-1}$} & $0.026^{*}$ & $0.026^{*}$ & $0.026^{*}$ & $0.026^{*}$ & $0.026^{*}$ & $0.026^{*}$ & $0.026^{*}$ & $0.025^{*}$ & $0.027 *$ \\
\hline & $(0.015)$ & $(0.015)$ & $(0.015)$ & $(0.015)$ & $(0.015)$ & $(0.015)$ & $(0.015)$ & $(0.015)$ & $(0.015)$ \\
\hline \multirow[t]{2}{*}{$(\text { FirmAge })_{t-1}$} & $-0.067 * * *$ & $-0.067 * * *$ & $-0.067 * * *$ & $-0.067 * * *$ & $-0.067 * * *$ & $-0.063 * * *$ & $-0.063 * * *$ & $-0.065 * * *$ & $-0.067 * * *$ \\
\hline & $(0.005)$ & $(0.005)$ & $(0.005)$ & $(0.005)$ & $(0.005)$ & $(0.005)$ & $(0.005)$ & $(0.005)$ & $(0.005)$ \\
\hline \multirow[t]{2}{*}{ Crisis } & $6.919 * * *$ & $6.915^{* * * *}$ & $6.920 * * *$ & $6.916 * * *$ & $6.916^{* * * *}$ & $7.199 * * *$ & $7.196 * * *$ & $7.334 * * *$ & $6.909 * * *$ \\
\hline & $(0.504)$ & $(0.504)$ & $(0.504)$ & $(0.504)$ & $(0.504)$ & $(0.501)$ & $(0.501)$ & $(0.498)$ & $(0.505)$ \\
\hline \multirow[t]{2}{*}{$(\text { Advertising })_{t-1}$} & $-0.008 * * *$ & $-0.008 * * *$ & $-0.008 * * *$ & $-0.008 * * *$ & $-0.008 * * *$ & $-0.008 * * *$ & $-0.008 * * *$ & $-0.010 * * *$ & $-0.008 * * *$ \\
\hline & $(0.001)$ & $(0.001)$ & $(0.001)$ & $(0.001)$ & $(0.001)$ & $(0.001)$ & $(0.001)$ & $(0.001)$ & $(0.001)$ \\
\hline \multirow[t]{2}{*}{ (Patents/Total assets) $_{t-1}$} & & & $0.128 * * *$ & & $0.128 * * *$ & $0.134 * * *$ & $0.133 * * *$ & $0.127 * * *$ & $0.127 * * *$ \\
\hline & & & $(0.033)$ & & $(0.033)$ & $(0.036)$ & $(0.036)$ & $(0.034)$ & $(0.032)$ \\
\hline \multirow{2}{*}{$(R \& D / \text { Total assets })_{t-1}$} & $0.088^{* *}$ & $0.087 * *$ & & & & & & & \\
\hline & $(0.038)$ & $(0.038)$ & & & & & & & \\
\hline \multirow[t]{2}{*}{$(\text { TM/Sales })_{t-1}$} & & $0.077 * * *$ & & $0.078 * * *$ & $0.078 * * *$ & & $0.072 * * *$ & $0.067 * * *$ & $0.076^{* * *}$ \\
\hline & & $(0.019)$ & & $(0.019)$ & $(0.019)$ & & $(0.019)$ & $(0.019)$ & $(0.019)$ \\
\hline \multirow{2}{*}{$\begin{array}{l}(\text { Patents/Total assets })_{t-1} \\
x(\text { Advertising })_{t-1}\end{array}$} & & & & & & & & $0.302 * * *$ & \\
\hline & & & & & & & & $(0.061)$ & \\
\hline \multirow[t]{2}{*}{$(T M / R \& D)_{t-1}$} & & & & & & & & & $0.271 * * *$ \\
\hline & & & & & & & & & $(0.097)$ \\
\hline \multirow[t]{2}{*}{$(\text { Patents/ } R \& D)_{t-1}$} & & & & & & & & & 0.045 \\
\hline & & & & & & & & & $(0.080)$ \\
\hline Observations & 6,802 & 6,802 & 6,802 & 6,802 & 6,802 & 6,802 & 6,802 & 6,802 & 6,802 \\
\hline$R$-squared & 0.288 & 0.288 & 0.288 & 0.288 & 0.288 & 0.300 & 0.300 & 0.314 & 0.289 \\
\hline Year FE & YES & YES & YES & YES & YES & YES & YES & YES & YES \\
\hline Sector FE & YES & YES & YES & YES & YES & YES & YES & YES & YES \\
\hline ROBUST & YES & YES & YES & YES & YES & YES & YES & YES & YES \\
\hline
\end{tabular}

The table reports coefficient estimates and standard errors of regressions based on equations (1) and (3). The dependent variable is the firm's sustainability (ESG). All variables are defined in Table A1. The estimation method is OLS with robust standard errors. All models include year and industry fixed effects. An asterisk indicates significance at the 10\% level; two indicate significance at the 5\% level; three indicate significance at the $1 \%$ level.

The key explanatory variables are (R\&D/Total Assets), (Patents/Total assets) and (TM/Sales). In line with Johnstone and Labonne (2009), we control for firms' sales over total assets (Sales/Total Assets); we use the quadratic term of the former variable (Sales/Total assets) ${ }^{2}$ to control for diminishing returns and the sales growth (Salesgrowth) to control for profitability trend. Finally, we control for firm extroversion using advertising expenses (Advertising), firm age (FirmAge), and cold periods (Crisis_dummy) as in Gompers (1995) and Li (2008). The response variable is the 
firm's sustainability performance, $(E S G)$. In our analysis, we use both industry and year fixed effects.

As Table 3 shows, estimates are quite stable and statistically robust across all the specifications. Sales (Sales/Total assets) have a positive impact on sustainability as a one percent increase in sales results in 0.75 (column 8) to 0.88 (column 2) units of increase of the firm's sustainability performance ${ }^{7}$. This finding is in alignment with prior literature (see for example Hirsch, 1990; Wagner, 2010). Further, we examine the presence of no linear effects of sales on sustainability by using the quadratic term of sales (Sales/Total assets) ${ }^{2}$. We expect to find a negative association with sustainability, as the marginal effect is negative at the data means but we take no statistically significant effect. In other words, we argue that non-linear effects are not present and monotonicity prevails. Growth in sales (Sales growth) is generally found to be positively correlated with a firm's value (Hirsch, 1990). Specifically, we argue that when a firm's sales growth is relatively high, corporate sustainability is positively related to firm value. In contrast, when a firm's sales growth is relatively low, the magnitude of the positive relationship is reduced. The higher the sales growth, the stronger the relationship will be between corporate sustainability and firm value. The possible managerial implication for this result is that some investors may be hesitant about a firm's sustainable strategies which, in their beliefs, will increase a firm's production and operation costs and thus reduce sales. Therefore, good news on sales growth for a sustainable firm will stimulate investors to give a higher valuation. Investing in $R \& D$ activity is associated with an increase of 0.08 of the firm's sustainability, as the coefficient ( $R \& D /$ Total assets) in columns (1) and (2) indicate. Investing in patents also increases the sustainability performance of a firm. An increase of patent activity (PAT/ Total assets) relates to an increase of a firm's performance from 0.127 to 0.134 percent as it is shown in columns (3) and (5) to (8) respectively. A firm's reconcilability and penetration in the market -both proxied by trademarks (TM/Sales) in columns (2) to (4) and (7) to (8) are important factors for a firm's sustainability. Even when we include hard intensive innovation measures such as R\&D and patents together results do not alter and trademarks effect plays a significant role in firms' sustainability that ranges from 0.67 to 0.77 . The financial crisis of 2008 ,

\footnotetext{
${ }^{7}$ In level-log specifications, as it is ours, estimates of log regressors are interpreted as follows: If regressor $x$ increases by one percent, one expects regressant $y$ to increase by $(\beta 1 / 100)$ units of $y[\Delta y=(\beta 1 / 100) \% \Delta x]$.
} 
as expected, had a positive impact on firms' sustainability. ${ }^{8}$ Last but not least, as column (8) presents the effect of advertising on innovation increases sustainability. Consumers are making adjustments in their preferences and strongly support companies that are more sustainable conscious.

In column (9) we use an alternative model specification to study the impact of innovation efficiency on sustainability. ${ }^{9}$ Therefore, we construct the variables (Patents/R\&D and $(T M / R \& D)$ as the shares of patents and trademarks to $\mathrm{R} \& \mathrm{D}$ to capture hard and soft intensive innovation efficiency respectively (see Hirshleifer, 2013). These measures are not in general highly correlated with the innovation predictors (Chan, 2001; Gu, 2005) that we have already used therefore their usage may reveal useful incremental information.

Based on the above considerations, we estimate equation (3). The results document that soft intensive innovation efficiency matters (see Table A2). The intuition behind this finding is that the ultimate competitive advantage in terms of sustainability is capitalized from policies and methods that companies develop. This finding is in line with the existing literature (McWilliams and Siegel, 2001; Sen and Bhattacharya, 2001; Godfrey, 2005).

Next, we split the response variable (ESG) into its three major components namely environmental (EP), social (SP) and governance (GP). As Table 4 shows, columns (1) to (4) and columns (5) to (7) present the effect of innovation expressed by R\&D patents and trademarks respectively on the major components of sustainability.

Table 4. Effect of Innovation on the three major sustainability (ESG) components namely environmental (EP), social (SP) and governance (GP)

\begin{tabular}{|c|c|c|c|c|c|c|c|}
\hline VARIABLES & $\begin{array}{c}(1) \\
\text { ESG }\end{array}$ & $\begin{array}{l}(2) \\
\text { EP }\end{array}$ & $\begin{array}{l}\text { (3) } \\
\text { SP }\end{array}$ & $\begin{array}{l}\text { (4) } \\
\text { GP }\end{array}$ & $\begin{array}{l}(5) \\
\text { EP }\end{array}$ & $\begin{array}{l}\text { (6) } \\
\text { SP }\end{array}$ & $\begin{array}{l}\text { (7) } \\
\text { GP }\end{array}$ \\
\hline (Sales/Total assets $_{t-1}$ & $\begin{array}{c}0.871 * * * \\
(0.330)\end{array}$ & $\begin{array}{c}0.035 * * * \\
(0.009)\end{array}$ & $\begin{array}{c}-0.004 \\
(0.008)\end{array}$ & $\begin{array}{c}0.048 * * * \\
(0.009)\end{array}$ & $\begin{array}{c}0.035^{* * *} * \\
(0.009)\end{array}$ & $\begin{array}{c}-0.004 \\
(0.008)\end{array}$ & $\begin{array}{c}0.048 * * * \\
(0.009)\end{array}$ \\
\hline$(\text { Sales/Total assets })_{t-1}^{2}$ & -0.052 & $-0.006 * * *$ & $0.004 * * *$ & $-0.005 * * *$ & $-0.006 * * *$ & $0.004 * * *$ & $-0.005 * * *$ \\
\hline
\end{tabular}

\footnotetext{
${ }^{8}$ Firms use sustainability as a risk mitigation tool.

${ }^{9}$ Is the maximization of the output produced from the invested R\&D improving innovation performance and enhancing competitiveness?
} 


\begin{tabular}{|c|c|c|c|c|c|c|c|}
\hline & $(0.059)$ & $(0.002)$ & $(0.001)$ & $(0.002)$ & $(0.002)$ & $(0.001)$ & $(0.002)$ \\
\hline \multirow{2}{*}{$(\text { Sales growth })_{t-1}$} & $0.026^{*}$ & 0.000 & 0.000 & $0.001 * *$ & 0.000 & 0.000 & $0.001 * *$ \\
\hline & $(0.015)$ & $(0.000)$ & $(0.000)$ & $(0.000)$ & $(0.000)$ & $(0.000)$ & $(0.001)$ \\
\hline \multirow[t]{2}{*}{$(\text { Advertising })_{t-1}$} & $-0.008 * * *$ & $-0.000 * * *$ & $-0.000 * * *$ & $-0.000 * * *$ & $-0.000 * * *$ & $-0.000 * * *$ & $-0.000 * * *$ \\
\hline & $(0.001)$ & $(0.000)$ & $(0.000)$ & $(0.000)$ & $(0.000)$ & $(0.000)$ & $(0.000)$ \\
\hline \multirow[t]{2}{*}{$(\text { FirmAge })_{t-1}$} & $-0.067 * * *$ & $-0.001 * * *$ & $-0.001 * * *$ & $-0.000 * * *$ & $-0.001 * * *$ & $-0.001 * * *$ & $-0.000 * * *$ \\
\hline & $(0.005)$ & $(0.000)$ & $(0.000)$ & $(0.000)$ & $(0.000)$ & $(0.000)$ & $(0.000)$ \\
\hline \multirow[t]{2}{*}{ Crisis } & $6.919 * * *$ & 0.007 & $0.130 * * *$ & $0.208 * * *$ & 0.007 & $0.130 * * *$ & $0.208 * * *$ \\
\hline & $(0.504)$ & $(0.009)$ & $(0.014)$ & $(0.013)$ & $(0.009)$ & $(0.014)$ & $(0.013)$ \\
\hline \multirow[t]{2}{*}{$(\text { Patents/Total assets })_{t-1}$} & & & & & $0.001 * * *$ & $0.001 * *$ & $0.005 * * *$ \\
\hline & & & & & $(0.000)$ & $(0.001)$ & $(0.001)$ \\
\hline \multirow[t]{2}{*}{$(\text { TM/Sales })_{t-1}$} & & & & & $0.001 * * *$ & 0.001 & $0.003 * * *$ \\
\hline & & & & & $(0.000)$ & $(0.001)$ & $(0.001)$ \\
\hline \multirow[t]{2}{*}{$(R \& D / \text { Total assets })_{t-1}$} & $0.088 * *$ & $0.001 * *$ & 0.001 & $0.003 * * *$ & & & \\
\hline & $(0.038)$ & $(0.000)$ & $(0.001)$ & $(0.001)$ & & & \\
\hline Observations & 6,802 & 6,802 & 6,802 & 6,802 & 6,802 & 6,802 & 6,802 \\
\hline$R$-squared & 0.288 & 0.134 & 0.108 & 0.129 & 0.134 & 0.108 & 0.129 \\
\hline Year FE & YES & YES & YES & YES & YES & YES & YES \\
\hline Sector FE & YES & YES & YES & YES & YES & YES & YES \\
\hline ROBUST & YES & YES & YES & YES & YES & YES & YES \\
\hline
\end{tabular}

The table reports coefficient estimates and standard errors of regressions based on equations (1). The dependent variable is the firm's sustainability (ESG) and its components namely environmental $(E P)$, social $(S P)$ and governance $(G P)$. All variables are defined in Table A1. The estimation method is OLS with robust standard errors. All models include year and industry fixed effects. An asterisk indicates significance at the $10 \%$ level; two indicate significance at the $5 \%$ level; three indicate significance at the $1 \%$ level.

As sales become larger, a firm's sustainability increases at a decreasing rate until it reaches a maximum level; this finding also aligns with existing literature (Wagner, 2010). In the next stage, we check for non-linear effects of sales on sustainability by using the quadratic term of sales (Sales/Total assets) ${ }^{2}$, we find a negative and statistically significant correlation with all components of sustainability. The dynamics of the market, proxied by the growth of sales (Salesgrowth), do not play an important role in environmental (EP) and social (SP) component but for governance (GP) is statistically significant. We find a positive relationship between innovation proxy by R\&D, patents and trademarks and firms' sustainable performance (ESG). One can note that although the coefficients are different in size compared to those reported in Table 3, their relative significance remained unaltered. One reason for this might be attributed to the fact that firms are less motivated to work on social aspects of sustainability as regulation or taxation are more relevant to the other two aspects of the ESG.

In the next stage, we study the impact of innovation quality on a firm's corporate sustainability which is a direct test that corresponds to our hypothesis (H4). The structure of Table 4 resembles that of Table 3, but we shed light on the quality aspect of innovation proxy by its value. We use 
knowledge capital, organization capital and their aggregate sum intangible capital to measure the value of innovation.

Table 5. Effect of the value of Innovation on Sustainability (Dep. Var.: ESG)

\begin{tabular}{|c|c|c|c|c|c|c|}
\hline VARIABLES & $\begin{array}{c}(1) \\
\text { ESG }\end{array}$ & $\begin{array}{c}(2) \\
\text { ESG }\end{array}$ & $\begin{array}{c}(3) \\
\text { ESG }\end{array}$ & $\begin{array}{c}(4) \\
\text { ESG }\end{array}$ & $\begin{array}{c}5) \\
\text { ESG }\end{array}$ & $\begin{array}{c}6) \\
\text { ESG }\end{array}$ \\
\hline (Sales/Total assets) $_{t-1}$ & $\begin{array}{c}0.870 * * * \\
(0.329)\end{array}$ & $\begin{array}{c}0.871 * * * \\
(0.330)\end{array}$ & $\begin{array}{c}0.799 * * \\
(0.331)\end{array}$ & $\begin{array}{c}0.891 * * * \\
(0.329)\end{array}$ & $\begin{array}{c}0.902 * * * \\
(0.331)\end{array}$ & $\begin{array}{c}0.741 * * \\
(0.334)\end{array}$ \\
\hline$(\text { Sales/Total assets })_{t-1}^{2}$ & $\begin{array}{l}-0.052 \\
(0.059)\end{array}$ & $\begin{array}{l}-0.052 \\
(0.059)\end{array}$ & $\begin{array}{l}-0.045 \\
(0.059)\end{array}$ & $\begin{array}{l}-0.055 \\
(0.059)\end{array}$ & $\begin{array}{l}-0.056 \\
(0.059)\end{array}$ & $\begin{array}{l}-0.038 \\
(0.059)\end{array}$ \\
\hline (Sales growth $_{t-1}$ & $\begin{array}{l}0.026^{*} \\
(0.015)\end{array}$ & $\begin{array}{l}0.026^{*} \\
(0.015)\end{array}$ & $\begin{array}{l}0.026^{*} \\
(0.015)\end{array}$ & $\begin{array}{l}0.024^{*} \\
(0.014)\end{array}$ & $\begin{array}{l}0.025^{*} \\
(0.014)\end{array}$ & $\begin{array}{l}0.027 * \\
(0.015)\end{array}$ \\
\hline$(\text { FirmAge })_{t-1}$ & $\begin{array}{c}-0.067 * * * \\
(0.005)\end{array}$ & $\begin{array}{c}-0.067 * * * \\
(0.005)\end{array}$ & $\begin{array}{c}-0.067 * * * \\
(0.005)\end{array}$ & $\begin{array}{c}-0.067 * * * \\
(0.005)\end{array}$ & $\begin{array}{c}-0.067 * * * \\
(0.005)\end{array}$ & $\begin{array}{c}-0.067 * * * \\
(0.005)\end{array}$ \\
\hline Crisis & $\begin{array}{c}6.920 * * * \\
(0.504)\end{array}$ & $\begin{array}{c}6.919 * * * \\
(0.504)\end{array}$ & $\begin{array}{c}6.929 * * * \\
(0.504)\end{array}$ & $\begin{array}{c}5.777 * * * \\
(0.652)\end{array}$ & $\begin{array}{c}6.710 * * * \\
(0.529)\end{array}$ & $\begin{array}{c}6.339 * * * \\
(0.614)\end{array}$ \\
\hline$(\text { Advertising })_{t-1}$ & $\begin{array}{c}-0.008 * * * \\
(0.001)\end{array}$ & $\begin{array}{c}-0.008 * * * \\
(0.001)\end{array}$ & $\begin{array}{c}-0.008 * * * \\
(0.001)\end{array}$ & $\begin{array}{c}-0.008 * * * \\
(0.001)\end{array}$ & $\begin{array}{c}-0.008 * * * \\
(0.001)\end{array}$ & $\begin{array}{c}-0.008 * * * \\
(0.001)\end{array}$ \\
\hline (Intangible Capital/Total assets) $_{t-1}$ & $\begin{array}{c}0.019 \text { ** } \\
(0.009)\end{array}$ & & & $\begin{array}{c}0.019 * * \\
(0.009)\end{array}$ & & \\
\hline (Organization Capital/Total assets) $_{t-1}$ & & & $\begin{array}{l}0.272 * \\
(0.154)\end{array}$ & & & $\begin{array}{l}0.264^{*} \\
(0.150)\end{array}$ \\
\hline$(\text { Knowledge Capital/Total assets) })_{t-1}$ & & $\begin{array}{c}0.018 * * \\
(0.008)\end{array}$ & & & $\begin{array}{c}0.017 * * \\
(0.008)\end{array}$ & \\
\hline $\begin{array}{l}\left(\text { Intangible Capital/Total assets) }{ }_{t-1}\right. \\
x \text { Crisis }\end{array}$ & & & & $\begin{array}{l}1.588 * * * \\
(0.435)\end{array}$ & & \\
\hline $\begin{array}{l}\text { (Knowledge Capital/Total assets) }{ }_{t-1} \\
x \text { Crisis }\end{array}$ & & & & & $\begin{array}{c}0.912 * * * \\
(0.297)\end{array}$ & \\
\hline $\begin{array}{l}\left(\text { Organization Capital/Total assets) }{ }_{t-1}\right. \\
x \text { Crisis }\end{array}$ & & & & & & $\begin{array}{l}2.075 * * \\
(1.009)\end{array}$ \\
\hline Observations & 6,802 & 6,802 & 6,802 & 6,802 & 6,802 & 6,802 \\
\hline$R$-squared & 0.288 & 0.288 & 0.289 & 0.289 & 0.288 & 0.289 \\
\hline Year FE & YES & YES & YES & YES & YES & YES \\
\hline Sector FE & YES & YES & YES & YES & YES & YES \\
\hline ROBUST & YES & YES & YES & YES & YES & YES \\
\hline
\end{tabular}

The table reports coefficient estimates and standard errors of regressions based on equations (2). The dependent variable is the firm's sustainability (ESG). All variables are defined in Table A1. The estimation method is OLS with robust standard errors. All models include year and industry fixed effects. An asterisk indicates significance at the $10 \%$ level; two indicate significance at the 5\% level; three indicate significance at the $1 \%$ level.

In line with Johnstone and Labonne (2009), we control for firms' sales over total assets (Sales/Total Assets); we use the quadratic term of the former variable (Sales/Total assets) ${ }^{2}$ to control for 
diminishing returns and the sales growth (Salesgrowth) to control for profitability trend. Finally, we control for firm extroversion using advertising expenses (Advertising), firm age (FirmAge), and cold periods (Crisis_dummy) as in Gompers (1995) and Li (2008). The response variable is the firm's sustainability performance, $(E S G)$. In our analysis, we use both industry and year fixed effects. The results indicate that the value of innovation measured by organization, knowledge, and intangible capital has a positive impact on the firm's sustainability. We find that coefficients of (Organization Capital/Total assets) and (Knowledge Capital/Total assets) are positive and statistically significant as well as their aggregate effect expressed by the coefficient of (intangible capital/total assets). Besides, in crisis periods this impact becomes significantly stronger which probably happens because companies through target innovation activity invest in their resources and competencies resulting in higher sustainable performance and ultimately better resilience. The results are in line with the theoretical arguments of (section 5.1) and support the argument that asset accumulation is not only vital for the firm's growth and market establishment but and for its sustainable performance. The value generated by innovation, in particular, is highly beneficial for a firm's sustainability, as via ESG strategy differentiation a firm can penetrate in the market. In sum, we document in this section that firms with higher innovation quality are associated with better (ESG) performance and this effect in cold periods becomes even stronger.

\subsection{Robustness checks}

This section presents the necessary robustness of our findings. One could argue that the results may be driven by endogeneity issues. To alleviate such concerns and address possible feedback effects between innovation and sustainability, we deploy two techniques: a) instrumental analysis and b) propensity matching score. These techniques are described below.

\subsubsection{Instrumental Analysis}

We first perform two-stage least square (2SLS) estimation. We include the same control variables and industry year fixed effect as in our corresponding baseline regressions. We use as instruments the state R\&D weighted by firm size; the yearly total utility patents issued to state residents and the Higher education R\&D performance. The intuition in using these variables comes from the fact that our sample includes firms from states with different innovation activities, institutional 
characteristics, and regulations. These characteristics play a crucial role in shaping a firm's innovation activity. The former instruments, are exogenous to the firm's specific characteristics so we expect the results to be causal. Our equations will be exactly identified. We use the underidentification test by Kleibergen and Paap to check if the number of instruments is adequate compared with the number of the endogenous variables. The null hypothesis is that there is underidentification and is required a value lower than 0.05 to reject the null hypothesis at the $5 \%$ level. We use the Hansen over-identification test to test for possible correlation between the instruments and the error term. If there is any correlation then the instruments are not treated as acceptable. Under the null hypothesis over identifying restrictions are valid, and is required a higher value than 0.05 to reject the null hypothesis at the $5 \%$ level. We check for the instrument's explanatory powers by using a weak identification test. In this test, we compare the critical values with Cragg-Donald Wald F statistic and if any of them is greater than that, then the instruments are week and do not have explanatory power. Finally, we use Durbin and Wu-Housman tests to check if the variables are exogenous or endogenous. These statistics have very low $p$-value we correctly performed 2 sls. In Table 6, we report our instrumental variable results.

Table 6. Instrumental Variable Analysis on the Relationship Between Innovation and Sustainability

\begin{tabular}{|c|c|c|c|c|c|}
\hline & (1) & (2) & (3) & (4) & (5) \\
\hline VARIABLES & ESG & ESG & ESG & ESG & ESG \\
\hline \multirow{2}{*}{$(\text { Sales/Total assets })_{t-1}$} & 0.352 & 0.293 & 0.031 & 0.345 & 0.308 \\
\hline & $(0.365)$ & $(0.363)$ & $(0.361)$ & $(0.365)$ & $(0.363)$ \\
\hline \multirow[t]{2}{*}{$(\text { Sales/Total assets })_{t-1}^{2}$} & 0.017 & 0.025 & 0.053 & 0.018 & 0.022 \\
\hline & $(0.069)$ & $(0.069)$ & $(0.068)$ & $(0.069)$ & $(0.069)$ \\
\hline \multirow[t]{2}{*}{$(\text { Sales growth })_{t-1}$} & 0.031 & 0.031 & 0.031 & 0.031 & 0.031 \\
\hline & $(0.019)$ & $(0.019)$ & $(0.019)$ & $(0.019)$ & (0.019) \\
\hline \multirow[t]{2}{*}{$(\text { FirmAge })_{t-1}$} & $-0.064 * * *$ & $-0.064 * * *$ & $-0.064 * * *$ & $-0.064 * * *$ & $-0.064 * * *$ \\
\hline & $(0.004)$ & $(0.004)$ & $(0.004)$ & $(0.004)$ & $(0.004)$ \\
\hline \multirow[t]{2}{*}{ Crisis } & $7.122 * * *$ & $7.124 * * *$ & $7.119 * * *$ & $7.119 * * *$ & $7.151 * * *$ \\
\hline & $(0.494)$ & $(0.494)$ & $(0.494)$ & $(0.494)$ & $(0.520)$ \\
\hline \multirow[t]{2}{*}{$(\text { Advertising })_{t-1}$} & $-0.009 * * *$ & $-0.009 * * *$ & $-0.009 * * *$ & $-0.009 * * *$ & $-0.009 * * *$ \\
\hline & $(0.000)$ & $(0.000)$ & $(0.000)$ & $(0.000)$ & $(0.000)$ \\
\hline \multirow[t]{2}{*}{$(\text { Patents/Total assets })_{t-1}$} & & $0.903 * * *$ & (0.519) & $(0.520)$ & \\
\hline & & $(0.248)$ & & & \\
\hline \multirow[t]{2}{*}{$(R \& D / \text { Total assets })_{t-1}$} & $0.739 * * *$ & & & & \\
\hline & $(0.204)$ & & & & \\
\hline
\end{tabular}


(Intangible Capital/Total assets) $_{t-1}$

(Knowledge Capital/Total assets) ${ }_{t-1}$

(Organization Capital/Total assets) ${ }_{t}$

$0.122 * * *$

(0.033)

$0.144 * * *$

$(0.040)$

$0.781 * * *$

$(0.217)$

\begin{tabular}{lccccc} 
Observations & 6,802 & 6,802 & 6,802 & 6,802 & 6,802 \\
$R$-squared & 0.275 & 0.276 & 0.279 & 0.275 & 0.276 \\
Year FE & YES & YES & YES & YES & YES \\
Industry FE & YES & YES & YES & YES & YES \\
\hline Under-Identification Test & 0.000 & 0.000 & 0.000 & 0.000 & 0.000 \\
Weak-Identification Test & 46.879 & 68.095 & 53.388 & 49.545 & 50.733 \\
& $(13.91)$ & $(13.91)$ & $(13.91)$ & $(13.91)$ & $(13.91)$ \\
Over-Identification Test & 0.229 & 0.237 & 0.194 & 0.238 & 0.242 \\
Durbin (score) & 0.000 & 0.000 & 0.00 & 0.000 & 0.000 \\
Wu-Hausman & 0.000 & 0.000 & 0.00 & 0.000 & 0.000
\end{tabular}

Notes: This table documents 2sls estimates and stander errors (in parentheses) based on equations (1) and (2). Columns 1 focus only on firms in R\&D activity; Column 2 considers the firm's patent activity. Column 3 and column 4 document evidence for the value of innovation expressed by Knowledge Capital and Organization Capital. In all regressions, we keep the number of observations constant for a better comparison of the estimates and include industry and year fixed effects. All models include year and industry fixed effects. In all models, the instrumental variables are stated higher education R\&D performance, utility patents issue to state and state total industry R\&D performance. UnderIdentification Test reports the $p$-value of the LM test by Kleibergen and Paap, which requires a value lower than 0.05 to reject the null hypothesis at the 5\% level. Weak-Identification Test reports the Wald $F$-statistic test by Kleibergen and Paap, which must be higher than its critical value included in parentheses to reject the null. Over-Identification Test reports the $p$-value of the over-identification test by Hansen, which requires a value higher than 0.05 to reject the null hypothesis at the 5\% level. Durbin and Wu-Housman statistics have very low $p$-value so correct performed 2sls. An asterisk indicates significance at the $10 \%$ level; two indicate significance at the $5 \%$ level; three indicate significance at the $1 \%$ level.

Focusing on the estimates of our interest, both quantity and quality measures of innovation continue to play an important role in firms' sustainable performance. We find that the coefficients of our instrumental analysis are positive and significant at $1 \%$ level across all proxies of innovation and associated with an increase of 0,14 to 0,9 of the firm's sustainability depending on the innovation proxy we use. In sum, the output of IV analysis indicates that the results of our baseline are causal which supports our hypothesis $\mathrm{H} 1$ to $\mathrm{H} 4$.

\subsubsection{Propensity Matching}

A second approach to alleviating possible endogeneity concerns involves propensity score matching analysis. The idea behind this, is to compare ESG performance of similar firm's along 
other dimensions with only differences in their innovation profile. We compare with propensity score matching method firms that have innovation over the average with those who do not. In order to do it, we construct dummy files (DummyR\&D, DummyPatents, DummyTrademarks, DummyKnowledgeCapital, DummyOrganization Capital) that take value 1 if innovation aspect is over the average and zero otherwise. We match firms with similar characteristics across the control variables, so any observed difference across the firm is then attributed to their innovation behavior. Our results provide evidence that in matching samples, controlling for all the other factors and with only different the level of innovation, firms with innovation activity over the average have around 0.996 to 3.907 times more sustainable performance depending on innovation aspect and the matching method.

Table 7. Robustness results with Propensity Score Matching

Panel A: This table presents propensity for Dependent Variable: Sustainability

\begin{tabular}{|c|c|c|c|c|c|c|c|c|c|}
\hline \multirow[t]{2}{*}{ Treatment Variable: } & \multicolumn{3}{|c|}{$\mathrm{R} \& \mathrm{D}$} & \multicolumn{3}{|c|}{ Patents } & \multicolumn{3}{|c|}{ Trademarks } \\
\hline & (1) & (2) & (3) & (4) & $(5)$ & $\overline{(6)}$ & (7) & (8) & $\overline{(9)}$ \\
\hline Nearest neighbor & $\begin{array}{c}3.907 * * * \\
(0.299)\end{array}$ & & & $\begin{array}{c}2.650 * * * \\
(0.922)\end{array}$ & & & $\begin{array}{c}0.651 \\
(1.041)\end{array}$ & & \\
\hline Kernel & & $\begin{array}{c}3.907 * * * \\
(0.269)\end{array}$ & & & $\begin{array}{c}2.829 * * * \\
(0.229)\end{array}$ & & & $\begin{array}{r}2.995 * * * \\
(0.645)\end{array}$ & \\
\hline Stratification & & & $\begin{array}{c}3.907 * * * \\
(0.102)\end{array}$ & & & $\begin{array}{c}2.200^{* * *} \\
(0.309)\end{array}$ & & & $\begin{array}{c}1.691 * * * \\
(0.796)\end{array}$ \\
\hline Observations & 6,802 & 6,802 & 6,802 & $\begin{array}{c}2.650 * * * \\
6,802\end{array}$ & 6,802 & 6,802 & 6,802 & 6,802 & 6,802 \\
\hline$\frac{\text { Panel B: This ta }}{\text { Dependent Variable: }}$ & $\frac{\text { resents pro }}{\text { ainability }}$ & pensity for & & & & & & & \\
\hline Treatment Variable: & & & owledge $\mathrm{C}$ & apital & & & rganizatic & Capital & \\
\hline & & (1) & $(2)$ & & (3) & (4) & $(5)$ & & (6) \\
\hline Nearest neighbor & & $\begin{array}{c}1.522 * * * \\
(0.518)\end{array}$ & & & & $\begin{array}{c}1.317 * * \\
(0.605)\end{array}$ & & & \\
\hline Kernel & & & $\begin{array}{r}1.908 \\
(0.47\end{array}$ & & & & $\begin{array}{r}1.08 \\
(0.2\end{array}$ & & \\
\hline Stratification & & & & & $\begin{array}{l}479 * * * \\
(0.302)\end{array}$ & & & & $\begin{array}{c}0.996 * * * \\
(0.187)\end{array}$ \\
\hline Observations & & 6,802 & 6,80 & & 6,802 & 6,802 & 6,8 & & 6,802 \\
\hline
\end{tabular}


Notes: In this table, we present robustness for all the aspects of innovation by using Propensity Matching score techniques based on the control variables of Table 4. In Columns (1), (4), (7) we employ the nearest neighbor method, additionally in columns (2), (5), (8),) and (3), (6), (9) the kernel and at the stratification method (Zhao 2004) respectively. An asterisk indicates significance at the $10 \%$ level; two indicate significance at the $5 \%$ level; three indicate significance at the $1 \%$ level. Standard errors in parentheses $* * * \mathrm{p}<0.01, * * \mathrm{p}<0.05, * \mathrm{p}<0.1$

\subsection{Conclusions}

In this chapter, we analyze the impact of several aspects of innovation on a firm's sustainability. The results of the innovation effect on sustainability suggest that the theoretical arguments behind the positive forces of innovation are dominant in our sample. The effect of innovation quality and efficiency on sustainability is also inline and generalize these findings in our sample. This research is the first that relates all types of innovation with firms' sustainability performance and, in this sense, we provide a policy implication for the possible formulation of sustainable strategies. Our research focuses on US firms, so takes place in an economically developed economy.

Firm's sustainability is promoted not only by its innovative activity but additionally by the exposure in relative higher of lower innovation environments. Our sample includes firms from states with different innovation activities, institutional characteristics, and regulations. This characteristic differs and cannot be sufficiently captured by state-year fixed effects but have an important effect on the firm's innovation. Thus, we don't argue that these specific characteristics are less important in shaping ESG than the firm's innovation activity. Precisely the opposite; due to these characteristics business innovation activity is shaping up.

Our results indicate that the quantity and value of innovation do enhance corporate sustainable performance. We also argue that these effects become even stronger during times of recession (e.g. global financial crisis). We supplement our analysis with the use of various techniques such as the propensity matching score and instrumental variable analysis to check for robustness of our findings. The empirical results reveal that our analysis survives robustness checks.

The current framework will offer new insights and help firms to evolve and design business strategies according to the "new sustainable rules" of the modern economic environment. Indeed, the case of sustainability is already starting to transform the competitive business environment and forces companies to adapt their standards and turn regulators into allies by leading the way in 
sustainable products and services. Developing new strategies and addressing the needs of the current sustainable way requires to learn question existing knowledge mechanisms. While firms struggle to adapt, those who have already pursued sustainable innovation advance as leaders beyond the competition. 


\section{Chapter 4 - Firms' Sustainability Performance and Market Longevity: A firm-level analysis for the US}

This chapter examines the impact of environmental, social, and governance sustainability (ESG) on the United States (US) listed firms' exit decisions. Using an updated dataset consisting of a large number of US firms over the period 2007-2016, a dynamic empirical analysis to investigate the underlying relationships between ESG and firms' market exiting profile by assessing the impact of environmental, social, and governance issues is performed. Also, it provides evidence that corporate sustainability is a tool for reducing risk, enabling companies to boost their survival mechanisms and lessen their probability of failure. Finally, the empirical findings were confirmed by several robustness checks, providing useful policy implications for government officials and policymakers.

\subsection{Introduction}

The number of companies listed on the US stock market has fallen sharply in the last 20 years. In 1996, there were 8,000 listed firms in the US market, while in 2016 only 3,627 companies were listed. According to the Federal Reserve Economic Data (FRED) ${ }^{10}$, half of U.S industries have lost over $50 \%$ of their publicly traded companies during the period 1998 - 2016. These numbers highlight two issues; first, the importance of this phenomenon and, second, the growing need to study the factors that may contribute to its reduction.

The extant empirical literature has documented that a growing number of firms are exiting the US stock market, either due to failure or acquisition (Ciccotello, 2014; Grullon et. al., 2015; Jenkinson and Ljungqvist, 2001; Ritter, 2003). The transition of companies from the public to private ownership happens for many reasons, such as higher investment in R\&D, changes in ownership structure, new regulations and increased competition (Jain and Kini, 2000; Jain and Kini, 2008). Previous literature has highlighted the importance of firm-level specific characteristics such as size, market share (Geroski, 1995), and drift in profitability and growth (Fama and French, 2013);

\footnotetext{
${ }^{10}$ Federal Reserve Bank of St. Louis, 1 Federal Reserve Bank Plaza, St. Louis, MO 63102
} 
however, little is known about the impact of environmental, social, and governance (ESG) on firms' market longevity.

Firms delist due to their inability to adhere to the requirements set by markets, privatization choices to shield their strategies from public disclosure information, or because they are acquired by other companies (Doidge et al., 2017). Technological changes also impact the way the markets operate thus urging listed companies to address these challenges (Gao et al., 2013). Firms must constantly adapt to integrate new technologies and strategies that will help them to control risks and opportunities, and this has attracted the attention of many researchers (Ciccotello, 2014; Grullon et al., 2015; Rosett and Smith, 2014a, 2014b).

This paper provides several contributions to the literature. First, it contributes to the financial literature by showing that ESG influences corporate decisions and outcomes, hence playing an important role in firms' survival mechanisms. The existing literature has mainly examined the relationship between the financial performance (Clark and Viehs, 2014; Margolis et al., 2009) and value of firms that practice ESG (Cho et al., 2010; Fatemi et al., 2015; Malik, 2014; Porter, 1991; Porter and Kramer, 2011; Porter and van der Linde, 1995). These studies have linked ESG with better prospects in terms of value and performance; however, no empirical studies have examined the impact of ESG on firms' survivability. We found that publicly traded firms with ESG issues were more likely to remain listed for shorter periods of time and had a higher probability to exit the organized markets compared with sustainable firms. To the best of our knowledge, this is the first research attempt to directly link firms' ESG with their survival mechanisms and characteristics.

The rest of this paper proceeds as follows. Section 2 reviews the existing theory and presents a testable hypothesis for the empirical analysis. Section 3 discusses the sample selection and reports the descriptive statistics. Section 4 presents the analytical framework and discusses the main results. Section 5 describes the robustness analysis and testing. Section 6 summarizes the findings and provides concluding remarks. 


\subsection{Related literature and Hypotheses Development}

\subsubsection{Literature Review}

Some scholars have examined the link between sustainability and corporate value (Carroll et al., 2012; Heal, 2004, 2008; Landier and Nair, 2009); firms that incorporated strong social (Edmans, 2011) and environmental responsibility (Derwall et al., 2005) generated risk-adjusted excess returns. According to Kempf and Osthoff (2007) and Statman and Glushkov (2009), portfolios that consisted of firms with strong sustainability policies performed better than those with weak sustainability policies. Analysts based on sustainability score, over time, take more optimistic investment decisions about firms' future financial performance (Ioannou and Serafeim, 2014). Eccles, Ioannou, and Serafeim (2014) argued that there is a positive link between corporate sustainability and financial performance; thus, firms with high sustainability are more long-term oriented and issue ESG reports as a transparency and accountability business strategy. Galbreath (2013) and Margolis and Walsh (2003) stated that firms with ESG strategies are more likely to accumulate capital at a lower cost as they build stronger reputations. Consumers recognize their contribution to society and support firms with strong and social reputations (Godfrey, 2005). However, some opposing research has provided evidence that portfolios consisting of socially responsible investment (SRI) funds underperform (Hong and Kacperczyk, 2009; Renneboog et al., 2008), while Bauer et al. (2005), Hamilton et al. (1993), and Schroder (2007) concluded that had no statistically significant impact.

Previous literature (Derwall et al., 2005; Dowell et al., 2000; Edmans, 2011; Servaes and Tamayo, 2013) documented that a firm can enhance shareholder wealth by creating a positive impact on the stakeholders; firms that meet stakeholders' needs create value for shareholders (Freeman 2010). Positive sustainability performance attracts the attention of shareholders, since it has an impact on environmental (Chava, 2011; Konar and Cohen, 2001), social (Borenstein and Zimmerman 1988; Farber and Hallock 2009; Jarrell and Peltzman, 1985; King and Soule 2007; Mitchell 1989), and governance issues (Chaney and Philipich 2002; Karpoff and Lott 1993) and on firms' market value, credit risk, and cost of capital. Firms experiencing negative ESG events have a lower market value (Capelle-Blancard and Petit, 2017). Aouadi and Marsat (2016) argued that ESG controversies affect firms' market value, since they pose reputational risks; as a result, firms lose market share 
(Kang and Kim, 2013) and credibility (Godfrey et al., 2009; Yoon et al., 2006). Rennings et al. (2007) concluded that firms' reputational risks affect shareholder wealth; thus, firms try to make amends to their stakeholders after events with negative impact on their ESG. Controversial firms face a more positive stock market reaction when they start to follow ESG sustainable strategies compared with those firms that have had no ESG issues (Kotchen and Moon, 2012); therefore, ESG has a positive impact on stakeholders and adds value to firms (Donaldson and Preston 1995; Freeman 1984; Godfrey et al., 2009; Kacperczyk, 2009).

ESG reports present financial and non-financial information as a way to add value to firms and satisfy their shareholders and stakeholders (Eccles and Krzus, 2010). As a result, ESG reports that offer qualitative and quantitative information is a superior tool (Eccles and Serafeim, 2014; Higgins et al., 2014) for firms to influence stakeholders and enhance transparency and corporate value (Ioannou and Serafeim, 2019). Stakeholders (consumers, employees, and investors) prefer transparent firms; consequently, firms that incorporate sustainability into their business strategies establish strong brand names, reputations, and credibility (Brown and Dacin 1997; Cornell and Shapiro 1987; Hammond and Slocum, 1996) that create positive economic value (McWilliams and Siegel, 2001) and enhance stakeholders' commitment (Godfrey 2005; Wang et al., 2008). Firms' sustainable performance can also enhance their reputation as employers and attract highly qualified personnel (Greening and Turban, 2000; Turban and Greening, 1996), with positive outcomes for corporate financial performance (Edmans, 2011); as a result, firms with positive employee relations have lower costs for debt financing and higher credit ratings (Bauer et al., 2009).

Sustainability can be used as a risk mitigation tool (Kim et al., 2014) that decreases systematic risk and increases firms' value (Albuquerque et al., 2019), in particular, by increasing growth opportunities and minimizing risk exposure; the higher the aggregated ESG performance, the lower the financial risk (Orlitzky and Benjamin, 2001). Sharpe (1964) stated that firms' total risks (idiosyncratic risks and systematic risks) reflect their stock volatility (Jo and Na, 2012; Luo and Bhattacharya, 2009). McWilliams and Siegel (2001) and Oikonomou et al. (2012) stated that sustainability enhances firms' value, based on a risk-return balance (Derwall, 2007), by lowering costs and idiosyncratic risks, and that ESG concerns are associated with higher systematic risk. In addition, high ESG performance can reduce the negative outcomes of corporate scandals (Vanhamme and Grobben, 2009). 
Furthermore, ESG can be used to avoid costly fines, since strong sustainability business strategies involve less likelihood of lawsuits and fines (McGuire et al., 1988). Bhat (1998) argued that fines can have a major impact on firms' performance and profits; hence, firms adopt sustainable business strategies to avoid fines and adhere to regulations. In this way, they create value for their stakeholders and contribute to a sustainable society. Francis and Armstrong (2003) suggested that a good ethical image, resting on sustainable business strategies, can boost firms' reputations, help them to abide by regulations, and reduce the possibility of penalties; as a result, companies will have higher returns and improved access to capital (Cheng, Ioannou and Serafeim, 2014) and other necessary resources (Rindova and Fombrun, 1999), leading to consumers preferring them over firms which are less responsible. Firms that fail to integrate ESG exhibit poor performance, since they lack access to private equity and have high capital costs (Crifo and Forget, 2013).

Deng et al. (2013) concluded that corporate sustainable performance creates value for shareholders through merger and acquisition strategies. Flammer (2015) also reported that sustainability enhances shareholder value; firms use sustainability to create strategies with superior characteristics that generate competitive advantage and increase shareholder value (Dimson et al., 2015). Also, sustainability improves financial returns for shareholders (Alexander and Buchholz, 1978; McWilliams et al., 2006; Porter and Kramer, 2006; Porter and van der Linde, 1995), resulting in firms' higher market values; investors react strongly to sustainability reports that contain economic and legal information, while reacting milder to those that contain social and environmental information. Kruger (2015) stated that stock prices decrease when information reveals firms' ESG issues, creating a negative impact on stakeholders. Capelle-Blancard and Petit (2017) argued that ESG reports mitigate the risk of lower market value when information is disclosed by the media, rather than by the firm; however, the loss is greater, and has an impact on stock prices, when reports contain quantitative economic or legal data.

Mervelskemper and Streit (2016) concluded that stock markets value firms' ESG performance. Aouadi and Marsat (2016) believed that firms with ESG strategy enhance their financial performance. Waddock and Graves (1997) asserted that an ESG strategy can be regarded as a form of quality management, since it includes long-term external factors, creating a competitive advantage. Firms' sustainability performance ensures lower financial and stock market risk and, consequently, a lower probability of a firm's crisis (Oikonomou et al., 2012); thus, firms integrate 
sustainability into their business strategies to gain competitive advantage, claim greater market share, reduce information asymmetry, and mitigate risks (Du et al., 2011).

\subsubsection{Hypothesis Development}

Based on the above information, we concluded that, in terms of risk, how companies make money is more important than how much money they make. Investment in ESG involves a range of positive potential impacts, reduces risk factors, and helps firms to meet regulations and thereby avoid the need for enforcement. We expected that, through ESG performance, firms would reduce information asymmetry, capitalize on valuation benefits, and secure their market position and consumer loyalty. Additionally, the literature documented that ESG has a strongly positive effect on the value of firms. We, therefore, hypothesized that:

Hypothesis 1. ESG is a tool for companies to control reputational risks, increase their competitiveness, reduce uncertainty, and formulate strategies concerning non-financial factors (such as environmental, social, and governance factors), but with an increasing impact on financial performance, that enables them to survive for longer periods in the market. Given all the above, we expected firms with ESG reputational risk exposure to be more vulnerable, incorporate higher risk, and face a higher probability of delisting.

\subsection{Data and sample variables}

\subsubsection{Sample Construction}

For our empirical analysis, we constructed a sample based on annual financial and stock price data for US publicly listed firms, produced by the Center for Research in Security Prices (CRSP) and Compustat respectively, while information for patents and trademarks comes from the Orbis Intellectual Property -a global company database, produced by the Bureau Van Dijk (2005). We gathered sustainability information from the RepRisk database. The former data started in 2007 and our final dataset consisted of 1,585 US publicly listed companies during the period 2007-2016. 


\subsubsection{Data Description}

The variable of interest was a firm's ESG based on the RepRisk Index (RRI), which is a risk metric that quantifies a company's exposure to environmental, social, and governance issues. The RRI score is calculated according to several factors, including the credibility of the information source, the frequency and timing of criticisms, the novelty and severity of the criticism, and the company's exposure to reputational risks relating to ESG. The RRI score ranges from zero to a hundred, with a high score corresponding to high-risk exposure. We considered ESG issues as a dummy variable that took the value of one when the RRI score was greater than zero. We retrieved information for a firm's sales (Log (Sales), advertising (Advertising), and return on equity (Return on Equity), in millions of dollars, from the Compustat database. To control for a firm's innovation and market establishment, we used the natural logarithm of a firm's patents $(\log ($ Patents +1$))$ and trademarks $(\log (T M+1))$. Data for both of the former measures, as well as for firm age $(\log ($ Firm Age $))$, came from Orbis Intellectual Property: a global company database produced by Bureau van Dijk (2005). Information about firms' duration on the market, as well as delisting codes, came from the CRSP database and, for merger and acquisition announcement days, from the Securities Data Corporation's (SDC) database. We retrieved delisting codes from the CRSP to indicate the status of the issuing firm. Issue codes equal to 100 indicated that firms at the end of our sampling period were still trading, while those with delisting codes from 200 to 299 had been acquired, and those with codes above 300 were delisted for negative reasons (Alhadab et al., 2014, Espenlaub et al., 2012). Last but not least, to control for the global financial crisis (Crisis), we used a dummy that took the value of 1 for the US crisis period beginning in 2008, and zero otherwise. Table 8 provides summary statistics of our variables over the sample period, 2007-2016. 
Table 8. Summary Statistics

Panel A: Descriptive statistics for firms 2007-2016

\begin{tabular}{|c|c|c|c|c|c|}
\hline Variable & Obs & Mean & Std. Dev. & Min & $\operatorname{Max}$ \\
\hline ESG Issues & 11,337 & .448 & .497 & 0 & 1 \\
\hline$R R I$ & 11,337 & 7.40 & 10.83 & 0 & 71.50 \\
\hline Log (Sales) & 11,337 & 7.35 & 1.88 & .005 & 13.08 \\
\hline$(\log (\text { Sales }))^{2}$ & 11,337 & 57.69 & 26.87 & .000 & 171.31 \\
\hline Log (Sales growth) & 11,337 & .251 & 4.96 & -.998 & 474.81 \\
\hline Log (Advertising) & 11,337 & 1.61 & 2.19 & 0 & 9.182 \\
\hline $\log ($ FirmAge $)$ & 11,337 & 3.29 & .774 & 0 & 5.043 \\
\hline Log (Patents +1$)$ & 11,337 & 1.01 & 1.73 & 1.01 & 9.10 \\
\hline $\log (T M+1)$ & 11,337 & .228 & 0.541 & 0 & 4.574 \\
\hline Return on Equity & 11,337 & .037 & 1.61 & -58.54 & 99.50 \\
\hline
\end{tabular}

\begin{tabular}{lcccc}
\hline Panel B: Failed and survived statistics & & \\
\hline & From 2007 to November 2016- & total failure & From 2007 to November 2016-failed due to negative \\
\cline { 2 - 5 } & $N$ & $\%$ & $N$ & $7.1 \%$ \\
\hline Failed & 540 & $34 \%$ & 1,472 & $92.9 \%$ \\
Survived & 1,045 & $66 \%$ & 1,585 & $100 \%$ \\
Total & 1,585 & 100.00 & $\%$ & $\%$ \\
\hline
\end{tabular}

Notes: Panel A reports descriptive statistics for a sample of 1,585 US publicly listed companies. It documents the mean, standard deviation, minimum, and maximum values for the sample, as well as the total number of observations. Panel B presents the distribution of the overall sample for both groups of firms: survived and failed. Survived firms are those that were still trading (CRSP delisting code of 100); failed firms are those that were delisted due to acquisitions (delisting code from 200 to 299) or for negative reasons (delisting codes greater than or equal to 300). $N$ denotes the number of observations.

Firms' RRI in was, on average, quite low at about 7.40 (out of 100) and, on average, firms Log (Sales growth) was .25\%. Also, the average log of age was 3.29. Firms had, on average, $7.35 \%$ of $\log$ (Sales), and their share of $\log ($ Patents +1$)$ was $1.01 \%$, while their $\log (T M+1)$ share was .228. Last but not least, the shares of return on equity and advertising were $037 \%$ and $1.61 \%$, respectively. Panel B reports the number and shares of delisted firms in our sample. On average, $66 \%$ of firms survived, while $34 \%$ of firms were delisted due to acquisitions (delisting codes from 200 to 299) or for negative reasons (delisting codes greater than or equal to 300). If we excluded delisting due to a successful merger then, on average, we had $92.9 \%$ surviving firms and $7.1 \%$ that failed due to negative reasons. 


\subsubsection{Graphical Representation of State average ESG issues and delisting activity for US firms}

Figure 9 provides a visualization of the spatial distribution of the ESG RRI across US states over the period 2007-2016. Since we had data regarding the locations of the firms and their sustainability performance, we were able to provide a spatial presentation of the firms in our sample. Figure 10 presents firms' market exiting distribution across states, with states with the highest numbers of delisting firms shown in deep red and those states with, on average, lower concentrations of sustainable firms shown in orange and yellow. Comparing these two figures, it was clear that states with greater ESG issues had more intense delisting activity.

Figure 8. State average ESG issues for US firms over the period 2007 and 2016.

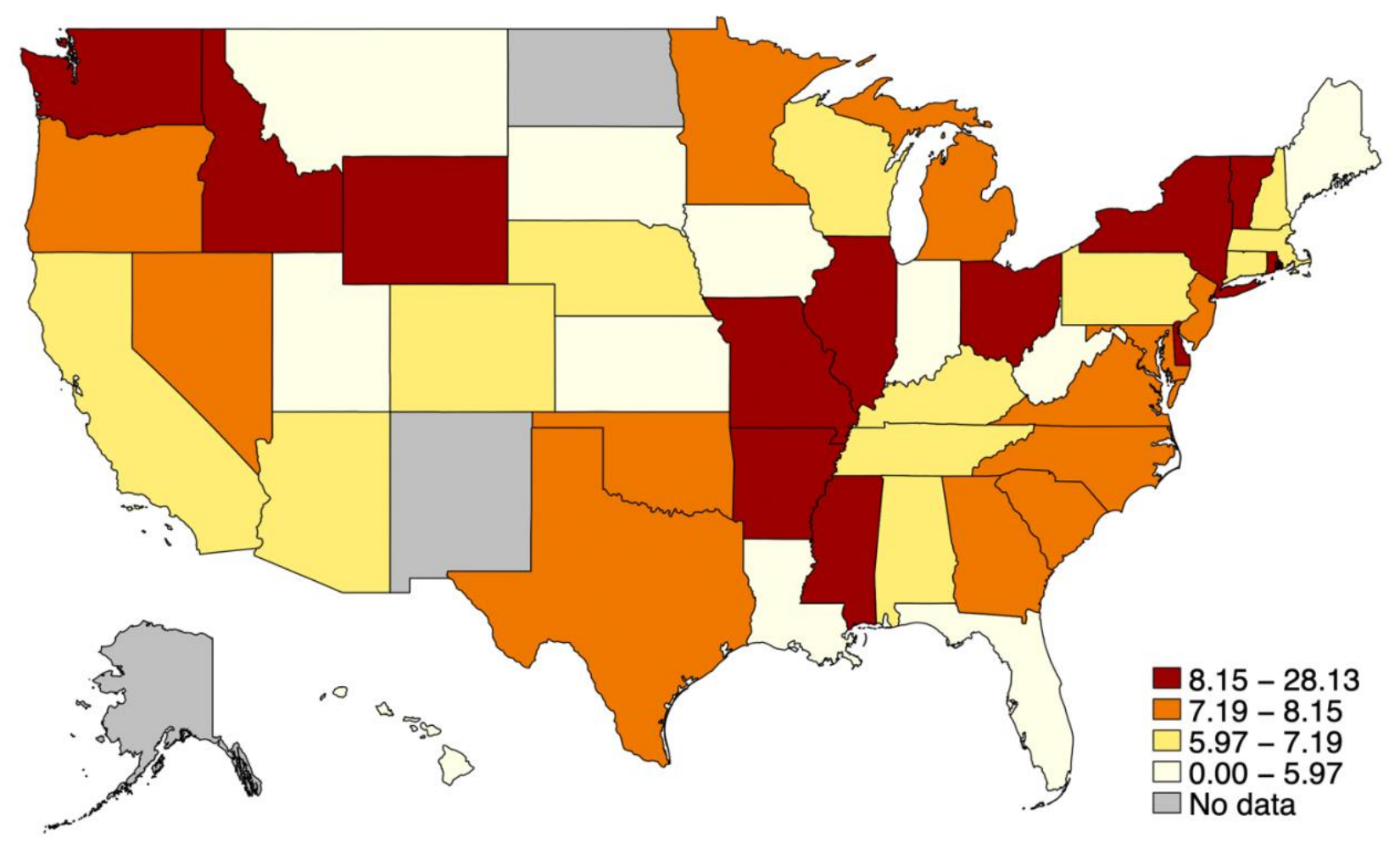


Figure 9. State average delisting activity for US firms over the period 2007 and 2016.

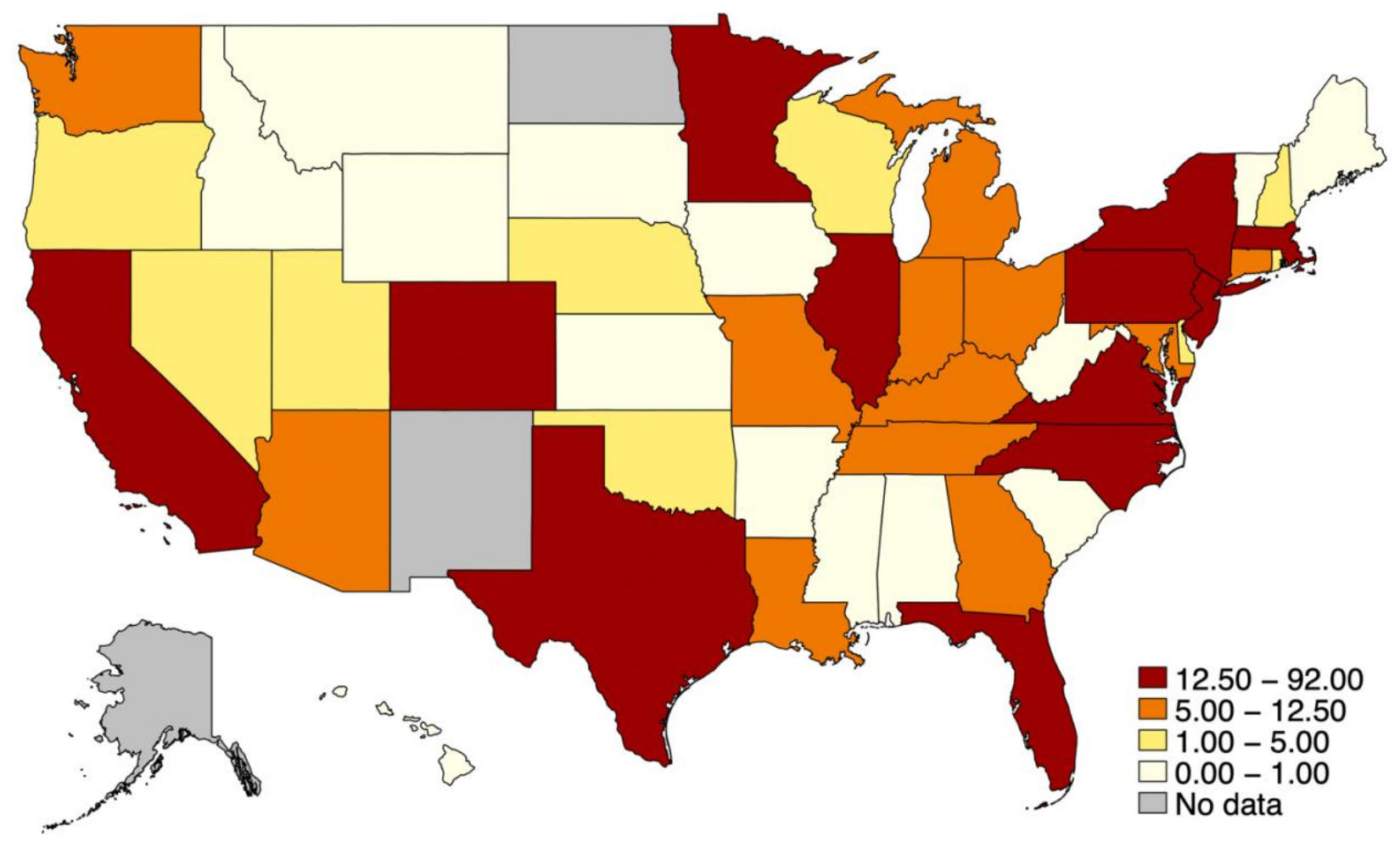

\subsection{Estimation strategy and methodology}

Survival analysis is a branch of statistics that analyzes and determines the expected length of time until an event happens. Extensive literature has examined firms' market survivability using this statistical tool (e.g., Alhadab et al., 2015; Carpentier and Suret, 2011; Espenlaub et al., 2012; Fama and French, 2004; Gerakos et al., 2013; Hensler et al., 1997; Jain and Kini, 2000; Jain and Martin, 2005). One reason for using this method is its advantage over regression methods (such as probit and logit models) to account for both event occurrence and time to the event. Moreover, this kind of technique works well for censored data and events with different time horizons (LeClere, 2000; Shumway, 2001). In our analysis, to study the association between ESG performance and firms' market survival, we applied nonparametric, semiparametric, and parametric approaches. By using nonparametric estimates of hazard and survival functions, we compared the failure risks and survival rates of firms with ESG issues and those without, to determine whether ESG had an impact on firms' survival. The hazard function expressed a conditional probability of failure, taking into 
account the time that the firm existed in the market. We used the Nelson-Aalen estimator to compute the hazard functions for the two groups:

$$
\widehat{H}(t)=\sum_{t_{i} \leq t} \frac{d_{i}}{n_{i}}
$$

We defined $\mathrm{d}_{\mathrm{i}}$ as the number of failed firms at time $\mathrm{t}_{\mathrm{i}}$, and $\mathrm{n}_{\mathrm{i}}$ is the number of firms with possible risk at time ti, then we computed with the survival function the probability of firms' survival at a particular time. We expected the survival function curve for firms with high ESG performance to be above those with low ESG performance. We used the Kaplan-Meier methodology to estimate the survival functions:

$$
\hat{S}(t)=\prod_{t_{i} \leq t} \frac{n_{i}-d_{i}}{n_{i}}
$$

Finally, we used a log-rank test to examine the difference in survival curves between firms with high ESG intensity and those with low ESG intensity. We used a semi-parametric approach to determine fit, via maximum likelihood proportional hazards for a panel with multiple records, using the Cox proportional hazards model (Cox, 1972), which extended our analysis by taking into account the simultaneous impact of several risk factors on survival time. One of the advantages of the Cox proportional hazards model is that it works with no pre-specified baseline hazard function and can thus take any functional form (Allison, 2000). We estimated the following model by applying a Cox proportional hazard model to the panel data:

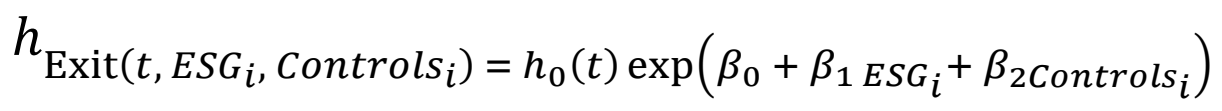

We defined $h(t)$ as the baseline hazard function with $t$ as the time to exit from the market (failure). The dependent variable captured the risk of exiting the market. The hazard ratios measured the increase in failure risk for a unit increase of the independent variables. For the continuous variables, the hazard rate for a one-unit increase was 100*(hazard ratio - 1) (Allison, 2000). Our variable of interest was the firms' ESG issues. Following the literature (Hensler et al., 1997; Wagner, 2010), 
we controlled for firms' characteristics, such as sales, sales growth, advertising, firm's age, patents, trademarks, return on equity, and the financial crisis. All the regressions included year and industry fixed effects.

Finally, we assumed that our data followed the Weibull distribution and fitted a parametric survival model with panel data. We clustered panel surviving data (Gutierrez et al., 2001) and fitted a mixed effect $^{11}$ survival model containing both fixed and random effects. With the inclusion of random effects, we took into account potential bias that could arise from intra-cluster correlations. The definitions of all the variables are provided in Appendix B.

\subsection{Results and discussion}

\subsubsection{Analysis of the Hazard and Survival Curves (non-parametric approach)}

We provide below a visual representation of the hazard and survival functions for firms with ESG issues and those without. Figures 11 and 12 show the Kaplan-Meier survival and Nelson-Aalen cumulative hazard estimates. Hazard functions for firms with no ESG issues (Figure 11) were lower than those for firms with ESG issues, and the gap widened over the length of time. By contrast, as shown in Figure 12, the survival function of firms with ESG issues was lower than that of firms with no ESG issues. The graphical analysis indicated that the probability of delisting was greater for firms with ESG issues throughout the entire period of our research. Additionally, the long-run test showed that the survival distributions of the two samples differed at a $1 \%$ level of significance and provided evidence that the comparison was efficient. In summary, the hazard and survival functions demonstrated that firms with ESG issues were more likely to exit the market than those with no ESG issues. The results suggested that sustainability is a risk mitigation tool and that sustainable companies tend to be less risky, with better survival profiles.

\footnotetext{
11 Mixed-effects survival models contain both fixed effects and random effects. In longitudinal and panel data, random effects are useful for modeling intracluster correlations: that is, observations in the same cluster that are correlated because they share common cluster-level random effects.
} 
Figure 10. Survival Estimates firms with and without ESG issues

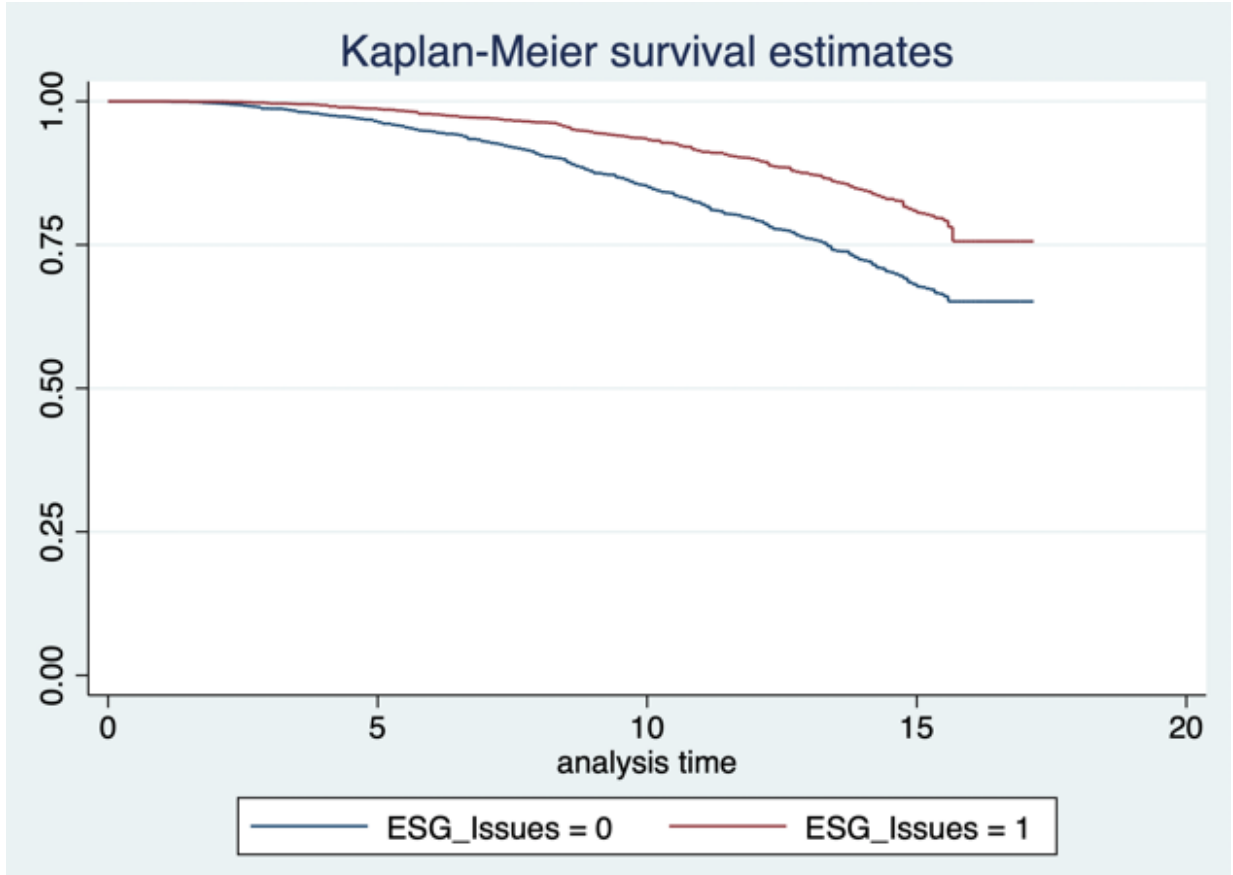

Figure 11. Survival function firms with and without ESG issues.

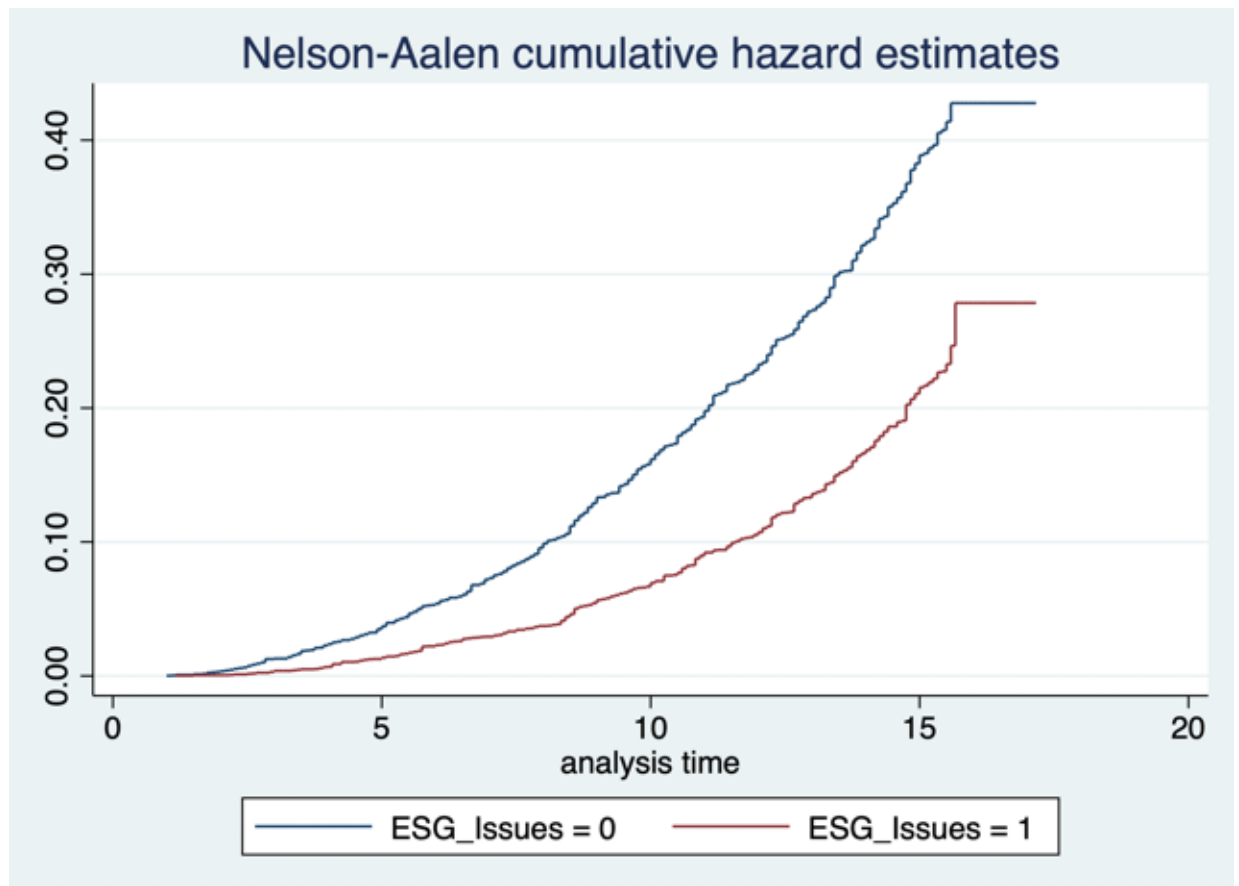




\subsubsection{Estimation using a semi-parametric and parametric approach}

To test our hypothesis, we used two model specifications. Table 9 documents the results of the Cox proportional hazards model (specification 1), which used a semi-parametric approach (columns 1 and 3). To further ensure the robustness of the results (specification 2), we estimated a mixedeffects parametric survival-time model, assuming that the conditional distribution of the response was the Weibull distribution (columns 2 and 4). For both specifications, the results were consistent and in line with the findings of the previous non-parametric analysis. In columns 1 and 2, we account for all firms that and exited the market, while in columns 3 and 4 , we expanded our analysis by taking into account firms that exited the market for negative reasons. We controlled for the presence of no linear effects by using the quadratic term of sales $(\log (\text { Sales }))^{2}$ and expected to find a negative association with firms' probability of exiting the market. We controlled for growth in sales (Sales growth) (Hirsch, 1990) and innovation activity, proxied by patents and trademarks. We found a negative association between patents and market delisting, which was expected since firms, through patenting, protect themselves in the market, reduce risks, and acquire a competitive advantage. Last but not least, we controlled for firms' advertising expenses to capture adjustments in consumers' preferences and, hence, public support for companies. The results indicated that for both of the specifications we used to define exit from the market, and both the semi-parametric and parametric models, firms with ESG issues faced a higher probability of delisting, of $8 \%$ to $17.8 \%$, compared with firms without ESG issues. Our estimates provided evidence to support our hypothesis that ESG issues weakened companies, causing increased uncertainty and decreased competitiveness. In summary, through ESG, firms formulated strategies regarding non-financial factors (such as environmental, social, and governance factors), but with a great financial impact that enabled them to survive for longer periods in the market. 
Table 9. Semi- parametric and parametric estimates of firms' ESG impact on the probability exiting the market

(1) (2) (3)

VARIABLES

\begin{tabular}{|c|c|c|c|c|}
\hline & \multicolumn{2}{|c|}{ All firms exiting the market } & \multicolumn{2}{|c|}{$\begin{array}{c}\text { Firms exiting the market for } \\
\text { negative reasons }\end{array}$} \\
\hline & semi-parametric & parametric & semi-parametric & parametric \\
\hline \multirow[t]{2}{*}{ ESG Issues } & $0.080^{*}$ & $0.077^{*}$ & $0.178^{* *}$ & $0.178^{* *}$ \\
\hline & $(0.041)$ & $(0.041)$ & $(0.070)$ & $(0.070)$ \\
\hline \multirow[t]{2}{*}{ Log (Sales) } & $0.090^{* *}$ & $0.086^{* *}$ & -0.004 & -0.004 \\
\hline & $(0.038)$ & $(0.037)$ & $(0.039)$ & $(0.039)$ \\
\hline \multirow[t]{2}{*}{$(\log (\text { Sales }))^{2}$} & $-0.028 * * *$ & $-0.027 * * *$ & $-0.022 * * *$ & $-0.022 * * *$ \\
\hline & $(0.003)$ & $(0.003)$ & $(0.004)$ & $(0.004)$ \\
\hline \multirow[t]{2}{*}{ Log (Sales growth) } & $0.003 * * *$ & $0.003 * * *$ & $0.006 * * *$ & $0.006^{* * * *}$ \\
\hline & $(0.001)$ & $(0.001)$ & $(0.001)$ & $(0.001)$ \\
\hline \multirow[t]{2}{*}{$\log ($ FirmAge $)$} & $-0.205^{* * * *}$ & $-0.195 * * *$ & $-0.193 * * *$ & $-0.192 * * *$ \\
\hline & $(0.024)$ & $(0.024)$ & $(0.038)$ & $(0.038)$ \\
\hline \multirow[t]{2}{*}{ Log (Patents +1$)$} & $-0.076^{* * *}$ & $-0.077 * * *$ & $-0.113 * * *$ & $-0.112 * * *$ \\
\hline & $(0.014)$ & $(0.014)$ & $(0.030)$ & $(0.030)$ \\
\hline \multirow[t]{2}{*}{$\log (T M+1)$} & -0.026 & -0.029 & $-0.166 * * *$ & $-0.169 * * *$ \\
\hline & $(0.032)$ & $(0.032)$ & $(0.062)$ & $(0.062)$ \\
\hline \multirow[t]{2}{*}{ Log (Advertising) } & -0.002 & -0.002 & 0.017 & 0.017 \\
\hline & $(0.011)$ & $(0.010)$ & $(0.019)$ & $(0.019)$ \\
\hline \multirow[t]{2}{*}{ Crisis } & & $0.988 * * *$ & $0.958 * * *$ & $0.960 * * *$ \\
\hline & & $(0.152)$ & $(0.276)$ & $(0.275)$ \\
\hline \multirow[t]{2}{*}{ Return on Equity } & $-0.035 * * *$ & $-0.033 * *$ & $-0.055^{* * *}$ & $-0.056 * * *$ \\
\hline & $(0.014)$ & $(0.014)$ & $(0.010)$ & $(0.010)$ \\
\hline Chi-square test probability & 0.000 & 0.000 & 0.000 & 0.000 \\
\hline Observations & 11,337 & 11,337 & 11,337 & 11,337 \\
\hline Year FE & YES & YES & YES & YES \\
\hline Industry FE & YES & YES & YES & YES \\
\hline
\end{tabular}

Notes: This table provides the Cox estimations of proportional hazards and the mixed-effects survival models for the probability of failure and time-to-failure. In all the regressions, we included industry and year fixed effects. All the variables are defined in the Appendix. The standard errors are shown in parentheses below the estimated coefficients. Robust standard errors are in parentheses. One, two, and three asterisks indicate statistical significance at the 10\%, 5\%, and $1 \%$ levels, respectively. $* * * \mathrm{p}<0.01, * * \mathrm{p}<0.05, * \mathrm{p}<0.1$. 


\subsection{Robustness checks}

We used semi-parametric and parametric approaches to estimate the impact of three major ESG issue components (environmental [EP] issues, social [SP] issues, and governance [GP] issues) on the probability of a firm exiting the market. In Table 10, columns 1, 3, 5, and 7, and columns 2, 4, 6 , and 8 , present the semi-parametric and parametric estimates, respectively. Concerning delisting scenarios, we defined as failed all the firms exiting the market for negative reasons. In this way, we categorized firms according to their inability to control risk and revealed their weaknesses in complying with the prerequisite market criteria. Following the literature, we controlled for sales (InSales) and we captured the presence of no linear effects by using the quadratic term of sales ( $\log (\text { Sales })^{2}$ expecting to find a negative association with firms' probability of exiting the market. We also controlled for growth in sales (Sales growth) (Hirsch, 1990) and innovation activity, proxied by patents and trademarks. We found a negative association between innovation expressed by patents and trademarks and market delisting, which was expected because firms, through innovation, protect themselves in the market, reduce risks, and acquire a competitive advantage. Last but not least, we controlled for firms' advertising expenses to capture adjustments in consumers' preferences and, hence, public support for companies. Our results indicated that firms' ESG exposure to reputational risks significantly increased the probability of them delisting and reduced the time that firms remained listed. Our findings were extended in respect of two of the main components of ESG issues (SP and GP), but not EP. Concerning this outcome, our analysis showed that firms with social and governance issues had a greater degree of information asymmetry lower transparency and social reputation, so they were more likely to exit. 
Table 10. Semi- parametric and parametric estimates of three major sustainability (ESG) components namely environmental (EP), social (SP) and governance (GP) impact on the probability exiting the market

\begin{tabular}{|c|c|c|c|c|c|c|c|c|}
\hline & (1) & (2) & (3) & (4) & (5) & (6) & (7) & $\overline{(8)}$ \\
\hline \multirow[t]{3}{*}{ VARIABLES } & ESG & ESG & EP & EP & GP & GP & SP & SP \\
\hline & Issues & Issues & Issues & Issues & Issues & Issues & Issues & Issues \\
\hline & $\begin{array}{c}\text { semi- } \\
\text { parametric }\end{array}$ & parametric & $\begin{array}{c}\text { semi- } \\
\text { parametric }\end{array}$ & parametric & $\begin{array}{c}\text { semi- } \\
\text { parametric }\end{array}$ & parametric & $\begin{array}{c}\text { semi- } \\
\text { parametric }\end{array}$ & parametric \\
\hline \multirow[t]{2}{*}{ ESG Issues } & $0.178^{* *}$ & $0.178^{* *}$ & & & & & & \\
\hline & $(0.070)$ & $(0.070)$ & & & & & & \\
\hline \multirow[t]{2}{*}{ Environmental Issues } & & & 0.136 & 0.137 & & & & \\
\hline & & & $(0.087)$ & $(0.087)$ & & & & \\
\hline \multirow[t]{2}{*}{ Governance Issues } & & & & & $0.258 * * *$ & $0.255^{* * *}$ & & \\
\hline & & & & & $(0.081)$ & $(0.081)$ & & \\
\hline Social Issues & & & & & & & $0.165^{* *}$ & $0.166 * *$ \\
\hline \multirow[t]{2}{*}{$\log ($ Sales $)$} & -0.004 & -0.004 & -0.005 & -0.006 & -0.001 & -0.002 & -0.004 & -0.005 \\
\hline & $(0.039)$ & $(0.039)$ & $(0.039)$ & $(0.039)$ & $(0.040)$ & $(0.040)$ & $(0.040)$ & $(0.040)$ \\
\hline \multirow[t]{2}{*}{$(\log (\text { Sales }))^{2}$} & $-0.022 * * *$ & $-0.022 * * *$ & $-0.021 * * *$ & $-0.021 * * *$ & $-0.022 * * *$ & $-0.022 * * *$ & $-0.022 * * *$ & $-0.022 * * *$ \\
\hline & $(0.004)$ & $(0.004)$ & $(0.004)$ & $(0.004)$ & $(0.004)$ & $(0.004)$ & $(0.004)$ & $(0.004)$ \\
\hline \multirow[t]{2}{*}{ Log (Sales growth) } & $0.006^{* * *}$ & $0.006^{* * *}$ & $0.006 * * *$ & $0.006 * * *$ & $0.006^{* * *}$ & $0.006 * * *$ & $0.006 * * *$ & $0.006 * * *$ \\
\hline & $(0.001)$ & $(0.001)$ & $(0.001)$ & $(0.001)$ & $(0.001)$ & $(0.001)$ & $(0.001)$ & $(0.001)$ \\
\hline \multirow[t]{2}{*}{$\log ($ FirmAge $)$} & $-0.193 * * *$ & $-0.192 * * *$ & $-0.194 * * *$ & $-0.194 * * *$ & $-0.192 * * *$ & $-0.191 * * *$ & $-0.194 * * *$ & $-0.193 * * *$ \\
\hline & $(0.038)$ & $(0.038)$ & $(0.038)$ & $(0.038)$ & $(0.039)$ & $(0.039)$ & $(0.038)$ & $(0.038)$ \\
\hline \multirow[t]{2}{*}{$\log ($ Patents +1$)$} & $-0.113 * * *$ & $-0.112 * * *$ & $-0.113 * * *$ & $-0.112 * * *$ & $-0.119 * * *$ & $-0.117 * * *$ & $-0.113 * * *$ & $-0.111 * * *$ \\
\hline & $(0.030)$ & $(0.030)$ & $(0.030)$ & $(0.030)$ & $(0.029)$ & $(0.030)$ & $(0.029)$ & $(0.030)$ \\
\hline \multirow[t]{2}{*}{$\log (T M+1)$} & $-0.166 * * *$ & $-0.169 * * *$ & $-0.163 * * *$ & $-0.166^{* * *}$ & $-0.162 * * *$ & $-0.165 * * *$ & $-0.165^{* * *}$ & $-0.168 * * *$ \\
\hline & $(0.062)$ & $(0.062)$ & $(0.062)$ & $(0.062)$ & $(0.062)$ & $(0.062)$ & $(0.062)$ & $(0.062)$ \\
\hline \multirow[t]{2}{*}{ Log (Advertising) } & 0.017 & 0.017 & 0.019 & 0.019 & 0.015 & 0.015 & 0.018 & 0.018 \\
\hline & $(0.019)$ & $(0.019)$ & $(0.019)$ & (0.019) & (0.019) & $(0.019)$ & $(0.019)$ & $(0.019)$ \\
\hline \multirow[t]{2}{*}{ Crisis } & $0.958 * * *$ & $0.960 * * *$ & $0.869 * * *$ & $0.871 * * *$ & $0.940 * * *$ & $0.941 * * *$ & $0.913 * * *$ & $0.915^{* * *}$ \\
\hline & $(0.276)$ & $(0.275)$ & $(0.273)$ & $(0.273)$ & $(0.274)$ & $(0.273)$ & $(0.275)$ & $(0.274)$ \\
\hline \multirow[t]{2}{*}{ Return on Equity } & $-0.055^{* * *}$ & $-0.056^{* * *}$ & $-0.055^{* * *}$ & $-0.056^{* * *}$ & $-0.055^{* * *}$ & $-0.055^{* * *}$ & $-0.055^{* * *}$ & $-0.055^{* * *}$ \\
\hline & $(0.010)$ & $(0.010)$ & $(0.010)$ & $(0.010)$ & $(0.010)$ & $(0.010)$ & $(0.010)$ & $(0.010)$ \\
\hline Chi-square test probability & 0.000 & 0.000 & 0.000 & 0.000 & 0.000 & 0.000 & 0.000 & 0.000 \\
\hline Observations & 11,337 & 11,337 & 11,337 & 11,337 & 11,337 & 11,337 & 11,337 & 11,337 \\
\hline
\end{tabular}




$\begin{array}{lcccccccc}\text { Year FE } & \text { YES } & \text { YES } & \text { YES } & \text { YES } & \text { YES } & \text { YES } & \text { YES } & \text { YES } \\ \text { Industry FE } & \text { YES } & \text { YES } & \text { YES } & \text { YES } & \text { YES } & \text { YES } & \text { YES } & \text { YES }\end{array}$

Notes: This table provides the Cox estimations of the proportional hazards and mixed-effects survival models for the probability of failure and time-to-failure for the three major ESG issue components. In all the regressions, we included industry and year fixed effects. All the variables are defined in the Appendix. The standard errors are shown in parentheses below the estimated coefficients. Robust standard errors are in parentheses. One, two, and three asterisks indicate statistical significance at the $10 \%, 5 \%$, and $1 \%$ levels, respectively. $* * * \mathrm{p}<0.01, * * \mathrm{p}<0.05, * \mathrm{p}<0.1$.

\subsubsection{Controlling for Service - Manufacturing Industries and crisis periods}

Service and manufacturing industries may comprise firms with different characteristics, in terms of growth, innovation, and risk exposure. We, therefore, studied the impact of ESG issues on firms' probability of exiting the market concerning these two industries. We expected in the manufacturing industry transparency and lower information asymmetries, while in the service industry more intangibility (Castaldi 2018; Castaldi and Giarratana, 2018). We also included the three major components of ESG issues (EP issues, SP issues, and GP issues). Our analysis considered failed firms and all those exiting the market, but excluded firms that successfully exited from the market through a merger and acquisition (M\&A). We defined as a successful exit one for which the share price of the company increased after the merger and acquisition announcement. We performed a semi-parametric analysis using the Cox proportional hazards model. We controlled for the presence of no linear effects by using the quadratic term of sales $(\log (\text { Sales }))^{2}$ and expected to find a negative association with firms' probability of exiting the market. We controlled for growth in sales (Sales growth) (Hirsch, 1990) and innovation activity, proxied by patents and trademarks. We found a negative association between patents, trademarks, and market delisting (Table 11). This was expected, because firms' patent and trademark investing protected them in the market, increased market establishment and consumer loyalty, reduced risks, and enabled them to acquire a competitive advantage. We controlled for firms' advertising expenses to capture adjustments in consumers' preferences and, hence, public support for companies. By using semi-parametric estimates, we extended our initial findings to the industry level. We found that only the firms in the manufacturing sector were vulnerable to ESG reputation risks, while those in the services sector were not. When we focused on the ESG issue components, the results were in 
line with the former of ESG issues, indicating a higher probability of delisting, from $20 \%$ to $38.6 \%$, in the manufacturing sector for governance and social reputation exposure. This was consistent with the view that weak firms in product markets have a greater likelihood of delisting (Chemmanur et al., 2019). Overall, our results showed that governance and social issues in the manufacturing industry play an important role in firms' delisting. 
Table 11. Semi- parametric estimates of ESG impact on firm exiting the market Controlling for Service - Manufacturing Industries

\begin{tabular}{|c|c|c|c|c|c|c|c|c|c|c|c|c|}
\hline & (1) & (2) & (3) & (4) & (5) & (6) & (7) & (8) & (9) & (10) & (11) & (12) \\
\hline \multirow[t]{5}{*}{ VARIABLES } & $-\mathrm{t}$ & $-\mathrm{t}$ & $-\mathrm{t}$ & $-\mathrm{t}$ & $-\mathrm{t}$ & $-\mathrm{t}$ & $-\mathrm{t}$ & $-\mathrm{t}$ & $-\mathrm{t}$ & $-\mathrm{t}$ & $-\mathrm{t}$ & $-\mathrm{t}$ \\
\hline & Total & Service & Manufacturing & Total & Service & Manufacturing & Total & Service & Manufacturing & Total & Service & Manufacturing \\
\hline & Sectors & & & Sectors & & & Sectors & & & Sectors & & \\
\hline & ESG & ESG & ESG Issues & EP Issues & EP Issues & EP Issues & GP Issues & GP Issues & GP Issues & SP Issues & SP Issues & SP Issues \\
\hline & Issues & Issues & & & & & & & & & & \\
\hline \multirow[t]{2}{*}{ ESG Issues } & $0.178 * *$ & 0.124 & $0.200^{* *}$ & & & & & & & & & \\
\hline & $(0.070)$ & (0.108) & (0.092) & & & & & & & & & \\
\hline \multirow{3}{*}{$\begin{array}{l}\text { Environmental } \\
\text { Issues }\end{array}$} & & & & 0.136 & 0.112 & 0.137 & & & & & & \\
\hline & & & & & & & & & & & & \\
\hline & & & & $(0.087)$ & $(0.153)$ & $(0.106)$ & & & & & & \\
\hline \multirow{3}{*}{$\begin{array}{l}\text { Governance } \\
\text { Issues }\end{array}$} & & & & & & & $0.258 * * *$ & 0.039 & $0.386 * * *$ & & & \\
\hline & & & & & & & & & & & & \\
\hline & & & & & & & $(0.081)$ & $(0.127)$ & $(0.106)$ & & & \\
\hline \multirow[t]{2}{*}{ Social Issues } & & & & & & & & & & $0.165^{* *}$ & -0.088 & $0.274 * * *$ \\
\hline & & & & & & & & & & $(0.078)$ & $(0.132)$ & $(0.100)$ \\
\hline \multirow[t]{2}{*}{ Log (Sales) } & -0.004 & -0.059 & 0.005 & -0.005 & -0.056 & 0.003 & -0.001 & -0.063 & 0.012 & -0.004 & -0.072 & 0.009 \\
\hline & $(0.039)$ & $(0.091)$ & $(0.046)$ & $(0.039)$ & $(0.091)$ & $(0.045)$ & $(0.040)$ & $(0.090)$ & $(0.046)$ & $(0.040)$ & $(0.091)$ & $(0.046)$ \\
\hline \multirow[t]{2}{*}{$(\log (\text { Sales }))^{2}$} & $-0.022 * * *$ & $-0.020 * * *$ & $-0.020 * * *$ & $-0.021 * * *$ & $-0.020 * * *$ & $-0.020 * * *$ & $-0.022 * * *$ & $-0.019 * * *$ & $-0.021 * * *$ & $-0.022 * * *$ & $-0.017 * *$ & $-0.021 * * *$ \\
\hline & $(0.004)$ & $(0.007)$ & $(0.005)$ & $(0.004)$ & $(0.007)$ & $(0.005)$ & $(0.004)$ & $(0.007)$ & $(0.005)$ & $(0.004)$ & $(0.007)$ & $(0.005)$ \\
\hline \multirow{2}{*}{$\begin{array}{l}\text { Log (Sales } \\
\text { growth) }\end{array}$} & $0.006^{* * *}$ & $0.078 * * *$ & $0.006 * * *$ & $0.006 * * *$ & $0.078 * * *$ & $0.006 * * *$ & $0.006 * * *$ & $0.078 * * *$ & $0.006 * * *$ & $0.006 * * *$ & $0.078 * * *$ & $0.006 * * *$ \\
\hline & $(0.001)$ & $(0.007)$ & $(0.001)$ & $(0.001)$ & (0.007) & $(0.001)$ & $(0.001)$ & $(0.007)$ & $(0.001)$ & $(0.001)$ & $(0.007)$ & $(0.001)$ \\
\hline \multirow[t]{2}{*}{$\log ($ FirmAge $)$} & $-0.193 * * *$ & $-0.149 * *$ & $-0.213 * * *$ & $-0.194 * * *$ & $-0.150 * *$ & $-0.215^{* * *}$ & $-0.192 * * *$ & $-0.148 * *$ & $-0.212 * * *$ & $-0.194 * * *$ & $-0.147 * *$ & $-0.214 * * *$ \\
\hline & $(0.038)$ & $(0.066)$ & $(0.048)$ & $(0.038)$ & $(0.066)$ & $(0.048)$ & $(0.039)$ & $(0.066)$ & $(0.049)$ & $(0.038)$ & $(0.066)$ & $(0.048)$ \\
\hline \multirow{3}{*}{$\begin{array}{l}\text { Log } \\
(\text { Patents }+1)\end{array}$} & $-0.113 * * *$ & $-0.137 * *$ & $-0.119 * * *$ & $-0.113 * * *$ & $-0.138 * *$ & $-0.119 * * *$ & $-0.119 * * *$ & $-0.136^{* *}$ & $-0.126^{* * *}$ & $-0.113 * * *$ & $-0.134 * *$ & $-0.118 * * *$ \\
\hline & & & & & & & & & & & & \\
\hline & $(0.030)$ & $(0.066)$ & $(0.034)$ & $(0.030)$ & $(0.066)$ & $(0.034)$ & $(0.029)$ & $(0.067)$ & $(0.034)$ & $(0.029)$ & $(0.067)$ & $(0.034)$ \\
\hline \multirow[t]{2}{*}{$\log (T M+1)$} & $-0.166^{* * *}$ & $-0.277 * * *$ & -0.062 & $-0.163 * * *$ & $-0.274 * * *$ & -0.061 & $-0.162 * * *$ & $-0.274 * * *$ & -0.057 & $-0.165 * * *$ & $-0.274 * * *$ & -0.065 \\
\hline & $(0.062)$ & $(0.102)$ & $(0.081)$ & $(0.062)$ & $(0.102)$ & $(0.080)$ & $(0.062)$ & $(0.102)$ & $(0.081)$ & $(0.062)$ & $(0.102)$ & $(0.081)$ \\
\hline $\log$ & 0.017 & $0.043^{*}$ & -0.006 & 0.019 & $0.044^{*}$ & -0.004 & 0.015 & $0.045^{*}$ & -0.012 & 0.018 & $0.047^{*}$ & -0.005 \\
\hline
\end{tabular}




\begin{tabular}{|c|c|c|c|c|c|c|c|c|c|c|c|c|}
\hline & $(0.019)$ & $(0.026)$ & $(0.028)$ & $(0.019)$ & $(0.026)$ & $(0.027)$ & $(0.019)$ & $(0.026)$ & $(0.028)$ & $(0.019)$ & $(0.026)$ & $(0.027)$ \\
\hline \multirow[t]{2}{*}{ Crisis } & $0.958 * * *$ & $0.679 *$ & $1.211 * * *$ & $0.869^{* * *}$ & $0.613^{*}$ & $1.117 * * *$ & $0.940 * * *$ & $0.617 *$ & $1.229 * * *$ & $0.913^{* * *} *$ & 0.567 & $1.178 * * *$ \\
\hline & $(0.276)$ & $(0.364)$ & $(0.422)$ & $(0.273)$ & $(0.358)$ & $(0.420)$ & $(0.274)$ & $(0.360)$ & $(0.417)$ & $(0.275)$ & $(0.361)$ & $(0.421)$ \\
\hline \multirow{3}{*}{$\begin{array}{l}\text { Return on } \\
\text { Equity }\end{array}$} & $-0.055 * * *$ & $-0.033 * * *$ & $-0.111^{* * *}$ & $-0.055^{* * *}$ & $-0.032 * * *$ & $-0.113^{* * *} *$ & $-0.055^{* * *}$ & $-0.032 * * *$ & $-0.110 * * *$ & $-0.055^{* * * *}$ & $-0.032 * * *$ & $-0.109^{* * *}$ \\
\hline & & & & & & & & & & & & \\
\hline & $(0.010)$ & $(0.008)$ & $(0.015)$ & $(0.010)$ & $(0.008)$ & $(0.015)$ & $(0.010)$ & (0.008) & $(0.015)$ & $(0.010)$ & (0.009) & $(0.015)$ \\
\hline Observations & 11,337 & 4,526 & 6,811 & 11,337 & 4,526 & 6,811 & 11,337 & 4,526 & 6,811 & 11,337 & 4,526 & 6,811 \\
\hline Year FE & YES & YES & YES & YES & YES & YES & YES & YES & YES & YES & YES & YES \\
\hline Industry FE & YES & YES & YES & YES & YES & YES & YES & YES & YES & YES & YES & YES \\
\hline
\end{tabular}

Notes: This table provides Cox estimations of proportional hazards for the probability of failure and time-to-failure for service and manufacturing industries, considering the three major ESG issue components. In all the regressions, we included industry and year fixed effects. All the variables are defined in the Appendix. The standard errors are shown in parentheses below the estimated coefficients. One, two, and three asterisks indicate statistical significance at the $10 \%, 5 \%$, and $1 \%$ levels, respectively. $* * * \mathrm{p}<0.01, * * \mathrm{p}<0.05, * \mathrm{p}<0.1$ 
In Table 12, we show the results of the Cox proportional model (specification 1) for crisis periods. We split our sample into subsamples for crisis and no crisis periods. The basic results indicated that ESG issues increased the probability of delisting and reduced the survival time in both "cold" and "hot" market periods. The results suggested that, during crisis periods, the impact of ESG issues on firms' probability of delisting almost doubled. This implied that, in crisis periods, firms should pay even greater attention to their ESG policies. Overall, our results supported our main analysis and the importance of our findings by incorporating the extra systemic risk of crisis periods.

Table 12. Estimates of ESG impact on firm exiting the market Controlling for crisis periods

\begin{tabular}{|c|c|c|c|}
\hline & (1) & (2) & (3) \\
\hline VARIABLES & $-\mathrm{t}$ & $-\mathrm{t}$ & $-\mathrm{t}$ \\
\hline \multirow[t]{2}{*}{ ESG Issues } & $0.253 * * *$ & $0.436^{*}$ & $0.241 * * *$ \\
\hline & $(0.066)$ & $(0.262)$ & $(0.068)$ \\
\hline \multirow[t]{2}{*}{$\log ($ Sales $)$} & -0.033 & 0.001 & -0.026 \\
\hline & $(0.038)$ & (0.099) & $(0.041)$ \\
\hline \multirow[t]{2}{*}{$(\log (\text { Sales }))^{2}$} & $-0.019 * * *$ & $-0.021 * *$ & $-0.020 * * *$ \\
\hline & $(0.004)$ & $(0.010)$ & $(0.004)$ \\
\hline \multirow[t]{2}{*}{ Log (Sales growth) } & $0.006 * * *$ & -0.042 & $0.006 * * *$ \\
\hline & $(0.001)$ & $(0.036)$ & $(0.001)$ \\
\hline \multirow[t]{2}{*}{ Log (FirmAge) } & $-0.218 * * *$ & -0.120 & $-0.237 * * *$ \\
\hline & $(0.038)$ & $(0.107)$ & $(0.041)$ \\
\hline \multirow[t]{2}{*}{ Log (Patents) } & $-0.210 * * *$ & $-0.178 * *$ & $-0.218 * * *$ \\
\hline & $(0.029)$ & $(0.074)$ & $(0.031)$ \\
\hline \multirow[t]{2}{*}{$\log (T M)$} & $-0.211 * * *$ & $-0.356 * *$ & $-0.187 * * *$ \\
\hline & $(0.062)$ & $(0.172)$ & $(0.066)$ \\
\hline \multirow[t]{2}{*}{ Log (Advertising) } & -0.021 & -0.013 & -0.022 \\
\hline & $(0.018)$ & $(0.048)$ & $(0.020)$ \\
\hline \multirow[t]{2}{*}{ Crisis } & $1.139 * * *$ & & \\
\hline & $(0.278)$ & & \\
\hline \multirow[t]{2}{*}{ Return on Equity } & $-0.064 * * *$ & $-0.040 * * *$ & $-0.097 * * *$ \\
\hline & $(0.009)$ & $(0.005)$ & $(0.014)$ \\
\hline
\end{tabular}


Chi-square test probability

Observations

Crisis

Industry FE
0.000

11,337

Overall Sample
0.000

1,252

Sub-sample in crisis periods
0.000

10,085

Sub-sample not in

crisis periods

Notes: This table provides Cox proportional hazards for the probability of failure and time-to-failure for crisis and no crisis periods. In all the regressions, we included industry and year fixed effects. All the variables are defined in the Appendix. The standard errors are shown in parentheses below the estimated coefficients. Robust standard errors are in parentheses. One, two, and three asterisks indicate statistical significance at the $10 \%, 5 \%$, and $1 \%$ levels, respectively. $* * * \mathrm{p}<0.01, * * \mathrm{p}<0.05, * \mathrm{p}<0.1$.

\subsubsection{Other robustness checks}

For further robustness purposes, we examined the relationship between ESG issues and firms' exiting due to negative acquisitions (Table A2 in the Appendix). We categorized as negative those firms with decreased share prices following the acquisition announcements. Our results documented that ESG issues weakened firms' market position and increased the probability of them being acquired, while firms without ESG issues had lower risk and were more likely to remain listed for longer periods. Our findings indicated that firms with ESG exposure, which were more prone to failure due to the reputational risks, chose acquisitions to avoid this fate. This result was stronger when we focused on corporate governance issues.

\subsection{Conclusions}

For this research, we used a dataset of US-listed firms and performed a dynamic empirical analysis, which associated ESG performance with public firms' market exiting profiles. We considered different types of firms' failure, including exiting due to acquisitions, and applied financial analysis to distinguish firms with strategical exits from those that were unable to remain in the market. We applied nonparametric, semiparametric, and parametric approaches of survival analysis to study the association between corporate sustainability and firms' market survival. We also considered 
the impact of the three major ESG components (EP, SP, and GP) and studied this relationship in service and manufacturing industries. Last but not least, we also examined whether our findings remained unaltered during crisis periods.

The findings indicated that firms with ESG issues faced a higher probability of exiting the market across all the determinants of delisting. The results remained unaltered even when we considered subsamples for crisis periods. In addition, we found that in manufacturing sector, where lower information asymmetry reduces adverse selection problems, ESG issues exhibit a greater influence on firms exiting profile. Also, our research provided evidence that firms with corporate governance issues face higher probability of being acquired by other companies than those without ESG issues.

Overall, the empirical results of this research showed how listed firms may be able to incorporate the benefits arising from ESG policies, considering firms' delisting mechanisms, and suggested how such incorporations may contribute to reducing the number of firms exiting the US market. In particular, it contributes to the literature by shedding light on firms' corporate sustainability performance as a non-financial characteristic that has substantial benefits for firms' market survival.

Lastly, there are interesting opportunities for future research. The number of firms that adopt ESG disclosure regulations is significant growth. Future research may study the impact of new ESG regulations on firms' risk management across industries. More important, there is still much to understand about ESG dynamics and how they affect firms' market profile. 


\section{Chapter 5 - Conclusions and Research proposals}

Firms in the modern business environment seek ways to stand out in order to become more competitive. Doing business in the usual way and thus, focusing only on profit outcomes does not have enough prerequisites to create the sustainability that modern companies need (Blower, 1997; Hart, 1997). The intense interest of literature on the sustainability issue, has stimulated firms' effort for further development of parts of their modern business strategies with respect to natural recourses and society (Cuesta and Valor, 2004). Nowadays, most companies try to integrate sustainability principles in their strategic thinking so as to expand the opportunities arising from their competitive environments ( $\mathrm{Du}$ et al., 2011). It is well acknowledged that corporate sustainability can be influenced by a broad number of factors, such as changes in legal and institutional regulations, business ethics or the direct impact on financial, operational, strategic and reputational risks (Godfrey, 2005).

In today's competitive environment, leading companies are recognizing that their issues are related to business processes, management practices, natural and social capital need to be measured, addressed and managed with transparency and accountability. Firms that integrate Environmental, Social and Governance (ESG) criteria into their corporate performance have positive outcomes (Waddock and Graves, 1997; Van Beurden and Gössling, 2008). ESG on firms' strategy is considered as a management quality and can create a competitive advantage (Ling et al., 2007), as it provides a strong connection between information and knowledge regarding accountability and transparency (Du Rietz, 2018). Policy makers form regulations taking into account the firms' ESG performance in an effort to ensure the stability of modern capital markets (Eccles and Klimenko, 2019). Bailey et al. (2000) argue the importance of firms' ESG reports in order to understand their corporate purpose, operational strength, efficiency, risk management and responsible strategy.

Another large strand of the literature (Wadhwa and Kotha, 2006; Miller et al., 2007) places special emphasis on the role of innovation in corporate sustainability. Also, Brown and Eisenhardt (1995), state that innovation is a firm's opportunity to meet new sustainability challenges. Innovation is the key to differentiate over their competitors (Porter, 1985) and to further develop (Galbreath,2013). So, innovation that creates sustainability is a business strategy that overcomes 
the traditional perception of doing business (Schumpeter, 1942; Daft, 1982; Grossman and Helpman, 1994; Eisenhardt and Brown, 1998), in order to increase profits. As a result, the firms' strategy focuses on green mentality, as innovation drives sustainability (Porter and van der Linde,1995a; Nidumolu et al., 2009; Eccles and Serafeim, 2013). The present thesis explores the importance of sustainability on modern firms' business strategies and particularly for those operating in the US environment.

The first chapter focuses on the discussion of the literature on corporate sustainability as a business strategy and presents all the important reasons in relation to ESG integration into business strategies. In particular, we examine the concept of Socially Responsible Investment (SRI) as a practice that involves the evaluation of Environmental, Social and Governance (ESG) criteria so that investors can make a responsible investment decision. In the last decades, the need for sustainability has become imperative, so SRI has attracted a lot of attention. Firms integrate sustainability in their business strategies as environmental, social and governance awareness is increasing (Pienitz and Vincent, 2000). So, firms with corporate sustainability attract ethical investments (Hoepner et al., 2016). In particular, investors use SRI in order to evaluate the sustainability and ethical influence of an investment decision based on firms' ESG reports. ESG provides information on firms' responsible management and its integration in business strategies can contribute to market share and to shareholder value creation by overcoming regulations and maximizing profits (impact investing). This happens either because firms choose to be responsible or under regulatory pressure (Van Marrewijk, 2003). But why is it important for firms to integrate ESG in their business strategy? Firstly, firms integrate ESG in their business strategy to increase their market performance. The more ethical a firm, the better its market performance and investors prefer investing their money in ethical companies, as these companies can attract more consumers with their ethical behavior (Eccles et al., 2014). Consumers choose responsible firms that disclose ESG information as they can be accountable and transparent. Secondly, firms that integrate ESG in their business strategy are greener and more ethical. So, they adopt green business strategies to avoid fines, overcome regulations and reduce the possibility to be penalized. Moreover, firms create value for their stakeholders and boost their reputation by establishing an ethical brand name. The companies that don't adopt the ESG criteria experience bad performance as they don't have access to private equity and have a high cost of capital (Crifo and Forget, 2013). Thirdly, firms 
that integrate ESG in their business strategy become more competitive, reduce risks (Godfrey et $a l ., 2009)$ and create a positive outcome on corporate financial performance (Edams, 2011). As a result, firms that disclose ESG information through transparent and accountable practices are more likely to achieve longevity. ESG is an integral part of a firm's strategy in order to attract more investors and create value for all the stakeholders.

The second chapter focuses on the impact of several aspects of innovation (patents, trademarks, R\&D) on corporate sustainability (ESG), as it is considered a controversial topic among economists and scholars. The dataset consists of 1,048 US firms between 2007 and 2016. During a preliminary literature review, we realized the absence of a systematic framework that explores the relation between sustainability and all aspects of innovation, which at the same time, would be flexible enough so as to be applicable to different firms and industries. So, this chapter is the first attempt to explore several aspects of innovation on sustainability. In this chapter, we develop testable hypotheses regarding the impact of innovation on firm's sustainable performance. Moreover, these hypotheses have been tested by using a panel with a large number of firm-year observations. The results point out that that all aspects of innovation play a significant role and indicate that both quantity and value of innovation proxied by $\mathrm{R} \& \mathrm{D}$, patents, trademarks, knowledge capital and organization capital greatly enhance corporate sustainability. There is evidence that these effects become even stronger during periods of financial crisis. This chapter further supports its findings using propensity matching score and instrumental variable analysis to show that these findings are causal.

The third chapter focuses on the impact of ESG issues on firms' market exiting. The dataset consists of 1.585 US listed firms between 2007 and 2016. The dataset consists of 1,585 US firms between 2007 and 2016. During a preliminary literature review, we realized the absence of a systematic framework that explores the relation between ESG performance and firms' market longevity that can be applicable to different firms and industries. So, this chapter is the first attempt to explore the importance of ESG performance on public firms' market exiting profile. In this chapter, we apply nonparametric, semiparametric and parametric approaches of survival analysis in order to study the association between corporate sustainability and firms' market survival. We consider different types of firms' failure including exiting in the case of M\&A. Based on financial 
criteria, we apply a financial analysis to distinguish firms with successful exits from those who do not meet the requirements to remain in the markets. Moreover, we consider the impact of ESG on firms' exiting mechanism and study this relation in both Service and Manufacturing Industries. Lastly, we examine the impact of economic crisis on these findings. The results point out that firms with ESG issues faced a higher probability of exiting the market across all the determinants of delisting. The results remained unaltered even when we considered subsamples for crisis periods. In addition, we found that in manufacturing sector, where lower information asymmetry reduces adverse selection problems, ESG issues exhibit a greater influence on firms exiting profile. Also, our research provided evidence that firms with corporate governance issues face higher probability of being acquired by other companies than those without ESG issues.

Findings of this thesis may be used to raise awareness on the importance of ESG in the modern competitive business environment. The current framework will offer new insights and help firms develop and design business strategies according to ESG. This emphasises the need for ESG reports in order to highlight accountable and transparent business strategies. Research findings may be used to assist investors in incorporating ESG evaluation into their SRI, consumers in finding the firm that represents their ethical values and firms in integrating sustainability into their business strategies. Such an endeavor could help managers to gain suitable insights in their effort to predict which variables are closely related to business sustainability in advance and, moreover, which tests and models are likely to contribute the most to their pace for environmental, social and economic improvements. It is undeniable that firms should transform their business strategy based on corporate sustainability in order to become competitive. Therefore, this thesis could benefit all stakeholders.

The researcher may expect that the findings of this thesis establish baseline data that could be a source of general guidance to stimulate future research in this area and further fill the identified research gap. Future research on sustainability as a firm's strategy should be conducted as ESG is a new concept and more research is needed. In Europe, the directive 2014/95 / EU came into force in the financial year that began on 1 January 2017. Thus, now firms that operate in the EU environment are forced to publish ESG reports. However, in the USA this is still on a voluntary basis. So it will be important to examine the behavior of US firms that have subsidiaries in the EU, how easily they will comply with the directive and what sustainability information they will 
publish. Also, it will be important to examine the difference in the corporate performance of EU firms that have integrated ESG into their business strategy before and after the directive application. 


\section{References}

Acs, Z. J. and Audretsch D. B. (1987). Innovation, Market Structure, and Firm Size. The Review of Economics and Statistics, 69(4), 567-574. doi:10.2307/1935950.

Aghion, P., Dewatripont, M., Du, L., Harrison, A. E. and Legros, P. (2015). Industrial Policy and Competition. American Economic Journal: Macroeconomics, 7(4), 1-32. http://dx.doi.org/10.1257/mac.20120103.

Albuquerque, R., Durnev, A. and Koskinen, Y., (2019). Corporate social responsibility and firm risk: theory and empirical evidence. Management Science, 65(10), 4451-4949. doi: 10.1287/mnsc.2018.3043.

Allegrezza, S. and Guarda-Rauchs, A. (1999). The determinants of trademarks deposits: aneconometric investigation. Econ. Appliquée, 52(2), 51-68.

Alexander GJ and Buchholz RA. (1978). Corporate social responsibility and stock market performance. Academy of Management Journal, 21(3), 479-486. doi:10.2307/255728.

Alhadab, M., Clacher, I. and Keasey, K. (2015). Real and accrual earnings management and IPO failure risk. Accounting and Business Research, 45(1), 55-92.

Allison, P.D. (2000). Survival Analysis Using the SAS System: A Practical Guide, SAS Institute,Cary, NC.

Ambec, S. and Lanoie, P. (2008). Does It Pay to Be Green? A Systematic Overview. Academy of Management Perspectives, 22(4), 45-62. doi:10.5465/amp.2008.35590353.

Aouadi, A. and Marsat, S. (2016). Do ESG controversies matter for firm value? Evidence from international data. Journal of Business Ethics, 151(4), 1027-1047. doi:10.1007/s10551-016-3213-8. 
Amel-Zadeh, A. and Serafeim, G. (2018). Why and how investors use ESG information: Evidence from a global survey. Financial Analysts Journal, 74(3), 87-103.

Aragón-Correa, J. A. and Sharma, S. (2003). A Contingent Resource-Based View of Proactive Corporate Environmental Strategy. The Academy of Management Review, 28(1), 71-88. doi:10.2307/30040690.

Aras, G. and Crowther, D. (2009). Corporate Sustainability Reporting: A Study in Disingenuity?. Journal of Business Ethics, 87(1), 279-288.

Armitage, S., and Marston, C. (2007). Corporate Disclosure and the Cost of Capital: the views of Finance Directors, London.

Ashrafi, M., Acciaro, M., Walker, T. R., Magnan, G. M., and Adams, M. (2019). Corporate sustainability in Canadian and US maritime ports. Journal of Cleaner Production, 220, 386-397. doi: 10.1016/j.jclepro.2019.02.098.

Atkeson, A. and Kehoe, P. J. (2005). Modeling and measuring organization capital. Journal of Political Economy, 113(5), 1026-1053. doi:10.1086/431289.

Avetisyan, E., and Hockerts, K. (2017). The consolidation of the ESG rating industry as an enactment of institutional retrogression. Business Strategy and the Environment, 26(3), 316-330.

Bailey, D., Harte, G. and Sugden, R. (2000). Corporate disclosure and the deregulation of international investment. Accounting, Auditing and Accountability Journal, 13(2), 197-218.

Bain, J. S. (1951). Relation of profit rate to industry concentration: American manufacturing 19361940. Quarterly Journal of Economics, 65(3), 293-324. doi:10.2307/1882217.

Bain, J. S. (1956). Barriers to New Competition. Harvard University Press, Cambridge, MA. 
Barbieri, J. C., Vasconcelos, I. F. G., Andreassi, T. and Vasconcelos, F. C. (2010). Inovação e Sustentabilidade: Novos Modelos eProposições. Revista de Administração e Estratégia, 50(2), 146-154.

Barney, J.B. (1991). Firm Resources and Sustained Competitive Advantage. Journal of Management, 17(1), 99-120.

Barnett, M.L. and Salomon, R.M. (2006). Beyond dichotomy: The curvilinear relationship between social responsibility and financial performance. Strateg. Manag. J., 27(11), 1101-1122.

Bauer, R., Koedijk, K. and Otten, R., (2005). International evidence on ethical mutual fund performance and investment style. Journal of Banking and Finance, 29(7), 1751- 1767.

Bauer R., Derwall J. and Hann, D. (2009). Employee relations and credit risk. SSRN Electronic Journal. doi: $10.2139 / \mathrm{ssrn} .1483112$.

Baumol, W. J. (1982). Contestable markets: An uprising in the theory of industry structure. American Economic Review, 72(1), 1-15.

Baumol, W. (1991). Perfect Markets and Easy Virtue: Business Ethics and the Invisible Hand. Basil Blackwell, Oxford.

Bernstein, S. (2015). Does Going Public Affect Innovation?. Journal of Finance, 70(4), 13651403. doi:10.1111/jofi.12275.

Besen, S. M. and Raskind L. J. (1991). An introduction to the law and economics of Intellectual. Journal of Economic Perspectiv, 5(1), 3-27. doi:10.4337/9781782540465.00005.

Beurden, P. V. and Gossling, T. (2008). The Worth of Values - A Literature Review on the Relation Between Corporate Social and Financial Performance. Journal of Business Ethics, 82(2), 407-424.

Bhat, V.N. (1998). Does environmental compliance pay?. Ecotoxicology, 7(4), 221-225. 
Bhattacharya, CB. and Xueming, L. (2006). Corporate social responsibility, customer satisfaction and market value. Journal of Marketing, 70(4), 1-18.

Block, J.H., De Vries, G., Schumann, J. H. and Sandner (2014). Trademarks and venture capital valuation. Journal of Business Venturing, 29(4), 525-542. doi:10.1016/j.jbusvent.2013.07.006.

Bloom, P. and Kotler, P. (1975). Strategies for High Market-Share Companies. Harvard Business Review, 53(6), 63-72.

Blowers, A. (1997). Environmental Policy: Ecological Modernisation or Risk Society?. Urban studies, 34(5-6), $845-871$.

Boiral, O. (2002). Tacit knowledge and environmental management. Long Range Planning, 35(3), 291-317. doi:10.1016/S0024-6301(02)00047-X.

Bonini, S and Görner, S. (2011). The business of sustainability: McKinsey Global Survey Results.

Borenstein, S., \& Zimmerman, M. B. (1988). Market incentives for safe commercial airline operation. The American Economic Review, 78(5), 913-935.

Botosan, C. A. (2006). Disclosure and the cost of capital: what do we know?. Accounting and Business Research, 36(1), 31-40. doi:10.1080/00014788.2006.9730042.

Brammer, S. and Millington, A. (2008). Does it pay to be different? An analysis of the relationship between corporate social and financial performance. Strategic Management Journal, 29(12), 1325-1343. doi:10.1002/smj.714.

Brammer, S. and Pavelin, S. (2008). Factors influencing the quality of corporate environmental disclosure. Business Strategy and the Environment, 17(2), 120-136.

Brill, J. A. and Reder, A. (1993). Investing from the Heart - The Guide to Socially Responsible Investments and Money Management. Crown Publishers, New York. 
Brill, H., Brill J. A. and Feigenbaum, C. (1999). Investing with Your Values: Making Money and Making a Difference. Bloomberg Press, Princeton, NJ.

Brown, TJ and Dacin, PA (1997). The company and the product: corporate associations and consumer product responses. Journal of Marketing, 61(1), 68-84. DOI: 10.2307/1252190

Brown, S. L. and Eisenhardt, K. M. (1995). Resources, Firms, and Strategies: A Reader in the Resource-based Perspective. Academy of Management Review, 20(2), 343-378.

Brown, J. R., Fazzari, S. M. and Petersen, B. C. (2009). Financing innovation and growth: Cash flow, external equity, and the 1990s r\&d boom. Journal of Finance, 64(1), 151-185. doi:10.1111/j.1540-6261.2008.01431.x.

Bruyn, S.T. (1987). The Field of Social Investment. Cambridge University Press, Cambridge.

Buzzell, R.D., Gale, B.T. and Sultan, R.G.M. (1975). Market Share - A Key to Profitability. Harvard Business Review, 53(1), 97-106.

Cahan, S. F., Chen, C., Chen, L., and Nguyen, N. H. (2015). Corporate social responsibility and media coverage. Journal of Banking and Finance, 59, 409 - 422. doi:10.1016/j.jbankfin.2015.07.004.

Camejo, P. (2002). The SRI Advantage: Why Socially Responsible Investing has Outperformed Financially. New Society Publishers, Gabriola, BC.

Campbell, D., Craven, B. and Shrives, P. (2003). Voluntary social reporting in three FTSE sectors: a comment on perception and legitimacy. Accounting, Auditing \& Accountability Journal, 16(4), 558-582.

Capelle-Blancard, G. and Petit, A. (2017). Every Little Helps? ESG News and Stock Market Reaction. Journal of Business Ethics, 157(11), doi:10.1007/s10551-017-3667-3 
Carpentier, Cécile \& Suret, Jean-Marc. (2007). The Survival and Success of Penny Stock IPOs: Canadian Evidence.

Carrión-Flores, C.E. and Innes, R. (2010). Environmental innovation and environmental performance. Journal of Environmental Economics and Management, 59(1), 27-42. doi:10.1016/j.jeem.2009.05.003.

Cardozo, R., McLaughlin, K., Harmon, B., Reynolds, P. and Miller, B. (1993). Product-Market Choices and Growth of New Businesses. Journal of Product Innovation Management, 10(4), 331340. doi:10.1111/1540-5885.1040331.

Carroll, A.B. (1991). The pyramid of corporate social responsibility: Toward the moral management of organizational stakeholders. Business Horizons, 34(4), 39-48. doi: 10.1016/00076813(91)90005-G.

Carroll, A. B. (2009). A History of Corporate Social Responsibility: Concepts and Practices. The Oxford Handbook of Corporate Social Responsibility. doi:10.1093/oxfordhb/9780199211593.003.0002.

Carroll, A. B., Lipartito, K. J., Post, J. E. and Werhane, P. H., (2012). Corporate Responsibility: The American Expe- rience. Cambridge University Press, Cambridge

Carson, R. (1962). Silent Spring. Boston: Houghton Mifflin Company; Cambridge: The Riverside Press, 1962.

Castaldi, C., (2018). To trademark or not to trademark: The case of the creative and cultural industries. Research Policy, 47(3), 606-616.

Castaldi, C. and Giarratana, M.S., (2018). Diversification, Branding, and Performance of Professional Service Firms. Journal of Service Research, 21(3), 353-364.

Caulkin, S. (2002). Good thinking, bad practice. The Observer. 
Cengiz, CBs, Braun, D. and von Nitzsch, R. (2010). Alpha-Vehikel oder Preis fur das Gute Gewissen? Eine Performanceanalyse ethischer Investments. Corporate Finance biz, 1(4),263-271.

Chan, L.K.C., Lakonishok, J. and Sougiannis, T. (2001). The stock market valuation of research and development expenditures. Journal of Finance, 56(6), 2431-2456. doi:10.1111/00221082.00411 .

Chaney, P. K., \& Philipich, K. L. (2002). Shredded reputation: The cost of audit failure. Journal of Accounting Research, 40(4), 1221-1245.

Chava, Sudheer. (2011). Environmental Externalities and Cost of Capital. Management Science. 60(9), 2223-2247. doi:10.2139/ssrn.1677653.

Chemmanur, TJ. and Signori, A. and Vismara, S. (2019). The Exit Choices of European Private Firms: A Dynamic Empirical Analysis. Available at SSRN: https://ssrn.com/abstract=2530987 or http://dx.doi.org/10.2139/ssrn.2530987

Chen, Y.S. (2008). The positive effect of green intellectual capital on competitive advantages of firms. Journal of Business Ethics, 77(3), 271-286. doi: 10.1007/s10551-006-9349-1.

Cheng, B., Ioannou, I. and Serafeim, G. (2014). Corporate Social Responsibility and Access to Finance. Strategic Management Journal, 35(1), 1-23. https://doi.org/10.1002/smj.2131.

Cheynel, E. (2013). A theory of voluntary disclosure and cost of capital. Review of Accounting Studies, 18(4), 987-1020. doi:10.1007/s11142-013-9223-1.

Cho, C. H., Roberts, R. W., \& Patten, D. M. (2010). The language of US corporate environmental disclosure. Accounting, Organizations and Society, 35, 431-443.

Ciccotello, C., (2014). The state of the public corporation: not so much an eclipse as an evolution. Journal of Applied Corporate Finance, 26, 8-21. 
Clark, G. and Viehs, M. (2014). The Implications of Corporate Social Responsibility for Investors: An Overview and Evaluation of the Existing CSR Literature. SSRN Electronic Journal. 10.2139/ssrn.2481877.

Clarkson, M.E. (1995). A stakeholder framework for analyzing and evaluating corporate social performance. Acad. Manag. Rev., 20(1), 92-117.

Clementino, E. and Perkins, R. (2020). How Do Companies Respond to Environmental, Social and Governance (ESG) ratings? Evidence from Italy. Journal of Business Ethics. doi:10.1007/s10551-020-04441-4.

Cockburn, I. and Griliches, Z. (1988). Industry Effects and Appropriability Measures in the Stock Market's Valuation of R\&D and Patents. The American Economic Review, 78(2), 419-423. doi:10.1007/s10551-020-04441-4.

Collin, S. (2009). The Value of Environmental, Social and Governance Factors for Foundation Investments. London: EIRIS Foundation.

Cornell B, Shapiro AC (1987) Corporate stakeholders and corporate finance. Financial Management, 16, 5-14.

Corrado, C.A. and Hulten, C.R. (2010). Measuring Intangible Capital: How Do You Measure a "Technological Revolution". American Economic Review, 100(2), 99-104. http://www.jstor.org/stable/27804971.

Cowton, C.J. (1994). The Development of Ethical Investment Products. In Ethical Conflicts in Finance, edited by A. R. Prindl and B. Prodhan. Oxford: Blackwell.

Cowton, C.J. (1998). Socially responsible investment. In Encyclopedia of Applied Ethics, edited by R. Chadwick. San Diego, CA: Academic Press. 
Cox, D.R. (1972). Regression Models and Life Tables. Journal of the Royal Statistical Society. B34: 187-220.

Cox, P., Brammer, S. and Millington, A. (2004). An empirical examination of institutional investor preferences for corporate social responsibility. Journal of Business Ethics, 52(1), 27-43.

Cpg, Fmcg and Retail (2018). Was 2018 the Year of the Influential Sustainable Consumer?. Nielsen Report.

Cremers, K.J.M. and Nair, V.B. (2005). Governance mechanisms and equity prices. Journal of Finance, 60(6), 2859-2894. doi:10.1111/j.1540-6261.2005.00819.x.

Cremers, M. and Ferrell, A. (2014). Thirty years of shareholder rights and firm value. Journal of Finance, 69(3), 1167-1196. doi:10.1111/jofi.12138.

Crifo, P., and Forget, V.D. (2013), Think Global, Invest Responsible: Why the Private Equity Industry Goes Green. Journal of Business Ethics, 116(1), pp. 21-48.

Czerwonka, M. (2011).Inwestycje odpowiedzialne społecznie (SRI) - inwestowanie alternatywne. Finanse, 1(4), 135-154.

Cuesta, M. and Valor, C. (2004). Fostering corporate social responsibility through public initiative: from the EU to the Spanish Case. Journal of Business Ethics, 55 (3), 229-275.

Cuesta, M. and Valor, C. (2013). Evaluation of the environmental, social and governance information disclosed by Spanish listed companies. Social Responsibility Journal, 9(2), 220-240. doi:10.1108/SRJ-08-2011-0065.

Daft, R. (1982). Bureaucratic versus nonbureaucratic structure and the process of innovation and change. Research in the Sociology of Organizations, 1, 129-166. 
Dando, N. and Swift, T. (2003). Transparency and assurance: minding the credibility gap. Journal of Business Ethics, 44(2), 195-2002.

Dawkins, C. and Ngunjiri, F.W. (2008). Corporate social responsibility reporting in south Africa: a descriptive and comparative analysis. Journal of Business Communication, 45(3), 286-307.

Dean, T. J. and Brown, R. L. (1995). Pollution Regulation as a Barrier to New Firm Entry: Initial Evidence and Implications for Future Research. Academy of Management Journal, 38(1), 288303. doi: $10.5465 / 256737$.

De Colle, S., and York, J. G. (2009). Why wine is not glue? The unresolved problem of negative screening in socially responsible investing. Journal of Business Ethics, 85(1), 83-95.

Deng, X., Kang, JK. and Sin Low, B., (2013). Corporate social responsibility and stakeholder value maximization: Evidence from mergers. Journal of Financial Economics, 110 (1), 87-109.

Derwall, J., Guenster, N., Bauer, R. and Koedijk, K., (2005). The eco-efficiency premium puzzle. Financial Analysts Journal, 61(2), 51-63. https://ssrn.com/abstract=713861.

Derwall, J. (2007). The economic virtues of SRI and CSR. Erasmus Research Institute of Management (ERIM).

Derwall, J., Koedijk, K.C.G. and Horst, J.T. (2011). A tale of values-driven and profit-seeking social investors. Journal of Banking \& Finance, 35 (8), 2137-2147.

Dimson, E., Karakaş, O. and Li, X. (2015). Active Ownership. Review of Financial Studies, 28(12), 3225-3268. doi:10.1093/rfs/hhv044.

Domini, A. L. and Kinder, P.D. (1986). Ethical Investing. Addison-Wesley, Reading, MA.

Domini, A. (2001). Socially Responsible Investing: Making a Difference and Making Money. Dearborn Trade, Chicago, IL. 
Donaldson, T. and Preston, L.E. (1995). The stakeholder theory of the corporation: concepts, evidence, and implications. Academy of Management Review, 20(1), 65-91.

Doidge, C., Karolyi, G. A. and Stulz, R. M. (2017) ‘The U.S. listing gap', Journal of Financial Economics, 123(3), pp. 464-487.

Dowell, G., Hart, S. and Yeung, B., (2000). Do corporate global environmental standards create or destroy market value?. Management Science, 46(8), 1059-1074.

Du, R.S., Bhattacharya, C.B. and Sen, S. (2011). Corporate social responsibility and competitive advantage: overcoming the trust barrier. Management Science, 57(9), 1528-1545.

Du, R.S. (2018). Information vs knowledge: Corporate accountability in environmental, social, and governance issues. Account. Audit. Account. J., 31(2), 586-607.

doi:10.1108/AAAJ-01-2013-1198

Dye, R.A. (1985). Disclosure of Nonproprietary Information. Journal of Accounting Research, 23(1), 123-145. doi:10.2307/2490910.

Dyllick, T. and Hockerts, K. (2002). Beyond the Business Case for Corporate Sustainability. University of St.Gallen. doi:11.10.1002/bse.323.

Eccles, RG and Krzus, MP. (2010). One Report: Integrated Reporting for a Sustainable Strategy. Wiley: NJ.

Eccles, R.G. and Serafeim, G. (2013). The performance frontier: Innovating for a sustainable strategy. Harvard Business Review, 91(5), 50-56, 58, 60, 150.

Eccles, RG and Serafeim G. (2014). Corporate and integrated reporting: a functional perspective. SSRN Electronic Journal. doi:10.2139/ssrn.2388716. 
Eccles, R.G., Ioannou, I. and Serafeim, G. (2014). The impact of corporate sustainability on organizational processes and performance. Management Science, 60(11), 2835-2857. doi:10.1287/mnsc.2014.1984.

Eccles, R.G. and Viviers, S. (2011). The Origins and Meanings of Names Describing Investment Practices that Integrate Consideration of ESG Issuesin the Academic Literature. Journal of Business Ethics, 104(3), 389-402.

Eccles, R.G. and Klimenko S. (2019). The Investor Revolution, Harverd Business Review, 97(3), 106-116.

Edmans, A. (2011). Does the stock market fully value intangibles? Employee satisfaction and equity prices. Journal of Financial Economics, 101(3), 621-640.

doi:10.1016/j.jfineco.2011.03.021.

Eisenhardt, K.M. and Brown, S.L. (1998). Patching: restitching business portfolios in dynamic markets. Harvard Business Review, 77(3), 72-82.

Eisfeldt, A. L. and Papanikolaou, D. (2013). Organization capital and the cross-section of expected returns. Journal of Finance, 68(4), 1365-1406. doi:10.1111/jofi.12034.El.

Eisfeldt, A.L. and Papanikolaou, D. (2014). The Value and Ownership of Intangible Capital. American Economic Review, 104(5),189-94.

Elke, H. and Brouwers, J. B. (2010). Corporate Sustainability and Innovation in SMEs. Business Strategy and the Environment, 19(7), 417-435.

Elkington, J. (1998). Partnerships from cannibals with forks: The triple bottom line of 21st-century business. Environ. Qual. Manag., 8(1), 37-51. 
Endrikat, J., Guenther, E. and Hoppe, H. (2014). Making sense of conflicting empirical findings: A meta-analytic review of the relationship between corporate environmental and financial performance. European Management Journal, 32(5), 735-751. doi:10.1016/j.emj.2013.12.004.

Espenlaub, S., Khurshed, A., and Mohamed, A. (2012). IPO Survival in a Reputational Market. Journal of Business Finance an Accounting, 39(3-4), 427-463. doi:10.1111/j.14685957.2012.02280.x.

European Social Investment Forum - Eurosif (2003). Socially Responsible Investment among European Institutional Investors, Eurosif Report, Paris. Available at:

http://www.eurosif.org/wp-content/uploads/2014/04/eurosif_srireprt_2003_all.pdf

(Accessed: 12 June 2020).

European Social Investment Forum - Eurosif (2006). European SRI Study 2006, Eurosif Report, Paris. Available at:

http://www.eurosif.org/wp-content/uploads/2014/04/eurosif_sristudy_2006_complete.pdf (Accessed: 12 June 2020).

European Social Investment Forum - Eurosif (2014). European SRI study 2014. Eurosif Report, Paris. Available at:

http://www.eurosif.org/wp-content/uploads/2014/09/Eurosif-SRI-Study-20142.pdf (Accessed: 12 June 2020).

Fama, E. F., and K. R. French. (2004). The Capital Asset Pricing Model: Theory and Evidence. Journal of Economic Perspectives, 18(3), 25-46.

Fama, E. F., and French, K. R. (2013). A Four-Factor Model for the Size, Value, and Profitability Patterns in Stock Returns. SSRN Electronic Journal. doi:10.2139/ssrn.2287202.

Farber, H., and Hallock, K. (2009). The changing relationship between job loss announcements and stock prices: 1970-1999. Labour Economics, 16(1), 1-11. 
Fatemi, A., Fooladi, I. and Tehranian, H. (2015). Valuation effects of corporate social responsibility. Journal of Banking and Finance, 59(3), 182-192.

doi:10.1016/j.jbankfin.2015.04.028.

Fehrenbacher, S. (2001). Put your money where your moral are: A guide to value - based investing. Broadman and Holdman Publishers, Nashville, TN.

Flammer, C. (2015). Does Corporate Social Responsibility Lead to Superior Financial Performance? A Regression Discontinuity Approach. Management Science, 61(11), 2549-2568. doi:10.1287/mnsc.2014.2038.

Fleischman, G. M., Johnson, E. N., Walker, K. B., and Valentine, S. R. (2019). Ethics versus outcomes: Managerial responses to incentive-driven and goal-induced employee behavior. Journal of Business Ethics, 158(4), 951-967.

Fombrun, C. and Shanley, M. (1990). What's in a Name? Reputation Building and Corporate Strategy. Academy of Management Journal, 33(2), 233-258. doi:10.2307/256324.

Francis, R. and Armstrong, A. (2003). Ethics as a risk management strategy: the Australian experience. Journal of Business Ethics, 45(4) 375-385.

Francis, J., LaFond, R., Olsson, P.M., and Schipper, K. (2004). Costs of Equity and Earnings Attributes. The Accounting Review, 79(4), 967-1010.

doi:10.2308/accr.2004.79.4.967

Freeman, R.E. (1984). Strategic Management: A Stakeholder Perspective. Pitman: Boston, MA, USA

Freeman, R. E., Parmar, B. L., Harrison, J. S., Wicks, A. C., Purnell, L., and de Colle, S. (2010). Stakeholder Theory:The State of the Art. The Academy of Management Annals, 4(1), 403-445. doi:10.1080/19416520.2010.495581 
Friedman, M. (1970) The social responsibility of the corporation is to increase its profits. The New York Times Magazine, 33, 122-126.

Freeman, RE. (2010). Strategic management: a stakeholder approach. Cambridge University Press, Cambridge.

Friedman, A.L., and Miles, S. (2001). Socially responsible investment and corporate social and environmental reporting in the UK: an exploratory study. British Accounting Review, 33(4), 523548.

Galbreath, J. (2013). ESG in Focus: The Australian Evidence. Journal of Business Ethics, 118 (3), 529-541.

Gao, X., Ritter, J. R., \& Zhu, Z. (2013). Where Have All the IPOs Gone?. Journal of Financial and Quantitative Analysis, 48(06), 1663-1692. doi:10.1017/s0022109014000015.

Gerakos, J., Lang, M. and Maffett, M., (2013). Post-listing performance and private sector regulation: The experience of London's Alternative Investment Market. Journal of Accounting and Economics, 56, 189-215.

Germán, G. and Philippon, T. (2017). Declining Competition and Investment in the US. NBER Working Papers 23583, National Bureau of Economic Research, Inc. doi:10.3386/w23583.

Geroski, P. A. (1995). What do we know about entry?. International Journal of Industrial Organization, 13(4), 421-440. doi:10.1016/0167-7187(95)00498-x.

Ghoul, S., Guedhami, O., Kwok, C.C.Y. and Mishra, D.R. (2011). Does corporate social responsibility affect the cost of capital?. Journal of Banking and Finance, 35(9), 2388-2406.

Godfrey, P.C. (2005). The relationship between corporate philanthropy and shareholder wealth: A risk management perspective. Academy of Management Review, 30(4), 777-798. doi:10.5465/AMR.2005.18378878. 
Godfrey, P.C., Merrill, C.B., and Hansen, J.M., (2009). The relationship between corporate social responsibility and shareholder value: An empirical test of the risk management hypothesis. Strategic Management Journal, 30(4), 425-445.

Gompers, P. A. (1995). Optimal Investment, Monitoring, and the Staging of Venture Capital. The Journal of Finance, 50(5), 1461-1489. doi:10.1111/j.1540-6261.1995.tb05185.x.

Grant, R. M. (1996). Toward a Knowledge-Based Theory of the Firm. Strategic Management Journal, 17 (Winter Special Issue: Knowledge and the Firm),109-122. doi:10.2307/2486994.

Gray, R., Kouhy, R. and Lavers, S. (1995). Corporate social and environmental reporting: a review of the literature and a longitudinal study of UK disclosure. Accounting, Auditing and Accountability Journal, 8(2), 47-77.

Greening, DW and Turban, DB (2000). Corporate social performance as a competitive advantage in attracting a quality workforce. Business and Society, 39(3),254-280.

Grossman, G.M. and Helpman, E. (1994). Endogenous Innovation in the Theory of Growth. Journal of Economic Perspectives, 8(1), 23-44. doi:10.1257/jep.8.1.23.

Grullon, G., Larkin, Y. and Michaely, R., (2015). The disappearance of public firms and the changing nature of U.S. industries. Unpublished working paper, Rice University, Houston, TX.

Gu, F. (2005). Innovation, future earnings, and market efficiency. Journal of Accounting, Auditing and Finance, 20(4), 385-418. doi:10.1177/0148558x0502000405.

Guay, T, Doh, J.P. and Sinclair, G. (2004). Non-governmental Organizations, Shareholder Activism, and Socially Responsible Investments: Ethical, Strategic, and Governance Implications. Journal of Business Ethics, 52(1), 125-39. 
Guenther, E., Hoppe, H. and Poser, C. (2007). Environmental corporate social responsibility of firms in the mining and oil and gas industries. Current status quo of reporting following GRI guidelines. Greener Management International, 53, 7-53.

Gutierrez, R. G., S. L. Carter, and D. M. Drukker. (2001). sg160: On boundary-value likelihoodratio tests. Stata Technical Bulletin 60: 15-18. Reprinted in Stata Technical Bulletin Reprints, vol. 10, pp. 269-273. College Station, TX: Stata Press.

Hall, R. (1992). The Strategic Analysis of Intangible Issues. Strategic Management Journal, 13(2), $135-144$.

Hall, B.H., Jaffe, A. and Trajtenberg, M. (2005). Market value and patent citations. RAND Journal of Economics, 36(1), 16-38.

Hall, J.K., Daneke, G. A. and Lenox, M. J. (2010). Sustainable development and entrepreneurship: Past contributions and future directions. Journal of Business Venturing, 25(5), 439-448.

Haller, K., Lee, J. and Cheung, J. (2020). Meet the 2020 consumers driving change. IBM Report.

Hamilton, S., Jo, H., Statman, M., 1993. Doing well while doing good? The investment performance of socially responsible mutual funds. Financial Analysts Journal 49, 62-66.

Hammond, S.A. and Slocum, J.W. (1996). The impact of prior firm financial performance on subsequent corporate reputation. J. Bus. Ethics, 15(2), 159-165.

Hanks, S.H., Watson, C.J., Jansen, E. and Chandler, G.N. (1993). Tightening the Life-cycle Construct: A Taxonomic Study of Growth Stage Configurations in High-technology Organizations. Entrepreneurship Theory and Practice, 18(2), 5-29.

Harrington, J.C. (1992). Investing with Your Conscience: How to Achieve High Returns Using Socially Responsible Investing. John Wiley and Sons, New York. 
Harrison, J.S. and Wicks, A.C. (2013). Stakeholder Theory, Value, and Firm Performance. Business Ethics Quarterly, 23(1), 97-124. https://doi.org/DOI: 10.5840/beq20132314.

Hart, S.L. (1995). A Natural-Resource-Based the Firm. Academy of Management Review, 20(4), 986-1014.

Hart, S.L., and Ahuja, G. (1996). Does It Pay To Be Green? An Empirical Examination Of The Relationship Between Emission Reduction And Firm Performance. Business Strategy and the Environment, 5(1), 30-37. doi:10.1002/(sici)1099-0836(199603)5:1<30::aid-bse38>3.0.co;2-q.

Hart, S.L. (1997). Beyond greening: strategies for a sustainable world. Harvard Business Review, 75(1), 66-76.

Hart, S.L. and Dowell, G. (2011). Invited Editorial: A natural-resource-based view of the firm fifteen years after. Journal of Management, 37(5), 1464-1479.

Heal, GM. (2004). Corporate Social Responsibility - an Economic and Financial Framework. Available at SSRN: https://ssrn.com/abstract=642762 or http://dx.doi.org/10.2139/ssrn.642762

Heal, G. M., (2008). When Principles Pay: Corporate Social Responsibility and the Bottom Line. Columbia University Press, New York

Heeley, M.B., Matusik, S. F. and Jain, N. (2007). Innovation, appropriability, and the underpricing of initial public offerings. Academy of Management Journal, 50(1), 209-225. doi:10.5465/AMJ.2007.24162388.

Helfat, C.E. (1994). Firm-Specificity in Corporate Applied R\&D. Organization Science, 5(2), 173-184. doi:10.1287/orsc.5.2.173.

Hensler, D., Rutherford, R. and Springer, T. (1997), The survival of initial public offerings in the aftermarket, Journal of Financial Research,. 20, 93-110. 
Higgins, C., Stubbs, W. and Love, T. (2014). Walking the talk(s): organisational narratives of integrated reporting. Accounting, Auditing and Accountability Journal, 27(7), 1090-1119. doi:10.1108/AAAJ-04-2013-1303.

Hill, R.P., Ainscough,T., Shank, T. and Manullang, D. (2007). Corporate social responsibility and socially responsible investing: A global perspective. Journal of Business Ethics, 70(2), 165-174. doi:10.1007/s10551-006-9103-8.

Hillman, A. J. and Keim, G.D. (2001). Shareholder value, stakeholder management, and social issues: What's the bottom line?. Strategic Management Journal, 22(2), 125-139.

Hirsch, B.T. (1990). Market structure, union rent seeking, and firm profitability. Economics Letters, 32(1), 75-79. doi:10.1016/0165-1765(90)90052-3.

Hirshleifer, D., Hsu, P.H. and Li, D. (2013). Innovative efficiency and stock returns. Journal of Financial Economics, 107(3), 632-654. doi:10.1016/j.jfineco.2012.09.011.

Hoepner, A., Oikonomou, I., Scholtens, B. and Schröder, M. (2016). The Effects of Corporate and Country Sustainability Characteristics on The Cost of Debt: An International Investigation. Journal of Business Finance and Accounting, 43(1-2), 158-190. doi:10.1111/jbfa.12183.

Holmstrom, B. (1989). Agency Costs and Innovation. Journal of Economic Behavior and Organization, 12(3), 305-327.

Hong, H. and Kacperczyk, M., (2009). The price of sin: The effects of social norms on markets. Journal of Financial Economics, 93(1), 15-36.

Horváthová, E. (2010). Does Environmental Performance Affect Financial Performance? A MetaAnalysis. Ecological Economics, 70(1), 52-59. doi:10.1016/j.ecolecon.2010.04.004. 
Horváthová, E. (2012). The impact of environmental performance on firm performance: Shortterm costs and long-term benefits?. Ecological Economics, 84, 91-97. doi:10.1016/j.ecolecon.2012.10.001.

Hsu, K.T. (2012). The Advertising Effects of Corporate Social Responsibility on Corporate Reputation and Brand Equity: Evidence from the Life Insurance Industry in Taiwan. Journal of Business Ethics, 109(2), 189-201. doi:10.1007/s10551-011-1118 0.

Huberman, G. and Regev, T. (2001). Contagious speculation and a cure for cancer: A nonevent that made stock prices soar. Journal of Finance, 56(1), 387-396. doi:10.1111/0022-1082.00330.

Ims, K.J., Pedersen, L.J.T. and Zsolnai, L. J. (2014). How economic incentives may destroy social, ecological and existential values: the case of execute compensation. Journal of Business Ethics, 123(2), 353-360.

Institute for Mergers, Acquisitions, and Alliances (IMAA), (2017). M\&A US - Mergers and Acquisitions in the United

Ioannou, I., and Serafeim, G. (2014). The impact of corporate social responsibility on investment recommendations: Analysts' perceptions and shifting institutional logics. Strategic Management Journal, 36(7), 1053-1081. doi:10.1002/smj.2268

Ioannou, I. and Serafeim, G, (2019). The Consequences of Mandatory Corporate Sustainability Reporting. The Oxford Handbook of Corporate Social Responsibility: Psychological and Organizational Perspectives. DOI:10.1093/oxfordhb/9780198802280.013.20

Jacobs, B.W., Singhal, V.R. and Subramanian, R. (2010). An empirical investigation of environmental performance and the market value of the firm. Journal of Operations Management, 28(5), 430-441. doi:10.1016/j.jom.2010.01.001. 
Jain, B. A., and Kini, O. (2000). Does the Presence of Venture Capitalists Improve the Survival Profile of IPO Firms?. Journal of Business Finance Accounting, 27(9\&10), 1139-1183. doi:10.1111/1468-5957.00350.

Jain, B.A., and Martin Jr., (2005). The association between audit quality and post-IPO performance: a survival analysis approach. Rev. Account. Financ. 4 (4), 50-75.

Jain, Bharat \& Kini, Omesh. (2008). The Impact of Strategic Investment Choices on Post-Issue Operating Performance and Survival of US IPO Firms. Journal of Business Finance \& Accounting, 35, 459-490. 10.1111/j.1468-5957.2007.02072.x.

Jarrell, G., and Peltzman, S. (1985). The impact of product recalls on the wealth of sellers. Journal of Political Economy, 93(3), 512-536.

Jenkinson, T., and Ljungqvist, A., (2001). In: n. Edition (Ed.), Going Public-The Theory and Evidence on how Companies Raise Equity Finance. Oxford University Press, Oxford.

Jo, H. and Harjoto, M.A. (2011). Corporate Governance and Firm Value: The Impact of Corporate Social Responsibility. Journal of Business Ethics, 103(3), 351-383.

doi:10.1007/s10551-011-0869-y.

Jo, H and Na, H (2012). Does CSR reduce firm risk? Evidence from controversial industry sectors. J Bus Ethics, 110, 441-456.

Johnstone, N. and Labonne, J. (2009). Why do manufacturing facilities introduce environmental management systems? Improving and/or signaling performance. Ecological Economics, 68(3), 719-730. doi: 10.1016/j.ecolecon.2008.06.003.

Judd, E. (1990). Investing with a Social Conscience, Pharos Books, New York.

Judge, W.Q. and Douglas, T.J. (1998). Performance Implications of Incorporating Natural Environmental Issues into the Strategic Planning Process: An Empirical Assessment. Journal of Management Studies, 35(2), 241-262. doi:10.1111/1467-6486.00092. 
Junior, R.M., Best, P.J. and Cotter, J. (2014). Sustainability Reporting and Assurance: A Historical Analysis on a World-Wide Phenomenon. Journal of Business Ethics, 120(1), 1-11.

Kacperczyk, A., (2009). With greater power comes greater responsibility? Takeover protection and corporate attention to stakeholders. Strategic Management Journal, 30(3), 261-285.

Kaiser, L. (2019). ESG Integration: Value, Growth and Momentum. SSRN Electronic Journal. https://ssrn.com/abstract=2993843 or http://dx.doi.org/10.2139/ssrn.2993843.

Kalkan, A., Bozkurt, O. and Arman, M. (2014). The Impacts of Intellectual Capital, Innovation and Organizational Strategy on Firm Performance. Procedia - Social and Behavioral Sciences, 150. doi:700-707. 10.1016/j.sbspro.2014.09.025.

Kang, J., and Kim, Y. H. (2013). The impact of media on corporate social responsibility. Available at SSRN 2287002.

Karpoff, J., and Lott, J. (1993). The reputational penalty firms bear from committing criminal fraud. Journal of Law and Economics, 36, 757-802.

Kempf, A. and Osthoff, P., (2007). The effect of socially re- sponsible investing on portfolio performance. European Financial Management, 13(5), 908-922.

Kim, Y., Li, H., and Li, S. (2014). Corporate social responsibility and stock price crash risk. Journal of Banking and Finance, 43, 1-13.

Kinder, P.D., Lydenberg, S.D. and Domini, A.L. (1993). Investing for Good: Making Money While Being Socially Responsible. Harper Collins, New York.

King, A. and Lenox, M. (2002). Exploring the locus of profitable pollution reduction. Management Science, 48(2), 289-299. doi:10.1287/mnsc.48.2.289.258.

King, B. G. and Soule, S. A. (2007). Social movements as extra- institutional entrepreneurs: The effect of protests on stock price returns. Administrative Science Quarterly, 52, 413-442. 
Klassen, R.D. and McLaughlin, C.P. (1996). The impact of environmental management on firm performance. Management Science, 42(8), 1199-1214. doi:10.1287/mnsc.42.8.1199.

Klassen, R.D. and Whybark, D.C. (1999). The impact of environmental technologies on manufacturing performance. Academy of Management Journal, 42(6), 599-615. doi:10.2307/256982.

Kleinknecht, A., Van Montfort, K. and Brouwer, E. (2002). The Non-Trivial Choice between Innovation Indicators. Economics of Innovation and New Technology, 11(2), 109-121. doi:10.1080/10438590210899.

Kleinknecht, A. and Oostendorp, R. (2002). R\&D and export performance: Taking account of simultaneity, In: Kleinknecht, A., and P. Mohnen (eds.), Innovation and firm performance. Econometric explorations of survey data, Basingstoke, UK: Palgrave, 310-320.

Kogan, L., Papanikolaou, D., Seru, A. and Stoffman, N. (2017). Technological Innovation, Resource Allocation, and Growth. The Quarterly Journal of Economics, 132(2), 665-712. doi:10.1093/qje/qjw040.

Konar, S., and Cohen, M., (2001). Does the market value environmental performance?. Review of Economics and Statistics, 83(2), 281-289.

Kotchen, M. and Moon, J., (2012). Corporate social responsibility for irresponsibility. Journal of Economic Analysis and Policy, 12(1), 1-23.

Krasnikov, A., Mishra, S. and Orozco, D. (2009). Evaluating the Financial Impact of Branding Using Trademarks: A Framework and Empirical Evidence. Journal of Marketing, 73(6), 154-166.

Krüger, P. (2015). Corporate goodness and shareholder wealth. Journal of Financial Economics, 115(2), 304-329. doi:10.1016/j.jfineco.2014.09.008. 
Laasch, O. and Conaway, R. (2015). Principles of Responsible Management: Glocal Sustainability, Responsibility, Ethics. Cengage, ISBN-13: 978-1285080260

Landes, W.M. and Posner, R.A. (1987). Trademark Law: An Economic Perspective. Journal of Law and Economics, 30(2), 265-309. http://www.jstor.org/stable/725498.

Landier, A., and Nair, V. B., (2009). Investing for Change: Profit from Responsible Investment. Oxford University Press, Oxford

Lang, P. (1996). Ethical Investment: A Saver's Guide, Jon Carpenter Publishing, Charlbury, Oxfordshire).

LeClere, M.J., (2000). The occurrence and timing of events: survival analysis applied to a study of financial distress. J. Account. Lit, 19, 158-189.

Letza, S., Sun, X. and Kirkbride, J. (2004). Shareholding versus stakeholding: A critical review of corporate governance. Corporate Governance: An International Review, 12(3), 242-262. doi:10.1111/j.1467-8683.2004.00367.x.

Li, F. (2008). Annual report readability, current earnings, and earnings persistence. Journal of Accounting and Economics, 45(2-3), 221-247. doi:10.1016/j.jacceco.2008.02.003.

Ling, A., Forrest, S., Lynch, M., and Fox, M. (2007). Global Food \& Beverages: Integrating ESG. Goldman Sachs: New York, NY, USA.

Lokuwaduge, C.S.D.S., and Heenetigala, K. (2017). Integrating Environmental, Social and Governance (ESG) Disclosure for a Sustainable Development: An Australian Study. Business Strategy and the Environment, 26(4), 438-450. doi:10.1002/bse.1927.

Louche, C. (2004). Ethical Investment: processes and mechanisms of institutionalization in the Netherlands, 1990-2002, PhD dissertation, Erasmus University Rotterdam: Available at: 
https://ep.eur.nl/retrieve/3259/ESM-dissertation-3003.pdf. Rotterdam: Optima Grafische Communicatie.

Louche, C. and Lydenberg, S. (2006). Socially responsible investment: differences between Europe and United States. Vlerick Leuven Gent Management School Working Paper Series 200622, Vlerick Leuven Gent Management School.

Lowry, R.P. (1993). Good Money - A Guide to Profitable Social Investing in the '90s. W.W. Norton, New York.

Lulewicz-Sas, A. and Kilon, J. (2014). Analysis of the effectiveness of socially responsible investing funds in Poland, Economics and Management, 19(4). 338-345. doi:10.1016/j.sbspro.2014.11.170.

Luo X, and Bhattacharya, CB (2009). The debate over doing good: corporate social performance, strategic marketing levers, and firm-idiosyncratic risk. J Market, 73, 198-213.

Lustig, H., Syverson, C. and Van Nieuwerburgh, S. (2011). Technological change and the growing inequality in managerial compensation. Journal of Financial Economics, 99(3), 601-627. doi:10.1016/j.jfineco.2010.09.007.

Malik, M.. (2014). Value-Enhancing Capabilities of CSR: A Brief Review of Contemporary Literature. Journal of Business Ethics, 127. doi: 10.1007/s10551-014-2051-9.

Manetti, G. and Becatti, L. (2009). Assurance services for sustainability reports: standards and empirical evidence. Journal of Business Ethics, 87(1), 289-298.

Margolis, J.D. and Walsh, J.P. (2003). Misery Loves Companies: Rethinking Social Initiatives by Business. Administrative Science Quarterly, 48(2), 268-305. doi:10.2307/3556659. 
Margolis, J., Elfenbein, H. and Walsh, J. (2009). Does it Pay to Be Good...And Does it Matter? A Meta-Analysis of the Relationship between Corporate Social and Financial Performance. SSRN Electronic Journal. doi:10.2139/ssrn.1866371.

Martin, J. (1986). Happy Returns for Do-gooders. Financial World, 32-33.

Maskus, K.E. and Penubarti, M. (1995). How trade-related are intellectual property rights?. Journal of International Economics, 39(3-4), 227-248. doi:10.1016/0022-1996(95)01377-8.

McGuire, J. B., Sundgren, A. and Schneeweis, T. (1988). Corporate Social Responsibility And Firm Financial Performance. Academy of Management Journal, 31(4), 854-872. doi:10.2307/256342

McWilliams, A. and Siegel, D. (2001). Corporate social responsibility: a theory of the firm perspective. Academy of Management Review, 26 (1), 117-127.

McWilliams, A., Siegel, D., and Wright, PM. (2006). Corporate social responsibility: strategic implications. Journal of Management Studies, 43(1), 1-18. doi:10.1111/j.14676486.2006.00580.x

Melnyk, S.A., Sroufe, R.P. and Calantone, R. (2003). Assessing the impact of environmental management systems on corporate and environmental performance. J. Oper. Manag, 21(3), 329351.

Mercer (2007). The language of responsible investment: An industry guide to key terms and organisations. Mercer Investment Consulting, London.

Mervelskemper, L. and Streit, D. (2016). Enhancing Market Valuation of ESG Performance: Is Integrated Reporting Keeping its Promise?. Business Strategy and the Environment. doi: 10.1002/bse. 1935

Miller, A.J. (1991). Socially Responsible Investing: How to Invest with Your Conscience. New York Institute of Finance, New York. 
Miller, D.J., Fern, M.J. and Cardinal, L.B. (2007). The use of knowledge for technological innovation within diversified firms. Academy of Management Journal, 50(2), 308-326. doi:10.5465/amj.2007.24634437.

Mitchell, M. (1989). The impact of external parties on brand-name capital: The 1982 tylenol poisonings and subsequent cases. Economic Inquiry, 27(4), 601-18.

Monks, R.A. (2002). The SRI Advantage. Introduction in P. Camejo (ed.), New Society Publishers, Gabriola Island, BC, pp. xiii-xix.

Moon, J. (2002). The Social Responsibility of Business and New Governance. Gov. Oppos., 37(3), 385-408.

Moore, C. and Gino, F. (2015). Approach, ability, aftermath: A psychological process framework of unethical behavior at work. The Academy of Management Annals, 9(1), 235-289.

Morioka, S.N. and Carvalho, M.M. (2016). A systematic literature review towards a conceptual framework for integrating sustainability performance into business. Journal of Cleaner Production, 136, 134-146. doi:10.1016/j.jclepro.2016.01.104.

Moskowitz, M. (1973). Why ‘Good Guy’ Funds have Flopped. New York Times Sunday.

Nehrt, C. (1998). Maintainability of first mover advantages when environmental regulations differ between countries. Academy of Management Review, 23(1), 77-97. doi:10.5465/AMR.1998.192962.

Nelson, R.R. and Winter, S.G. (1982). An Evolutionary Theory of Economic Change,Cambridge, Mass.: Belknap Press of Harvard University Press. 
Ng, A.C. and Rezaee, Z. (2015). Business sustainability performance and cost of equity capital. Journal of Corporate Finance, 34, 128-149. doi:10.1016/j.jcorpfin.2015.08.003.

Nidumolu, R., Prahalad, C. K., and Rangaswami, M. R. (2009). Why Sustainability Is Now the Key Driver of Innovation. Harvard Business Review, (9), 57-64. doi: 10.1109/emr.2015.7123233.

Nilolaeva, R. and Bicho, M. (2011). The role of institutional and reputational factors in the voluntary adoption of corporate social responsibility reporting standards. Journal of the Academy of Marketing Science, 39, 136-157.

Oikonomou, I., Brooks, C., and Pavelin, S. (2012). The impact of corporate social performance on financial risk and utility: A longitudinal analysis. Financial Management, 41(2), 483-515.

Orlitzky M, and Benjamin, JD. (2001) Corporate social performance and firm risk: a meta-analytic review. Business and Society, 40, 369-396.

Palmer, K., Oates, W.E. and Portey, P.R. (1995). Tightening environmental standards: the benefitcost or the no-cost paradigm?. Journal of Economic Perspectives, 9(4), 119-132.

Park A, and Ravenel, C. (2013). Bloomberg LP Integrating Sustainability into Capital Markets: Bloomberg LP And ESG's Quantitative Legitimacy, Journal of Applied Corporate Finance, 25(3), 62- 69.

Pasewark, W.R. and Riley, M.E. (2010). It's a matter of principle: the role of personal values in investment decisions. Journal of Business Ethics, 93(2), 237-253.

Peters, R.H. and Taylor, L.A. (2016). Intangible capital and the investment-q relation. Journal of Financial Economics, 123(2), 251-272. doi:10.1016/j.jfineco.2016.03.011.

Pienitz, R. and Vincent, W. F. (2000). Effect of climate change relative to ozone depletion on UV exposure in subarctic lakes. Nature, 404(6777), 484-487. 
Porter, M.E. (1985). Competitive strategy. New York: The Free Press.

Porter, M.E. (1991). Towards a dynamic theory of strategy. Strateg. Manag. J., 12 (Special Issue: Fundamental Research Issues in Strategy and Economics), 95-117.

Porter, M.E. and Van Der Linde, C. (1995a). Green and competitive: Ending the stalemate. Harvard Business Review, 120-134.

Porter ME, van der Linde C. (1995b). Toward a new conception of the environmentcompetitiveness relationship. Journal of Economic Perspectives 9(4): 97-118. DOI:10.1257/jep.9.4.97

Porter, ME and Kramer, MR. (2006). Strategy and society: the link between competitive advantage and corporate social responsibility. Harvard Business Review, 84(12), 78-92.

Porter, M. and Kramer, M. (2011). The Big Idea: Creating Shared Value. How to Reinvent Capitalism - and Unleash a Wave of Innovation and Growth. Harvard Business Review, 89. 6277.

Powers, C.W. (1971) Social Responsibility and Investments. Abingdon Press, Nashville.

Prescott, E.C. and Visscher, M. (1980). Organization Capital Michael Visscher. The Journal of Political Economy, 88(3), 446-461.

Purvis, B., Mao, Y. and Robinson, D. (2019). Three pillars of sustainability: in search of conceptual origins. Sustain Sci, 14, 681-695. doi:10.1007/s11625-018-0627-5

Renneboog, L., Horst, J.T. and Zhang, C. (2008). Socially Responsible Investments: Institutional Aspects, Performance and Investor Behavior, Journal of Banking and Finance, 32(9), 1723-1742. doi:10.1016/j.jbankfin.2007.12.039. 
Rennings, K., Schroder, M., and Ziegler, A. (2007). The effect of environmental and social performance on the stock performance of European corporations. Environmental and Resource Economics, 37(4), 661-680.

Reverte, C. (2009). Determinants of corporate social responsibility disclosure ratings by Spanish listed firms. Journal of Business Ethics, 88(2), 351-366.

Reverte, C. (2012). The Impact of Better Corporate Social Responsibility Disclosure on the Cost of Equity Capital. Corporate Social Responsibility and Environmental Management, 19(5), 253272. doi:10.1002/csr.273.

Richardson, B.J. (2009). Keeping Ethical Investment Ethical: Regulatory Issues for Investing for Sustainability. Journal of Business Ethics, 87(4), 555-572.

Rindova, V.P. and Fombrun, C.J. (1999). Constructing competitive advantage: the role of firmconstituent interactions. Strategic management journa,. 20(8), 691-710.

Ritter, J. R. (2003). Differences between European and American IPO Markets. European Financial Management, 9(4), 421-434. doi:10.1111/1468-036x.00230.

Rosenberg, N. (1981). How Exogenous is Science? in Inside the Black Box: Technology and Economics, edited by Rosenberg, Cambridge University Press, New York.

Rosenbaum, P.R. and Rubin, D. B. (1983). The central role of the propensity score in observational studies for causal effects. Biometrica, 70(1), 41-55. doi:10.1017/CBO9780511810725.016.

Rosett, J. and Smith, R., (2014a). Are public equity markets declining in impor- tance?. Journal of Applied Finance, 24, 6-13.

Rosett, J. and Smith, R., (2014b.) Public equity markets: special panel session from the 2013 FMA annual meeting. Journal of Applied Finance, 24, 14-35. 
Russo, M.V. and Fouts, P.A. (1997). A resource-based perspective on corporate environmental performance and profitability. Academy of Management Journal, 40(3), 534-559. doi:10.2307/257052.

Sacconi, L. (2006). A Social Contract Account for CSR as Extended Model of Corporate Governance (I): Rational Bargaining and Justification. Journal of Business Ethics, 68(Special Issue on Social Contract Theories in Business Ethics), 259-281.

Sandberg, J., Juravle, C., Hedesström, T.M. and Hamilton, I. (2009). The Heterogeneity of Socially Responsible Investment, Journal of Business Ethics, 87(4), 519-533.

Sandner, P.G. and Block, J. (2011). The market value of R\&D, patents, and trademarks, Research Policy, 40(7), 969-985. doi:10.1016/j.respol.2011.04.004.

Sankar, S. and Bhattacharya, C.B. (2001). Doing Better? Social Lead Consumer Reactions Doing Corporate Responsibility. Journal of Marketing Research, 38(2), 225-243. doi:10.1509/jmkr.38.2.225.18838.

Schroder, M., (2007). Is there a difference? The performance characteristics of SRI equity indices. Journal of Business Finance and Accounting, 34 (1,2), 331-348.

Schueth, S.J. (2003). Socially Responsible Investing in the United States. Journal of Business Ethics, 43(3), 189-94.

Schuler, D., Rasche, A., Etzion, D., and Newton, L. (2017) Corporate Sustainability Management and Environmental Ethics. Business Ethics Quarterly, 27(2), 213-237. doi:10.1017/beq.2016.80.

Schumpeter, JA. (1934). The Theory of Economic Development: An Inquiry into Profits, Capital, Credit, Interest, and the Business Cycle. Transaction Publishers: New Brunswick, NJ.

Schumpeter, J.A. (1942). Capitalism, Socialism and Democracy. Harper and Row, New York, 36, $132-145$. 
Schwartz, M.S. and Carroll, A.B. (2003). Corporate Social Responsibility: A Three Domain Approach. Business Ethics Quarterly, 13(4), 503-530.

Searcy, C. and Elkhawas, D. (2012). Corporate sustainability ratings: an investigation into how corporations use the Dow Jones Sustainability Index. Journal of Cleaner Production, 35, 79-92.

Sen, S., Gürhan-Canli, Z. and Morwitz, V. (2001). Withholding Consumption: A Social Dilemma Perspective on Consumer Boycotts. Journal of Consumer Research, 28(3), 399-417. doi:10.1086/323729.

Servaes, H., Tamayo, A., 2013. The impact of corporate social responsibility on firm value: The role of customer awareness. Management Science, 59(5), 1045-1061.

Sharfman, M.P. and Fernando, C.S. (2008). Environmental risk management and the cost of capital. Strategic Management Journal, 29(6), 569-592. doi:10.1002/smj.678.

Sharma, S. and Vredenburg, H. (1998). Proactive corporate environmental strategy and the development of competitively valuable organizational capabilities. Strategic Management Journal, 19(8), 729-753.

Sharpe, WF. (1964). Capital asset prices: a theory of market equilibrium under conditions of risk. J Financ, 19,425-442.

Shumway, T. (2001). Forecasting bankruptcy more accurately: A simple hazard model.Journal of Business, 74(1), 101-124.

Sneddon, C., Howarth, R.B. and Norgaard, R.B. (2006). Sustainable Development in a PostBrundtland World, Ecological Economics, 57(2), 253 - 268.

Shaukat, A., Qiu, Y. and Trojanowski, G. (2016). Board attributes, corporate social responsibility strategy, and corporate environmental and social performance. J. Bus. Ethics, 135, 569-585. 
Simon, J.G., Powers, C.W. and Gunnemann, J.P. (1972). The Ethical Investor: Universities and Corporate Responsibility, Yale University Press, London.

Sparkes, R. (1995). The Ethical Investor, Harper Collins, London.

Sparkes, R. (2001). Ethical Investment: Whose Ethics, Which Investment?. Business Ethics: A European Review, 10(3), 194 - 205. doi:10.1111/1467-8608.00233.

Sparkes, R. (2002). Socially responsible investment: a global revolution, Wiley Publication.

Sparkes, R. (2003). Socially responsible investment: A global revolution. John Wiley and Sons, Chichester, UK.

Sparkes, R. and Cowton, C.J. (2004). The maturing of socially responsible investment: a review of the developing link with corporate social responsibility. Journal of Business Ethics, 52(1), 4557.

Starks, L.T. (2009). EFA Keynote Speech: Corporate Governance and Corporate Social Responsibility: What Do Investors Care about? What Should Investors Care about? Financial Review, 44(4), 461-468. doi:10.1111/j.1540-6288.2009.00225.x.

Statman, M. and Glushkov, D., (2009). The wages of social responsibility. Financial Analysts Journal 65 (4), 774- 800.

Stern, N. (2008). The economics of climate change. The American Economic Review, 98(2), 1-37. doi:10.4324/9780203495780.

Stubbs, W. and Cocklin, C. (2008). Conceptualizing a Sustainability Business Model. Organization \& Environment, 21(2), 103-127. doi:10.1177/1086026608318042.

Sullivan, R. and Mackenzie, C. (2006) Responsible Investment. Greenleaf Publishing, Sheffield, UK. 
SustainAbility (2018). Rate the Raters 2018: Ratings Revisited. New York: SustainAbility.

Syverson, C. (2011). What determines productivity. Journal of Economic Literature, 49(2), 326365. doi:10.1257/jel.49.2.326.

Triguero, A., Moreno-Mondéjar, L. and Davia, M.A. (2013). Drivers of different types of ecoinnovation in European SMEs. Ecological Economics, 92, 25-33.

Turban, D.B. and Greening, D.W. (1996). Corporate social performance and organizational attractiveness to prospective employees. Academy of Management Journal, 40, 658-672. doi:10.2307/257057.

Umlas, E. (2008). The Global Expansion of SRI: Facing Challenges, Meeting Potential. Development and Change, 39(6), 1019-1036.

Useche, D. (2014). Are patents signals for the IPO market? An EU-US comparison for the software industry. Research Policy, 43(8), 1299-1311. doi:10.1016/j.respol.2014.04.004.

Utterback, J. M. and Abernathy, W. J. (1975). A dynamic model of process and product innovation. Omega, 3(6), 639-656. doi:10.1016/0305-0483(75)90068-7.

Van Beurden, P. and Gössling, T. (2008). The worth of values-A literature review on the relation between corporate social and financial performance. J. Bus. Ethics, 82(2), 407-424. www.jstor.org/stable/25482299.

Van Duuren, E., Plantinga, A., and Scholtens, B. (2016). ESG integration and the investment management process: Fundamental investing reinvented. Journal of Business Ethics, 138(3), 525533.

Vanhamme, J., and Grobben, B. (2009). "Too Good to be True!'. The effectiveness of CSR history in countering negative publicity. Journal of Business Ethics, 85(2), 273-283. 
Van Marrewijk, M. (2003). Concepts and definitions of CSR and corporate sustainability: between agency and communion. J. Bus. Ethics, 44(2), 95-105. doi:10.1023/A:1023331212247.

Venturelli, A., Caputo, F., Cosma, S., Leopizzi, R. and Pizzi, S. (2017). Directive 2014/95/EU: Are Italian Companies Already Compliant?. Sustainability, 9(8), 1-19.

Verrecchia, R. E. (1983). Discretionary disclosure. Journal of Accounting and Economics, 5, 179194. doi:10.1016/0165-4101(83)90011-3

Vogel, D. (1978). Lobbying the corporation - Citizen challenges to business authority. New York: basic Books, Inc.

Waddock, S.A. and Graves, S.B. (1997). The corporate social performance-financial performance link. Strategic Management Journal., 18(4), 303-319. https://www.jstor.org/stable/3088143

Waddock, S. (2004). Creating Corporate Accountability: Foundational Principles to Make Corporate Citizenship Real. Journal of Business Ethics, 50(4), 313-327. doi:10.1023/B:BUSI.0000025080.77652.a3.

Wadhwa, A. and Kotha, S. (2006). Knowledge creation through external venturing: Evidence from the telecommunications equipment manufacturing industry. Academy of Management Journal, 49(4), 819-835. doi:10.5465/AMJ.2006.22083132.

Wagner, M. (2010). The role of corporate sustainability performance for economic performance: A firm-level analysis of moderation effects. Ecological Economics, 69(7), 1553-1560. doi:10.1016/j.ecolecon.2010.02.017.

Wang, L. and Lin, L. (2007). A methodological framework for the triple bottom line accounting and management of industry enterprises. International Journal of Production Research, 45(5), 1063-1088. doi:10.1080/00207540600635136. 
Wang, H., Choi, J. and Li, J. (2008). Too little or too much? Untangling the relationship between corporate philanthropy and firm financial performance. Organization Science, 19(1), 143-159. doi:10.1287/orsc. 1070.0271

Ward, S. (1991). Socially Responsible Investment. Directory of Social Change, London.

Weber O. (2014). Environmental, Social and Governance Reporting in China. Business Strategy and the Environment, 23(5), 303-317.

Whelan, T. and Fink, C. (2016). The comprehensive business case for sustainability. Harvard Business Review, 10.

Whelan, T. and Sacco, R.K. (2019). Research: Actually, Consumers Do Buy Sustainable Products. Harvard Business Review.

Who cares wins (2004). Global Compact Report. Available at: https://www.scribd.com/fullscreen/16876740?access_key=key-16pe23pd759qalbnx2pv (Accessed: 12 June 2020).

World Commission on Environment and Development (1987). Our Common Future. Oxford: Oxford University Press.

Yadav, P.L., Han, S.H. and Rho, J. J. (2016). Impact of environmental performance on firm value for sustainable investment: evidence from large US firms. Business Strategy and the Environment, 25(6), 402-420.

Yoon, Y., Gurhan-Canli, Z., \& Schwarz, N. (2006). The effect of corporate social responsibility (CSR) activities on companies with bad reputations. Journal of Consumer Psychology, 16(4), 377390.

Zhao, Z. (2004). Using Matching To Estimate Treatment Effects. The Review of Economics and Statistics, 86(1), 91-107. 
Ziegler, A. and Schröder, M. (2010). What determines the inclusion in a sustainability stock index? A panel data analysis for european firms. Ecological Economics, 69(4), 848-856. 


\section{Appendix A (Chapter 3)}

Table 13 (A.1). Variable names and definitions

\begin{tabular}{ll}
\hline \multicolumn{1}{c}{ Variables } & \multicolumn{1}{c}{ Definition } \\
\hline Dependent Variables: & \\
$E S G$ & $\begin{array}{l}\text { Sustainability index that quantifies a company's performance to environmental, } \\
\text { social and governance matters } \\
\text { Sustainability component that quantifies a company's performance to } \\
\text { environmental } \\
\text { Sustainability component that quantifies a company's performance to social } \\
\text { Sustainability component that quantifies a company's performance to } \\
\text { governance }\end{array}$ \\
$S P$ &
\end{tabular}

Treatment Variables:

DummyR\&D

DummyPatents

Dummy variable set to 1 if firms $R \& D$ expenses are is over the sample average, else 0 .

DummyTrademarks

DummyKnowledgeCapital

DummyOrganization

Dummy variable set to 1 if firms patent activity is over the sample average, else 0 .

Dummy variable set to 1 if firms trademark activity is over the sample average, else 0.

Dummy variable set to 1 if firms knowledge capital is over the sample average, else 0 .

Dummy variable set to 1 if firms organization capital is over the sample average, else 0 .

\begin{tabular}{|c|c|}
\hline \multicolumn{2}{|l|}{ Control Variables: } \\
\hline Sales/Total assets & Firms' sales over total assets \\
\hline$($ Sales/Total assets $) 2$ & A quadratic term that indicates firms' sales over total assets \\
\hline Sales growth & The growth of firm's sales \\
\hline Firm Age & The number of years from the firm's initial incorporation date. \\
\hline Advertising & The natural log of Firms advertising expenses in millions of dollars \\
\hline TM/Sales & The number of trademarks of a firm share to total sales \\
\hline$R \& D /$ Total assets & $\begin{array}{l}\text { Firms research and development expenses spending in millions of dollars share } \\
\text { to total sales }\end{array}$ \\
\hline Patents/Total assets & The number of patents of a firm share to total assets. \\
\hline Intangible Capital/Total assets & $\begin{array}{l}\text { Firm's intangible capital share to total assets; It is estimated as the total } \\
\text { replacement cost of organization capital and knowledge capital and coming } \\
\text { from WRDS database (Peters and Taylor, 2016). }\end{array}$ \\
\hline Knowledge Capital/Total assets & $\begin{array}{l}\text { The replacement cost of knowledge capital share to total assets; Coming from } \\
\text { WRDS database (Peters and Taylor, 2016). }\end{array}$ \\
\hline Organization Capital/Total assets & $\begin{array}{l}\text { The replacement cost of knowledge capital share to total assets; Coming from } \\
\text { WRDS database (Peters and Taylor, 2016). }\end{array}$ \\
\hline$(T M / R \& D)$ & $\begin{array}{l}\text { The share of trademarks over research and development expenses, indicates } \\
\text { TM efficiency }\end{array}$ \\
\hline (Patents/R\&D) & $\begin{array}{l}\text { The share of patents over research and development expenses, indicates patent } \\
\text { efficiency }\end{array}$ \\
\hline Crisis & Dummy variable that takes the value of 1 for financial crisis period, else 0 . \\
\hline
\end{tabular}


Table 14 (A.2). Estimates of equation (3)

Table A2: Dependent variable is sustainability (ESG)

\begin{tabular}{|c|c|c|c|}
\hline VARIABLES & $\begin{array}{c}(1) \\
\text { ESG }\end{array}$ & $\begin{array}{c}(2) \\
\text { ESG }\end{array}$ & $\begin{array}{c}(3) \\
\text { ESG }\end{array}$ \\
\hline$\left(\right.$ Sales/Total assets) ${ }_{t-1}$ & $\begin{array}{c}0.889 * * * \\
(0.330)\end{array}$ & $\begin{array}{c}0.880 * * * \\
(0.330)\end{array}$ & $\begin{array}{c}0.882 * * * \\
(0.330)\end{array}$ \\
\hline$(\text { Sales/Total assets })_{t-1}^{2}$ & $\begin{array}{l}-0.054 \\
(0.059)\end{array}$ & $\begin{array}{l}-0.052 \\
(0.059)\end{array}$ & $\begin{array}{l}-0.052 \\
(0.059)\end{array}$ \\
\hline$(\text { Sales growth })_{t-1}$ & $\begin{array}{l}0.026^{*} \\
(0.015)\end{array}$ & $\begin{array}{l}0.026^{*} \\
(0.015)\end{array}$ & $\begin{array}{l}0.027 * \\
(0.015)\end{array}$ \\
\hline$(\text { FirmAge })_{t-1}$ & $\begin{array}{c}-0.067 * * * \\
(0.005)\end{array}$ & $\begin{array}{c}-0.067 * * * \\
(0.005)\end{array}$ & $\begin{array}{c}-0.067 * * * \\
(0.005)\end{array}$ \\
\hline Crisis & $\begin{array}{c}6.925 * * * \\
(0.504)\end{array}$ & $\begin{array}{c}6.904 * * * \\
(0.504)\end{array}$ & $\begin{array}{c}6.909 * * * \\
(0.505)\end{array}$ \\
\hline$(\text { Advertising })_{t-1}$ & $\begin{array}{c}-0.008 * * * \\
(0.001)\end{array}$ & $\begin{array}{c}-0.008 * * * \\
(0.001)\end{array}$ & $\begin{array}{c}-0.008 * * * \\
(0.001)\end{array}$ \\
\hline$(\text { Patents/Total assets })_{t-1}$ & $\begin{array}{c}0.124 * * * \\
(0.031)\end{array}$ & $\begin{array}{c}0.128 * * * \\
(0.033)\end{array}$ & $\begin{array}{c}0.127 * * * \\
(0.032)\end{array}$ \\
\hline$(\text { TM/Sales })_{t-1}$ & $\begin{array}{c}0.079 * * * \\
(0.019)\end{array}$ & $\begin{array}{c}0.075 * * * \\
(0.019)\end{array}$ & $\begin{array}{c}0.076 * * * \\
(0.019)\end{array}$ \\
\hline$(T M / R \& D)_{t-1}$ & & $\begin{array}{c}0.318 * * * \\
(0.091)\end{array}$ & $\begin{array}{c}0.271 * * * \\
(0.097)\end{array}$ \\
\hline$(\text { Patents } / R \& D)_{t-1}$ & $\begin{array}{c}0.145^{* *} \\
(0.059)\end{array}$ & & $\begin{array}{c}0.045 \\
(0.080)\end{array}$ \\
\hline Observations & 6,802 & 6,802 & 6,802 \\
\hline$R$-squared & 0.289 & 0.289 & 0.289 \\
\hline Year FE & YES & YES & YES \\
\hline Sector FE & YES & YES & YES \\
\hline ROBUST & YES & YES & YES \\
\hline
\end{tabular}

Robust standard errors in parentheses $* * * \mathrm{p}<0.01, * * \mathrm{p}<0.05, * \mathrm{p}<0.1$ 
Figure 12 (A.1). Average R\&D, 2007 - 2016

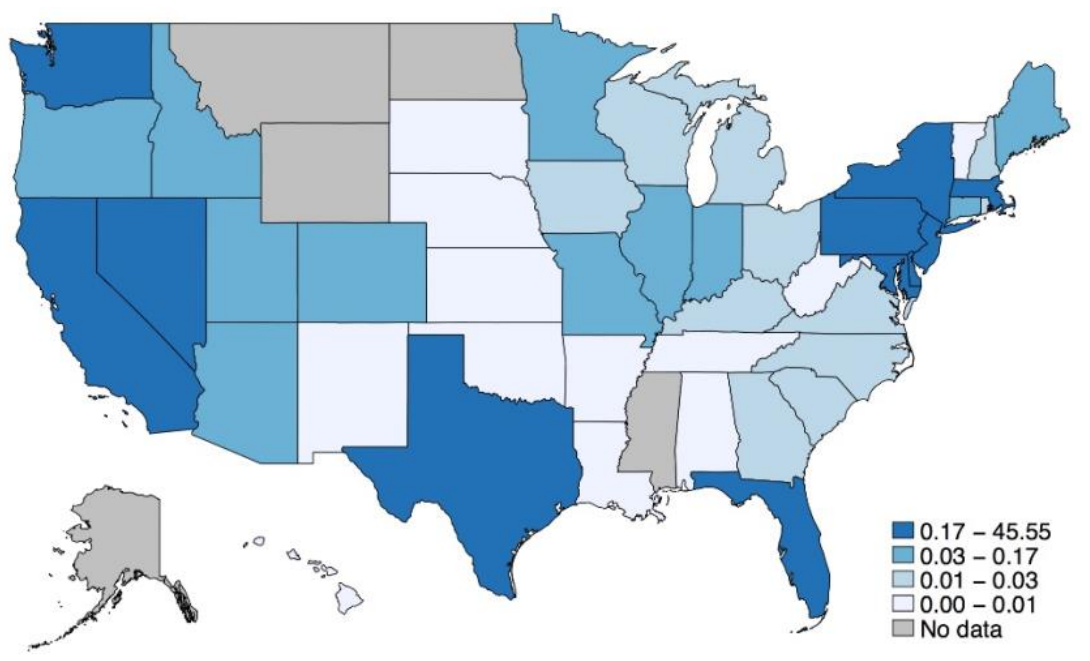

Figure 13 (A.2). Average Patents, 2007 - 2016

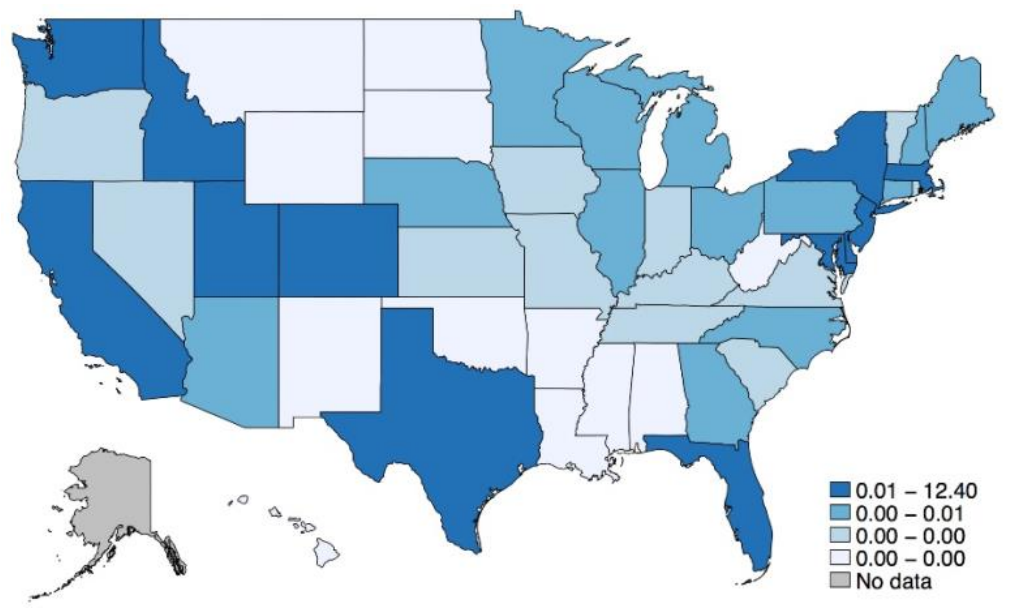


Figure 14 (A.3). Average Trademarks, 2007 - 2016

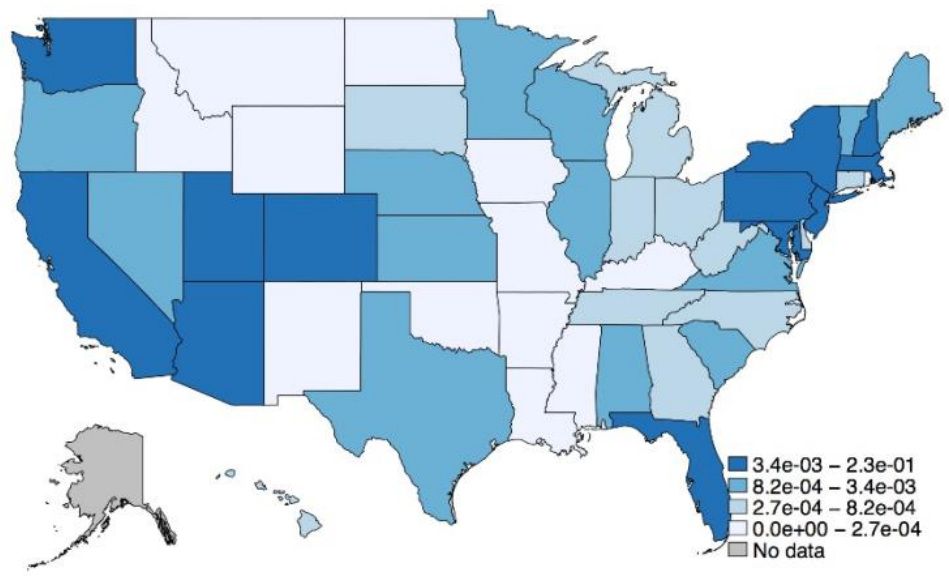




\section{Appendix B (Chapter 4)}

Table 15 (B.1). Variable names and definitions.

\begin{tabular}{|c|c|}
\hline Variables & Definition \\
\hline \multicolumn{2}{|l|}{ ESG Variables } \\
\hline$R R I$ & $\begin{array}{l}\text { RRI index that quantifies a company's exposure to environmental, social, and } \\
\text { governance issues }\end{array}$ \\
\hline EP issues & An index that quantifies a company's exposure to environmental issues \\
\hline SP issues & An index that quantifies a company's exposure to social issues \\
\hline GP issues & An index that quantifies a company's exposure to governance issues \\
\hline ESG issues & $\begin{array}{l}\text { A dummy variable set to } 1 \text { if a firm was exposed to environmental, social, and } \\
\text { governance issues }\end{array}$ \\
\hline \multicolumn{2}{|l|}{ Control Variables: } \\
\hline $\log ($ Sales $)$ & Natural $\log$ of a firm's sales \\
\hline$(\log (\text { Sales }))^{2}$ & Natural log of sales quadratic term \\
\hline Log (Sales growth) & Log of a firm's sales growth \\
\hline Log (Firm Age) & Log of the number of years from a firm's initial incorporation date. \\
\hline Log (Advertising) & Natural $\log$ of a firm's advertising expenses \\
\hline $\log (T M)$ & Natural log of a firm's trademarks \\
\hline Log (Patents) & Natural log of a firm's patents \\
\hline Return on Equity & A firm's return on equity \\
\hline Crisis & Dummy variable that took the value of 1 for a financial crisis period; otherwise 0 . \\
\hline
\end{tabular}

Table 16 (B.2). Estimates of firms M\&A probability with respect to ESG issues and its three major components namely environmental (EP) issues, social (SP)issues and governance (GP) issues on firms M\&A probability.

\section{(1)} Successful merger
(2) Successful merger
(3) Successful merger
(4) Successful merger

\begin{tabular}{|c|c|c|c|c|}
\hline VARIABLES & Successful merger & Successful merger & Successful merger & Successful mer \\
\hline ESG issues & $\begin{array}{c}0.013 * * * \\
(0.003)\end{array}$ & & & \\
\hline $\begin{array}{l}\text { Governance }(G P) \\
\text { issues }\end{array}$ & & $\begin{array}{c}0.294 * * * \\
(0.061)\end{array}$ & & \\
\hline $\begin{array}{l}\text { Environmental } \\
(E P) \text { issues }\end{array}$ & & & $\begin{array}{l}0.051 \\
(0.062)\end{array}$ & \\
\hline Social (SP) issues & & & & $\begin{array}{c}0.031 \\
(0.059)\end{array}$ \\
\hline $\log ($ Sales $)$ & $\begin{array}{c}0.280 * * * \\
(0.100)\end{array}$ & $\begin{array}{c}0.252 * * * \\
(0.089)\end{array}$ & $\begin{array}{c}0.216^{* *} \\
(0.085)\end{array}$ & $\begin{array}{c}0.213 * * \\
(0.084)\end{array}$ \\
\hline$(\log (\text { Sales }))^{2}$ & $\begin{array}{c}-0.023 * * * \\
(0.007)\end{array}$ & $\begin{array}{c}-0.020 * * * \\
(0.006)\end{array}$ & $\begin{array}{c}-0.017 * * * \\
(0.006)\end{array}$ & $\begin{array}{c}-0.016 * * * \\
(0.006)\end{array}$ \\
\hline Log (Sales growth) & -0.007 & -0.007 & -0.008 & -0.008 \\
\hline
\end{tabular}




\begin{tabular}{lcccc} 
& $(0.013)$ & $(0.012)$ & $(0.013)$ & $(0.013)$ \\
Log $($ FirmAge $)$ & 0.029 & 0.039 & 0.037 & 0.039 \\
& $(0.030)$ & $(0.031)$ & $(0.030)$ & $(0.030)$ \\
Log $($ Patents $)$ & -0.019 & -0.021 & -0.014 & -0.014 \\
& $(0.016)$ & $(0.016)$ & $(0.015)$ & $(0.015)$ \\
$\log (T M)$ & $-0.119^{* * *}$ & $-0.119^{* * *}$ & $-0.122^{* * *}$ & $-0.123^{* * *}$ \\
& $(0.044)$ & $(0.044)$ & $(0.044)$ & $(0.044)$ \\
Log (Advertising) & -0.011 & -0.011 & -0.007 & -0.007 \\
& $(0.011)$ & $(0.011)$ & $(0.011)$ & $(0.011)$ \\
Crisis & $0.870^{* * *}$ & $0.879^{* * *}$ & $0.753^{* * *}$ & $0.759^{* * *}$ \\
& $(0.223)$ & $(0.223)$ & $(0.224)$ & $(0.224)$ \\
Return on Equity & -0.012 & -0.011 & -0.011 & -0.011 \\
& $(0.016)$ & $(0.015)$ & $(0.015)$ & $(0.015)$ \\
Chi-square test & & & & 0.000 \\
probability & 0.000 & 0.000 & 0.000 & 11,337 \\
Observations & 11,337 & 11,337 & 11,337 & YES \\
Year FE & YES & YES & YES & \\
\hline
\end{tabular}

This table provides Probit regression estimations of the impact of ESG issues, on the probability of exiting the market through an M\&A. All the variables are defined in Table A1. The standard errors are shown in parentheses below the estimated coefficients. Robust standard errors are in parentheses. One, two, and three asterisks indicate statistical significance at the $10 \%, 5 \%$, and $1 \%$ levels, respectively. $* * * p<0.01, * * \mathrm{p}<0.05,{ }^{*} \mathrm{p}<0.1$ 